LA- -9041 Vol. 2

DE82 015037

\title{
Nondestructive Verification and Assay Systems for Spent Fuels
}

\section{Technical Appendixes}

D. D. Cobb

J. R. Phillips

M. P. Baker

G. E. Bosler

G. W. Eccleston

J. K. Halbig

S. L. Klein

S. F. Klosterbuer

H. O. Menlove

C. A. Ostenak

C. C. Thomas, Jr. 
APPENDIX A: SPENT-IUEL COMPOSITION: A COMPARISON

I. INTRODUCTION 2

II. DATA BASE 2

III. COMPARISON OF PREDICTED AND MEISURED SPENT-FUEL PARANETERS 2

IV. DISCUSSION 4

REFEREWCES

APPENDIX B: GE-MORRIS EXPERIMENTAL PROGRAH 6

I. INTRODUCTION 6

II. EXPERIMENTAL APPARATUS

III, EXPERIMENTAL RESULTS

A. Raproducibility 8

B. Angular Effect 10

C. Emplrical Correlations 15

D. Fiel Ansembly Geometry 16

E. Conclualons 16

APPENDIX C: BIBLIOGRAPHY ON SPENT-FUEL MEASUREMENTS

TO APRIL 2, 2981

APPENDIX D: IRRADIATED-FUEL CALCULATIONS

I. ISOTOPE PRODUCTION AND DEPLETION

II. NEUTRON SIGNALS

III. GAMHA-RAY SIGNAIS

REFERUNCES

APPUNDIX E: PULSKD-HEUTRON INTERROGATION TECHNIQUE FOR THE DETERMINATION OF THE FISSILE CONTENT OF SPENT-FUEL ASSMABLIES

I. INTRODUSTION

II. PRINCIPLS OF THE TECHNIOUE

A. Pulsed 14-MeV Neutron Generator 57

B. Nodulated 252 Cf Neutron Source $\quad 59$

C. Separations of F1ssile Urantum and Plutoniun Contents 59

REFERATCES

APPENDIX F: EXPERIHENTML PROGRAY AT LOS ALAMOS 62

I. EXPARTMENTAL FACILITIES AND EQUIPNENT 62

II. INITIAL CODE VALIDATION EXPERIMENTS 64

III. FUEL MATHIXI INYMTTORY

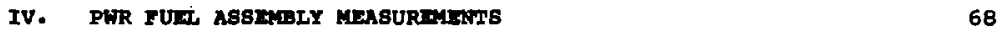

V. EXPERIMIATMI GOALS AND MEABURMULAT OBJECTIVES 
A-I. Spent-Fuel Data Base

A-II. Spent-Fuel Composition: Comparison of Predicted and Measured values

A-III. Spent-Puel Composition: Pcoled Comparions of Predicted and Meanured Values

B-I. Fuel Ansemblies Examined at GE-Morris Facility

B-II. Individual tuel Assemblies

B-III. Comparison of Measurements Using Limit Switches and Fixed Ponttion - Fuel Assembly B-C032

B-IV. Reproducibility of Heasurements for Various Fuel-Assembly Geonetries

B-V. Reproduclbllity of Measurements for standard Fuel Assembly B-c32

B-VI. Background keasurements

B-VII. Normalized Responees for Each of the Spent-Fuel Assemblies

B-VIII. Maximun Differences in the Measurements at the Four Corner rositians

B-IX. Individual Irradiation Historien of Fuel Assemblies 15

B-X.' Power Functione for PwR Measurewent: 16

D-I. Comparison of Measured and Calculated H. B. Robineon-2 Isotopic Ratios

D-II. Sources of Neutrone in Irradiated $\mathrm{VO}_{2}$ Material:

E-I. Delayed Neutron Fractions

F-I. Specifications for Matched 2.54-cm-dian 235U Proportional counter.

F-II. Comparison Between Bxperimental and Calculational Responses to a 252 cf souree for a Fiustion Chamber in Water

r-III. PWR Fuel Materials and component. 
D-1. Positioning mechanian for prototype verification and aceay oystem.

B-2. Relative ponition of the fuel asmembly and the detector tube.

B-3. Datector package uned in the GL-Morrie Field exercise.

B-4. De $(Y, n)$ detector that is censitive to only $h 1 g h-e n e r g y$ $(>1.66-\mathrm{HeV})$ ganan rays.

8-5. Spent-fuel measurement gysten installed in the GE-Horris unloading pool.

B-6. Relative neutron emisaton rates an function of the four corner positions for fuel ausemblies from Reactor $\mathrm{A}$.

B-7. Relative neutron enisulon rates an a function of the four corner poultione for fuel assemblies fron Reactor $B$.

B-8. Relative neutron eniseion rates ad a function of the four corner positions for fuel assemblies from Reactor $C$. 14

B-9. Relative neutron entseion rates as a function of the four corner postions for fuel as semblies from Ractor D.

8-10. Reactor core In which fuel assemblien C-032, C-056, and c-052 were irradiated.

B-11. Data from the three PWR data sets with the Individual power function. (best $f(t)$ and the collective results (dashed line).

B-12. Comparison of reaults from 15 by 15 (C056 and C052) fuel asenblies with 14 by 14 (CO20, DO46, and DOOL) fuel ansenblies.

D-1. Lightwater reactor production chaing for the traneuranic 1sotopes from $235 \mathrm{U}$ and $230 \mathrm{U}$ feed material.

D-2. Sensitivity of 235 to varlous reactor paraneters as a function of exposure.

$D-3$. Seneitivity of ${ }^{239} \mathrm{Pu}$ to varfous reactor parameters as a function of exposure.

D-4. Sensitivity of $241_{P u}$ to varlous reactor parametera as a function of exposure.

D-5. Senuitivity of total fialle material to varlous reactor paraneter: as a function of exposure.

D-6. Senuitivity of ${ }^{238} \mathrm{pu}$ to various reactor paraneters a a function of exponure.

D-7. Sensitivity of ${ }^{240} \mathrm{Pu}$ to various reactor paraneters as a function of exposure.

D-8. Seneitivity of 242pu to varlous reactor parameter. as a function of exposure.

D-9. Sensitivity of $241_{\mathrm{Mn}}$ to varlous reactor parameters as a function of exposure.

D-10. Seneitivity of $242 \mathrm{Ca}$ to various reactor parameter: as a function of exponure. 
D-11. Sensitivity of $244 \mathrm{~cm}$ to various reactor paranetera as a function of exposure.

D-12. Neutron source raten for the five most prominent neutronemitting isotopes and an exposure of $10.860 \mathrm{GNd} / \mathrm{tU}$.

D-13. Neutron wource rates for the five most prominent neutronemitting 1sotopes and an exposure of $19.717 \mathrm{Gd} / \mathrm{tU}$.

D-14. Neutron source rates for the five most prominent neutronenitting isotopes and an exposure of $51.201 \mathrm{GNd} / \mathrm{tU}$.

D-15. Comparison of neutron source rates at discharge as a function of exposure for a detalled power hidtory and a continuou. $200 \mathrm{w} / \mathrm{cm}$ linear power history.

D-16. Comparison of neution source rates at discharge as a function of exposure for continuous power histories of $160 \mathrm{w} / \mathrm{cm}, 200 \mathrm{w} / \mathrm{cm}$, and $240 \mathrm{w} / \mathrm{cm}$.

D-17. Comparison of neutron source rates at a cooling time of 36 monthe as a function of exposure for continuous power hiatories of $160 \mathrm{w} / \mathrm{cm}, 200 \mathrm{w} / \mathrm{cm}$, and $240 \mathrm{w} / \mathrm{cm}$.

D-18. The effect of initial $\mathrm{vO}_{2}$ mass density on the neutron source rate as a function of exposure and cooling time.

D-19. Effect of initial 235 enrichment on the neutron source rate as a function of exposure and cooling time.

D-22. Dependence of correlation betwen $244 \mathrm{Cm}$ and total plutonium on initial $235 \mathrm{v}$ enrichment, initial $\mathrm{UO}_{2}$ mass density, power level, and irradiation history.

D-23. Sensitivity of ${ }^{137} \mathrm{Cs}$ to various reactor parameters as a function of exposure.

D-24. Sensitivity of ${ }^{134} \mathrm{Cs}$ to various reactor parameters as a function of exposure.

D-25. Sensitivity of ${ }^{154}$ Fu to various reactor parameters as a function of exposure.

D-26. Sengitivity of ${ }^{134} \mathrm{Ce} /{ }^{137} \mathrm{Cs}$ to various reactor parameters as a function of exposure.

D-27. Seneitivity of $154_{\mathrm{Eu}} / 137 \mathrm{Cs}$ to various reactor parameters as a function of exposure.

D-28. Dependence of correlation between $134 \mathrm{Cs} / 137 \mathrm{Cs}$ ratio and $2{ }^{9} \mathrm{Pu}$ on initial $235_{\mathrm{J}}$ enrichuent, initial $\mathrm{UO}_{2}$ mass density, power level, and irradiation history.

D-29. Dependence of correlation between ${ }^{154} \mathrm{Ew} / 137_{\mathrm{C}}$ ratio and ${ }^{239} \mathrm{Pu}$ on initial $235 \mathrm{U}$ enrichment, inftial $\mathrm{vO}_{2}$ masa density, power level, and irradiation history.

D-30. Depondence of correlation between ${ }^{134} \mathrm{Cs} / 137 \mathrm{C}$ ratio and the concentration of total finsile material on initial $235 \mathrm{U}$ enrichment, initial $\mathrm{UO}_{2}$ mase density, power level, and irradiation history. 
D-31. Dependence of correlation between ${ }^{154} \mathrm{Eu} / 137 \mathrm{Cs}$ ratio and the concentration of total flosile material on initial $235 \mathrm{U}$ onrichmant, Inftial $\mathrm{UO}_{2}$ mass density, power level, and irradiation hintory.

E-1. Heanured neutron-eminsion rates vs declared burnup for 36 apent PWR assemblies at the $\mathrm{Z}$ ion Generating Station.

E-2. Calculation of weight per cent of $235 \mathrm{U},{ }^{239} \mathrm{Pu}$, and 241pu as a function of burnup.

E-3. Geometric configuration of the active neutron interrogation source, the FWR assembly, and the detector for counting prompt and delayed neutrons.

E-4, Active neutron irradiation and counting cycle for a pulsed-neutron generator using both prompt- and delayed-neutron counting.

E-5. Active neutron irradiation and counting cycle for a modulated 252 Cf neutron source using both promptand delayed-neutron counting.

F-1. Hot cell exterior view.

F-2. Hot cell interior view.

F-3. Fission chamber response to a ${ }^{252} \mathrm{Cf}$ source in water.

F-4. Thermal and epithermal neutron flux at various distances in water from a 252 cf source.

F-5. Fission chamber response ratio (cadmium-covered/bare) for a $252 \mathrm{cf}$ source in a water environment.

F-6. 15 by 15 PWR asuembly available for experiments.

F-7. Rectangular and cylindrical fuel assembly measurement tanks. A 15 by 15 PWR fuel assembly is being lowered into the cylindrical tank.

F-8. Approach-to-critical data for the rectangular tank.

F-9. Sensitivity of active neutron measurements to fuel rod substitution.

F-10. Positioning jig containing a polyethylene-encased fission chamber and a ${ }^{252} \mathrm{Cf}$ holding rod located on top of a $15 \times 15$ PWR-type fuel assembly. 


\begin{tabular}{|c|c|c|c|c|c|}
\hline \multirow{2}{*}{$\begin{array}{c}\begin{array}{c}\text { Reactor } \\
\text { and } \\
\text { Power }\end{array} \\
\end{array}$} & \multirow{2}{*}{$\begin{array}{l}\text { Type } \\
\text { and } \\
\text { Core }\end{array}$} & \multicolumn{2}{|c|}{$\begin{array}{c}\text { Bumup } \\
(\text { mwd/tu })^{a}\end{array}$} & \multirow[b]{2}{*}{ Reprocessor } & \multirow{2}{*}{$\begin{array}{l}\text { No. of } \\
\text { Batches } \\
\text { Processed }\end{array}$} \\
\hline & & Mean & Range & & \\
\hline $\begin{array}{l}\text { JPDR } \\
12.5 \text { MWe }\end{array}$ & $\begin{array}{c}\text { BWR } \\
1\end{array}$ & 3816 & $\begin{array}{ll}1 & 362 \\
5 & 449\end{array}$ & PNCb - Toka1 & 12 \\
\hline $\begin{array}{l}\text { Dresden-1 } \\
210 \text { Mwe }\end{array}$ & $\begin{array}{c}\text { BWR } \\
4\end{array}$ & 10855 & $\begin{array}{r}8500 \\
13400\end{array}$ & $\begin{array}{l}\text { Nuclear Fuel Services } \\
\text { Weat Valley }\end{array}$ & 18 \\
\hline $\begin{array}{l}\text { KRB } \\
250 \mathrm{MWe}\end{array}$ & $\begin{array}{c}\text { BWR } \\
1\end{array}$ & 13957 & $\begin{array}{r}8700 \\
15300\end{array}$ & Eurochemic - Mol & 21 \\
\hline $\begin{array}{l}\text { Trino } \\
257 \text { we }\end{array}$ & $\begin{array}{c}\text { PWR } \\
1\end{array}$ & 12306 & $\begin{array}{r}9900 \\
13400\end{array}$ & Eurochemic - MOI & 16 \\
\hline $\begin{array}{l}\text { Sena } \\
325 \text { mie }\end{array}$ & $\begin{array}{c}\text { PWR } \\
2\end{array}$ & 19877 & $\begin{array}{ll}18 & 637 \\
20 & 612\end{array}$ & Eurochemic - Mol & 12 \\
\hline $\begin{array}{l}\text { Trino } \\
257 \text { MWe }\end{array}$ & $\begin{array}{c}\text { PWR } \\
2\end{array}$ & 20864 & $\begin{array}{ll}14 & 800 \\
22 & 200\end{array}$ & Eurochemic - Mol & 14 \\
\hline $\begin{array}{l}\text { Yankee-Rowe } \\
185 \text { MWe }\end{array}$ & $\begin{array}{c}\text { PWR } \\
\mathbf{8}\end{array}$ & 23654 & $\begin{array}{ll}21 & 300 \\
26 & 700\end{array}$ & $\begin{array}{l}\text { Nuclear Fuel Services } \\
\text { West Valley }\end{array}$ & 11 \\
\hline
\end{tabular}

$\left({ }^{239} \mathrm{Pu},{ }^{241} \mathrm{Pu}\right.$, and $\left.{ }^{235} \mathrm{U}\right)$. The relative difference is defined as:

Relative Difference $(8)=($ Predicted - Measured $) 100$. Because predicted values of plutonium isotopic abundances were not available for Sena core 2, comparisons of fissile plutonium and total fissile content could not be made for that reactor.

Values of the mean, standard deviation, and range for each parameter and each reactor core are presented in Table A-II. Mean burnup, burnup range, and the number of reprocessing batches also are liuted in Table $A-T I$. The resilts were also pooled by reactor type and for all reactors. The pooled data are presented in Tables $A-I I I-A$ and $B$. Pecause of the variability exhibited hy the JPDR data, set of pooled results eliminating the JPDR values is also included. As expected, elimination of the JPDR data decreases the relative standard deviations. The lack of predicted plutonium isotopic abundances for Sena core 2 decreases the number of data points used in the pooled comparisons of total fissile and fissile plutonium content.

The pooled data were tested for the presence of relative bias using student's $t$ test. Comparisons of the calculated $t$ values with the critical values for $\alpha=0.01$ and a two-talled test support the following conclusions.

- There is no significant difference between the predicted and measured total uranium content.

- Thère is a significant positive bias between the predicted and measured total plutonium content.

- There is a significant negative bias between the predicted and measured $235 \mathrm{~J}$ content.

- There is a significant positive bias between the predicted and measured finsile plutonium content for the pooled PWR and 
TALCE A-If

EPENT-TURL COMPOSITION

CONPARIEON OF PMEDICTED AHD MEASUAED VALUES

\begin{tabular}{|c|c|c|c|c|c|c|c|c|c|c|c|c|c|c|c|}
\hline \multirow{3}{*}{$\begin{array}{c}\text { Reactor } \\
\text { and } \\
\text { Power }\end{array}$} & \multirow{3}{*}{$\begin{array}{l}\text { Type } \\
\text { and } \\
\text { Core }\end{array}$} & \multirow{2}{*}{\multicolumn{3}{|c|}{ Durnup a }} & \multirow{3}{*}{$\begin{array}{l}\text { Ho. of } \\
\text { Watchos } \\
\text { procisesed }\end{array}$} & \multicolumn{10}{|c|}{ Selative Difterence (iv) $)^{\mathrm{b}, \mathrm{o}}$} \\
\hline & & & & & & \multicolumn{2}{|c|}{$u$} & \multicolumn{2}{|c|}{ 2u } & \multicolumn{2}{|c|}{$\mathrm{u}^{235}$} & \multirow{2}{*}{\multicolumn{2}{|c|}{$235 \mathrm{Pu}+251 \mathrm{Pu}$}} & \multirow{2}{*}{$\begin{array}{l}\text { Total } \\
\text { Eoton }\end{array}$} & \multirow{2}{*}{$\frac{\text { Finalle }}{\text { Runge }}$} \\
\hline & & & en & trine & & Mañ & hingen & Man & Ronge & Men & Benge & & Rengit & & \\
\hline $\begin{array}{l}\text { JPDR } \\
12,5 \text { nive }\end{array}$ & $\frac{1}{1}$ & 3 & 16 & $\begin{array}{l}1362 \\
3449\end{array}$ & 12 & $\begin{array}{r}1.81 \\
114.23\end{array}$ & $\begin{array}{r}-25.45 \\
35.15\end{array}$ & $\begin{array}{r}21.26 \\
\pm 22.34\end{array}$ & $\begin{array}{r}-24.42 \\
59.98\end{array}$ & $\begin{array}{r}0.734 \\
\pm 13.93\end{array}$ & $\begin{array}{r}-25.49 \\
33.26\end{array}$ & $\begin{array}{r}10.49 \\
222.60\end{array}$ & $\begin{array}{r}-24.13 \\
59.51\end{array}$ & $\begin{array}{r}1.11 \\
\pm 14.03\end{array}$ & $\begin{array}{r}-25.30 \\
34.30\end{array}$ \\
\hline $\begin{array}{l}\text { Dreaden-1 } \\
210 \text { inte }\end{array}$ & ank & 10 & ess & $\begin{array}{r}5300 \\
13400\end{array}$ & 18 & $\begin{array}{l}-0.058 \\
+2.02\end{array}$ & $\begin{array}{r}-5.29 \\
2.12\end{array}$ & $\begin{array}{r}0.19 \\
24.24\end{array}$ & $\begin{array}{l}-6.05 \\
10.58\end{array}$ & $\begin{array}{l}-7.14 \\
\$ 3.19\end{array}$ & $\begin{array}{r}-11.00 \\
-0.84\end{array}$ & $\begin{array}{l}-5.25 \\
\pm 5.07\end{array}$ & $\begin{array}{r}-11.68 \\
7.44\end{array}$ & $\begin{array}{l}-6.53 \\
\pm 3.57\end{array}$ & $\begin{array}{r}-10.24 \\
1.55\end{array}$ \\
\hline$\frac{k R e}{250}$ & awk & 13 & 957 & $\begin{array}{r}8700 \\
15300\end{array}$ & 21 & $\begin{array}{r}2.46 \\
\pm 4.44\end{array}$ & $\begin{array}{l}-3.06 \\
15.64\end{array}$ & $\begin{array}{r}5.67 \\
25.69\end{array}$ & $\begin{array}{l}-2.41 \\
18.31\end{array}$ & $\begin{array}{l}-0.037 \\
\pm 4.52\end{array}$ & $\begin{array}{l}-5.68 \\
10.07\end{array}$ & $\begin{array}{r}3.26 \\
\$ 5.64\end{array}$ & $\begin{array}{l}-4.14 \\
16.79\end{array}$ & $\begin{array}{r}0.81 \\
\pm 4.39\end{array}$ & $\begin{array}{r}-4.63 \\
8.16\end{array}$ \\
\hline $\begin{array}{l}\text { Trino } \\
257 \text { ine }\end{array}$ & Pwh & 12 & 306 & $\begin{array}{r}9900 \\
13400\end{array}$ & 16 & $\begin{array}{r}0.57 \\
\pm 2.14\end{array}$ & $\begin{array}{r}-0.67 \\
\text { A. } 30\end{array}$ & $\begin{array}{r}3.74 \\
\pm 3.14\end{array}$ & $\begin{array}{r}-3.33 \\
9.43\end{array}$ & $\begin{array}{l}-2.10 \\
22.25\end{array}$ & $\begin{array}{r}-3.31 \\
5.79\end{array}$ & $\begin{array}{r}4.39 \\
22.97\end{array}$ & $\begin{array}{l}-2.46 \\
10.17\end{array}$ & $\begin{aligned} & 0.063 \\
& \pm 2.10\end{aligned}$ & $\begin{array}{r}-1.72 \\
6.79\end{array}$ \\
\hline $\begin{array}{l}\text { Sena } \\
325 \text { miwe }\end{array}$ & PWR & 29 & B77 & $\begin{array}{ll}18 & 637 \\
20 & 612\end{array}$ & 12 & $\begin{array}{l}-1.16 \\
\pm 1.21\end{array}$ & $\begin{array}{r}-2.86 \\
0.52\end{array}$ & $\begin{array}{l}-1.62 \\
\pm 3.82\end{array}$ & $\begin{array}{r}-9.09 \\
6.18\end{array}$ & $\begin{array}{l}\mathbf{- 6 . 0 2} \\
\pm 3.76\end{array}$ & $\begin{array}{r}-16.84 \\
-2.93\end{array}$ & - & - & - & - \\
\hline $\begin{array}{l}\text { Txino } \\
254 \text { me }\end{array}$ & $\underset{2}{P W R}$ & 20 & 864 & $\begin{array}{l}14800 \\
22200\end{array}$ & 14 & $\begin{array}{r}0,23 \\
\leq 1.23\end{array}$ & $\begin{array}{r}-1.38 \\
2.97\end{array}$ & $\begin{array}{r}7.21 \\
\pm 2.89\end{array}$ & $\begin{array}{l}-0.56 \\
10.99\end{array}$ & $\begin{array}{l}-6.17 \\
\pm 3.11\end{array}$ & $\begin{array}{r}-11.36 \\
-1.11\end{array}$ & $\begin{array}{r}6.68 \\
\pm 2.89\end{array}$ & $\begin{array}{l}-0.93 \\
10.62\end{array}$ & $\begin{array}{l}-2.61 \\
\pm 2.11\end{array}$ & $\begin{array}{r}-6.16 \\
1.31\end{array}$ \\
\hline $\begin{array}{l}\text { Yankes-Rowe } \\
\text { i85 mie }\end{array}$ & $\begin{array}{c}\text { PWR } \\
\text { B }\end{array}$ & 23 & 654 & $\begin{array}{ll}21 & 300 \\
26 & 700\end{array}$ & 11 & $\begin{array}{r}0.54 \\
\pm 1.74\end{array}$ & $\begin{array}{r}-3.44 \\
2.91\end{array}$ & $\begin{array}{r}4.22 \\
\pm 2.74\end{array}$ & $\begin{array}{r}-0.60 \\
9.58\end{array}$ & $\begin{array}{l}-1.17 \\
\pm 2.85\end{array}$ & $\begin{array}{r}-5.97 \\
3.03\end{array}$ & $\begin{array}{r}6.27 \\
+2.55\end{array}$ & $\begin{array}{r}1.15 \\
10.69\end{array}$ & $\begin{array}{r}0.51 \\
\pm 2.24\end{array}$ & $\begin{array}{r}-2.92 \\
4.10\end{array}$ \\
\hline
\end{tabular}

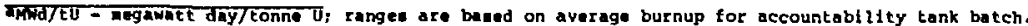

[ $\frac{\text { Predicted - Meanured }}{\text { Hentured }} 100$.

CThe : veluee are relative standerd deviatlone in per cent.

for the pooled PWR and BWR data (with and without JPDR). Variabilfty in the JPDR data masks possible biases hetween the predicted and measured data for the BWRs. A negative bias 1s, in fact, obtained between the predicted and measured fissile plutonfum content for the BWRs if the JPDR data are eliminated.

- The pooled data for PWRg and BWRg, excluding the JPDR data, show a significant negative bias for the total figsile content.

\section{DISCUSSION}

It is reasonable that for all except the JPDR data the significant differences observed between reactor optrator's and reprocessor's values are caused primarily by inaccurate reactor predictions. Th1s is reasonable because the analytical chenigtry and mass pectrometric methods should be more accurate and precise than is indicated by the observed differences, and, for all but the JPDR data, there are independent confimatory measurements that agree well with the reprocessor's data.

Under the hypothesis that most of the observed aifferences are caused by inaccurate burnup calculations, we restate the conclusions of this study as follows.

- Total uranium content is predicted with an insignificant bias of 1 or less and $a$ variability $(2 \sigma)$ of $2-4 t$.
- Total plutonium content is predicted with a positive blas of $3-58$ and a variability (10) of $4-68$.

- Fissile uranium $\left({ }^{235} \mathrm{U}\right)$ content is preaicted with a negative bias of $3-48$ and a variability $(1 \dot{\sigma})$ of $4-68$.

- Fissile plutoniun $\left({ }^{239} \mathrm{Pu}+{ }^{241} \mathrm{Pu}\right)$ is predicted with a bias of -1 to $+6 \%$ and a variability (10) of 3-7s.

- Total fissile content is predicted with a negative bias of $1-3 \%$ and a vartability (10) of 3-6s.

In most cases the larger values of the ranges quoted for accuracy and precision are associated with BWRa and the lower values with PWRs. Also, there are probable outliers in the data; for example, considering only total uranium and neglecting the JPDR data, a range of LIO $^{18}$ observed in the PWR data and 220 in the BWR data. Differences might be even larger for individual fuel assemblies because each reprocessing batch consists of two or more assemblies so that there is some averaging of the assmmbly data.

The data base used for this study does not include any data for large, modern nuclear power plants becaues fuel from such plants currently is not being reprocessed. Modern fuels are being designed for highex burnups. The conclusions of this study should be re-examined when burnup data for modern fuels become avallable. 
SPENT-FUEL COHPOSITION

POOLED CONPARISONS OF PKEDICTED AND MEASURED VALUES

A: uranium, Plutonjum

\begin{tabular}{|c|c|c|c|c|c|c|c|c|c|c|c|}
\hline \multirow[b]{3}{*}{ Reactor Type } & \multirow{3}{*}{$\begin{array}{l}\text { Number } \\
\text { of } \\
\text { Betches }\end{array}$} & \multirow{2}{*}{\multicolumn{4}{|c|}{$\begin{array}{l}\text { Burnup } \\
\text { MWd/tu }\end{array}$}} & \multicolumn{6}{|c|}{ Relative Difference $(8)^{b}$} \\
\hline & & & & & & \multicolumn{2}{|l|}{$\mathbf{u}$} & \multicolumn{2}{|c|}{$\mathrm{Pu}$} & \multicolumn{2}{|c|}{2350} \\
\hline & & & sen & EN & nge & Hean & Range & Mean & Range & Mean & Range \\
\hline $\begin{array}{l}\text { BWRs (JPDR, } \\
\text { Dreaden and } \\
\text { KRB) }\end{array}$ & 51 & 10 & 476 & 15 & $\begin{array}{l}362 \\
300\end{array}$ & $\begin{array}{r}1.42 \\
\pm 7.42\end{array}$ & $\begin{array}{r}-25.45 \\
35.15\end{array}$ & $\begin{array}{r}4.90 \\
\pm 12.16\end{array}$ & $\begin{array}{r}-21.42 \\
59.98\end{array}$ & $\begin{array}{l}-2.36 \\
\pm 8.19\end{array}$ & $\begin{array}{r}-25.49 \\
33.28\end{array}$ \\
\hline $\begin{array}{l}\text { BWRa (Dresden } \\
\text { and } K \mathrm{~KB} \text { ) }\end{array}$ & 39 & 12 & 525 & $\begin{array}{r}8 \\
15\end{array}$ & $\begin{array}{l}600 \\
300\end{array}$ & $\begin{array}{r}1.30 \\
\pm 3.72\end{array}$ & $\begin{array}{l}-5.19 \\
15.64\end{array}$ & $\begin{array}{r}2.97 \\
+5.82\end{array}$ & $\begin{array}{l}-6.05 \\
18.31\end{array}$ & $\begin{array}{l}-3.32 \\
\pm 5.31\end{array}$ & $\begin{array}{r}-11.00 \\
10.07\end{array}$ \\
\hline PWRa & 53 & 18 & 636 & $\begin{array}{r}9 \\
26\end{array}$ & $\begin{array}{l}900 \\
700\end{array}$ & $\begin{array}{r}0.081 \\
\pm 1.75\end{array}$ & $\begin{array}{r}-3.44 \\
8.30\end{array}$ & $\begin{array}{r}3.52 \\
+4.37\end{array}$ & $\begin{array}{r}-9.09 \\
10.99\end{array}$ & $\begin{array}{r}-3.57 \\
\pm 3.84\end{array}$ & $\begin{array}{r}-16.81 \\
5.79\end{array}$ \\
\hline BWRS and PWRs & 104 & 14 & 634 & $\begin{array}{r}1 \\
26\end{array}$ & $\begin{array}{l}362 \\
700\end{array}$ & $\begin{array}{r}0.74 \\
+5.36\end{array}$ & $\begin{array}{r}-25.45 \\
35.15\end{array}$ & $\begin{array}{r}4.19 \\
+9.05\end{array}$ & $\begin{array}{r}-21.42 \\
59.98\end{array}$ & $\begin{array}{l}-2.98 \\
\pm 6.36\end{array}$ & $\begin{array}{r}-25.49 \\
33.28\end{array}$ \\
\hline $\begin{array}{l}\text { HWR: and PWRs } \\
\text { (excluding } \\
\text { JPDR) }\end{array}$ & 92 & 16 & 045 & $\begin{array}{r}8 \\
26\end{array}$ & $\begin{array}{l}500 \\
700\end{array}$ & $\begin{array}{r}0.60 \\
\pm 2.81\end{array}$ & $\begin{array}{r}-5.19 \\
15.64\end{array}$ & $\begin{array}{r}3.29 \\
45.01\end{array}$ & $\begin{array}{r}-9.09 \\
18.31\end{array}$ & $\begin{array}{l}-3.46 \\
\pm 4.50\end{array}$ & $\begin{array}{r}-16.04 \\
10.07\end{array}$ \\
\hline
\end{tabular}

B: Fissile Pu and Total Fissile

\begin{tabular}{|c|c|c|c|c|c|c|c|c|c|}
\hline \multirow[b]{3}{*}{ Redetor Type } & \multirow{3}{*}{$\begin{array}{c}\text { Number } \\
\text { of } \\
\text { Batches }\end{array}$} & \multirow{2}{*}{\multicolumn{4}{|c|}{$\begin{array}{l}\text { Burnup } \\
\text { Mind/tu }\end{array}$}} & \multicolumn{4}{|c|}{ Relative Difiecence $(1)^{b}$} \\
\hline & & & & & & \multirow{2}{*}{$\frac{239 \mathrm{Pu}}{\text { Mean }}$} & \multirow{2}{*}{$\frac{241_{\mathrm{Pu}}}{\text { Range }}$} & \multirow{2}{*}{$\begin{array}{l}\text { Total } \\
\text { Mean } \\
\end{array}$} & \multirow{2}{*}{ Fissile } \\
\hline & & & ean & Ran & nge & & & & \\
\hline $\begin{array}{l}\text { BWRs (JPDR, } \\
\text { Uresden and } \\
\text { KBR) }\end{array}$ & 51 & 10 & 476 & & $\begin{array}{l}362 \\
530\end{array}$ & $\begin{array}{r}1.96 \\
\pm \$ 3.07\end{array}$ & $\begin{array}{r}-21.43 \\
59.51\end{array}$ & $\begin{array}{l}-1.71 \\
\pm 8.26\end{array}$ & $\begin{array}{r}-25 \cdot 30 \\
34.30\end{array}$ \\
\hline $\begin{array}{l}\text { BWRs (Dresden } \\
\text { and KRB) }\end{array}$ & 39 & 12 & 525 & $\begin{array}{r}8 \\
15\end{array}$ & $\begin{array}{l}500 \\
300\end{array}$ & $\begin{array}{l}-0.67 \\
\pm 6.84\end{array}$ & $\begin{array}{r}-11.68 \\
16.79\end{array}$ & $\begin{array}{l}-2.58 \\
\pm 5.44\end{array}$ & $\begin{array}{r}-10.24 \\
8.16\end{array}$ \\
\hline $\begin{array}{l}\text { PWRs (exclud- } \\
\text { ing Sena) }\end{array}$ & 41 & 18 & 273 & $\begin{array}{r}9 \\
26\end{array}$ & $\begin{array}{l}900 \\
700\end{array}$ & $\begin{array}{r}5.68 \\
\pm 2.96\end{array}$ & $\begin{array}{l}-2.46 \\
10.69\end{array}$ & $\begin{array}{l}-0.73 \\
\pm 2.50\end{array}$ & $\begin{array}{r}-6.16 \\
6.79\end{array}$ \\
\hline $\begin{array}{l}\text { PWRs and BWRs } \\
\text { (excluding Sena) }\end{array}$ & 92 & 13 & 951 & $\begin{array}{r}1 \\
26\end{array}$ & $\begin{array}{l}362 \\
700\end{array}$ & $\begin{array}{r}3.61 \\
\pm 10.06\end{array}$ & $\begin{array}{r}-24.13 \\
59.51\end{array}$ & $\begin{array}{l}-1.27 \\
\pm 6.36\end{array}$ & $\begin{array}{r}-25,30 \\
34.30\end{array}$ \\
\hline $\begin{array}{l}\text { PWRs and BWRs } \\
\text { (excluding Sena } \\
\text { and JPDR) }\end{array}$ & 80 & 15 & 471 & $\begin{array}{r}8 \\
26\end{array}$ & $\begin{array}{l}500 \\
700\end{array}$ & $\begin{array}{r}2.58 \\
\pm 6.09\end{array}$ & $\begin{array}{r}-11.68 \\
16.79\end{array}$ & $\begin{array}{l}-1.63 \\
\pm 4.27\end{array}$ & $\begin{array}{r}-10.24 \\
6.79\end{array}$ \\
\hline
\end{tabular}

amw/tU = megawatt day/tonne $U_{\text {; }}$ ranges are based on average burnup for accountability batches.

b( $\frac{\text { Predicted - Measured }}{\text { Predicted }} 100$.

Based on the results of this gtudy, NDA measurements on spent fuel that are accurate and precise to 5-10s (10) or better should be useful for guantitative verification of "typical" apent fuel, that is, fuel with normal irradiation history. Such measurements should also be ueeful for characterizing "atypical" fuel, that is, fuel with inhomogeneous burnup or unusual irradiation history.

\section{REEERENCES}

1. D. D. Cobb, Id., "Spent-Fuel Storage Facility Project, June-September 30, 1979," Lo: Alamos Scientific Laboratory report LA-8237-PR (June 1980).
2. C. C. Thomas, Jr*, D. D. Cobb, and C. A. Ostenak, "Spent-Fuel Composition: A Comparison of Predicted and Measured Data," Ios Mlamo: National Laboratory report LA-8764-MS (March 1981).

3. C. L. Timmerman, "Isotopic Safeguarde Data Bank (ISTLIB) and Control Program (MISTY)." Battelle Pacific Northwest Luboratory report ISPO-34 (PNL-2726) (Septeriber 1978).

4. H. Unezawa, "Irotope Safeguards Techniques at the Tokal Reprocessing Plant Tastex; Task-x," Japan Atomic Energy Research Institute report (April 1979).

5. C. Beeta, H. Balriot, P. Bemelmane, F. Franssen, "Application of the CWy/SCX Data Bank to the Reprocessed Fuel," in Irotoplc Correlution and 1te Application to the Nuclear ruel crcle. Proc. Symp., stresa, Italy, May 9-11, 1978 (European Safeguard. Deearch and Developent Association), ICT-25. 
APPANDIX B

GE-WORRIS EXPERIMENTA, PROGRAM

J. R. Ph1llips, J. K. Halk1g, and S. F. Klosterbuer Safoguarda Assay Group $Q-1$

:. INTRODUCTION

The effectiveness and operational acceptability of new measurenent systems must be demonstrated in actual nuclear facilities. To develop and demonstrate the capabilities of nondestructive measurement syatems for spent fuel, prototype systens are being teated at the GE-Morris operation Spent-Fuel storage Facility. The initial measurement system was installed at GE-Worrig, and the first geries of experiments was carried out during the fall of 1980, The results of this first series of measurements are described here.

The measurement system currently installed at GE-Korris is being upgraded for a second series of experiments scheduled for the summer of 1981. Concurrently, based on the results of our laboratory and field experience, we are deslgning a second prototype system that will incorporate spectral gamma-ray and antive neutron measurements. This second system is tentatively scheduled for installation at GE-Morris in mid-1982, following checkout and testing at Los Alamos.

II. EXPERTMENTAL APPARATUS

h spent-fuel measurement systen was irstalled at the GE-Morris Operation Spent-Fuel storage Facility to evaluate the applicability of passive gamma-ray and neutron measurement techniques to the" verification of irradiated fuel assemblies at a spent-fuel storage facility. A mematic of the system initially installed during october 1980 is show in Fig. B-1. The positioning mechanism ( $V$-shaped device) automatically centers the fuel assembly as the crane moves in to the wall. This geometry was selected because it maintains the same source-to-detector distance for both pressurizedwater-reactor (PWR) and bolling-water-reactor (BWR) fuel assemblies. Figure B-2 shows a representation of a BWR fuel assembly located in the positioning mechanism. The detector pipe is located at the corner of the fuel assembly to ensure a symmetric measurement geometry. The first detector package (Fig. B-3) consisted of three detectors: (1) an ion chamber to measure gross gamma dose, (2) a ${ }^{235} \mathrm{U}$ fission chamber ( $\left.120 \mathrm{mg}{ }^{235} \mathrm{U}\right)$ to measure the neutron emission rate, and (3) a $B e(\gamma, n)$ detector to record the high-energy (>1.66-MeV) gamma signature.

\section{LOCATING ASSEMBLY WITH} DETECTOR TUBE

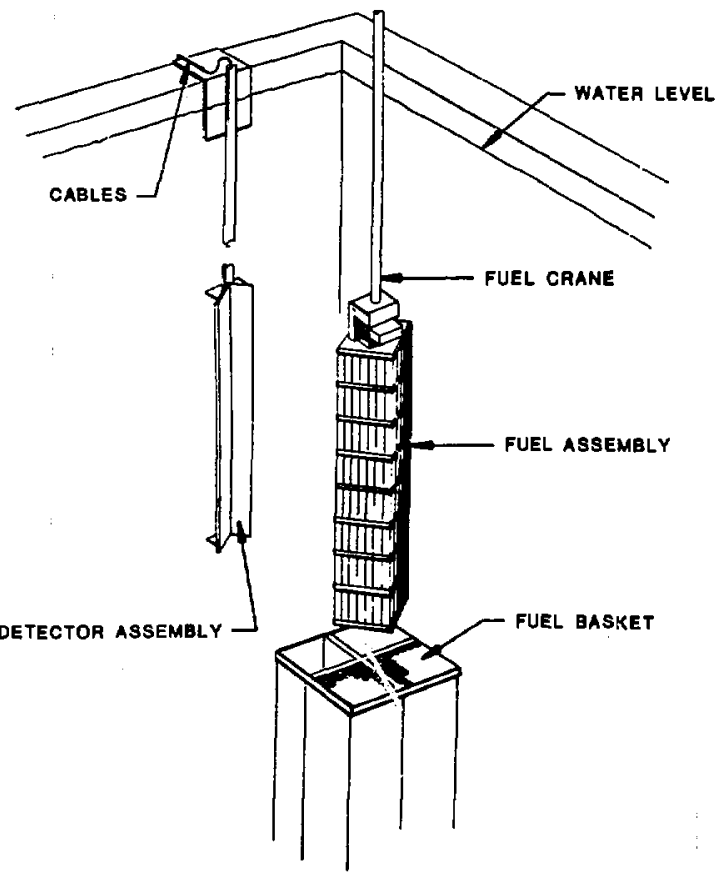

Fig. B-1.

Positioning mechanism for prototype verification and assay system. 
LOCATING ASSEMBLY WITH DETECTOR TUBE

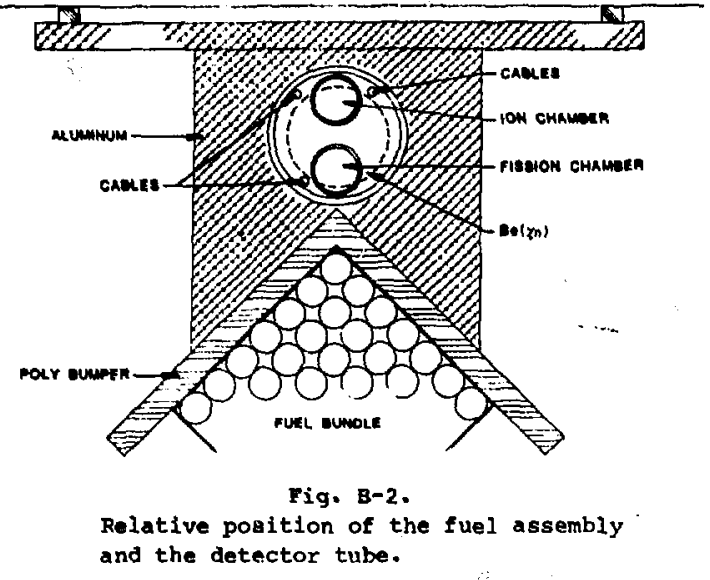

The Be $(Y, n)$ detector is shown in Fig. B-4. High-energy gamma rays $(>1,66 \mathrm{MeV})$ interact with beryllium, producing neutrons that are thermalized in the polyethylene and detected using a small $235 \mathrm{u}$ fission chamber $\left(235 \mathrm{mg}{ }^{235} \mathrm{U}\right)$. The principal source of high-energy gamma rays is the 2186-kev gamma ray from the decay of ${ }^{244} \mathrm{Pr}$. The halflife of ${ }^{144}$ Pr is only $17.28 \mathrm{~min}$; however, it is in secular equilibrium with its parent ${ }^{144} \mathrm{Ce}$ $\left(t_{1 / 2}=284.5\right.$ days $)$. For fuel assemblies with Jong cooling times ( $27 \mathrm{yr}$ ), this signature probably would not be detectable. For fuel assemblies with short cooling times, this high-energy signature would be difficult to simulate and therefore woula he a good indication that there had been no tampering with the fue].

\section{IIT. EXPFRIMENTAI, RESULTS}

The spent-fuel measurement system instalied in the unloading pool at GE-Morris is shown in Fig. B-5. Spent-fuel assemblies from four reactors were examined using fission chambers to measure neutron emission rates and ion chambers to measure gamma doses. There were four objectives of these initial measurements.

(1) Reproducibility: Hor precise could replicate messurements be mare using the V-shaped positioning fixture; Also, could the errors covered by positioning and counting statistics be separated? which of these two errox sources is dominant?

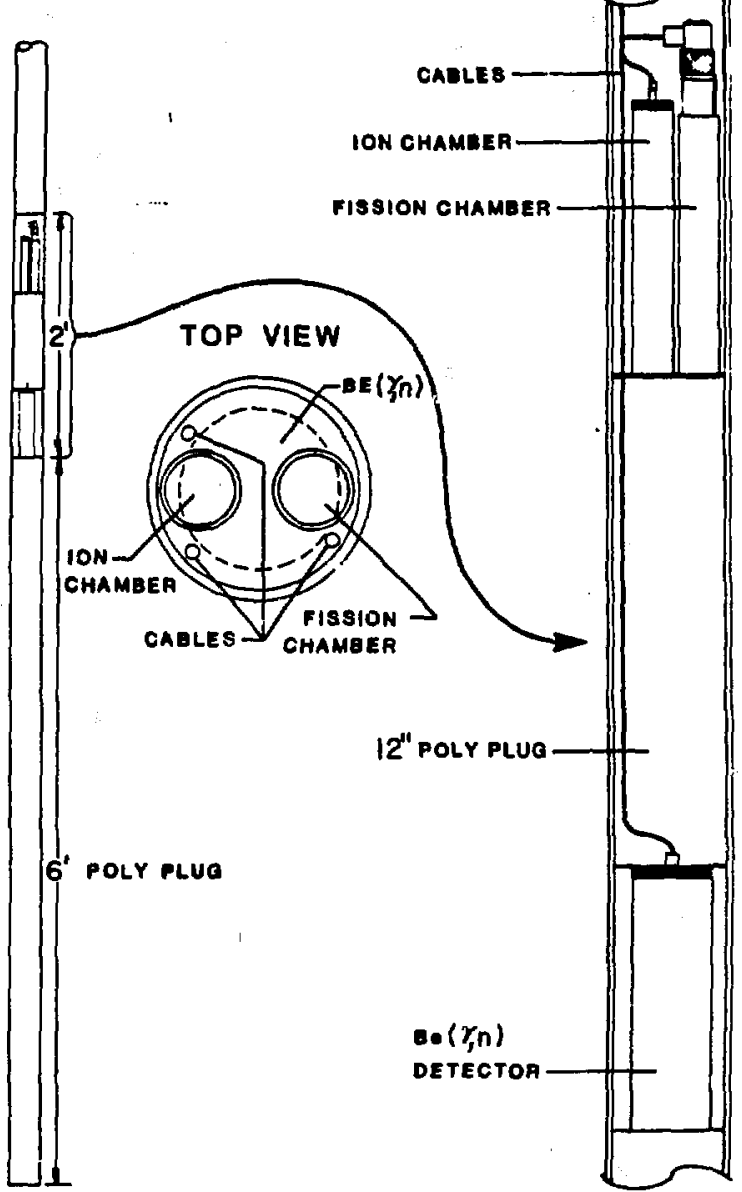

Fig. B-3.

Detector package used in the GE-Morris field exercise.

(2) Angular Effects: Are the neutron and gamma-ray measurements at all four corners of the spent-fuel assembly consistent?

(3) Evaluation of Empirical Correlations: Does the empirical relationship between neutron emission rate and declared exposure apply to fuel assemblies from different reactors? Can the neutron emission rate be corrected for decay of the ${ }^{244} \mathrm{~cm}$ isotope?

(4) Fuel-Assembly Geometry: What is the effect on measurements of variations in fuel geometry--PWR fuel assemblies with 14 by 24 and 15 by 15 arrays, and BWR fuel assemblies with 7 by 7 arrays?

To address these questions, we measured a total of 17 spent-fuel assemblies, 16 PWR asemblies and i BWR assembly, from four power reactors. 


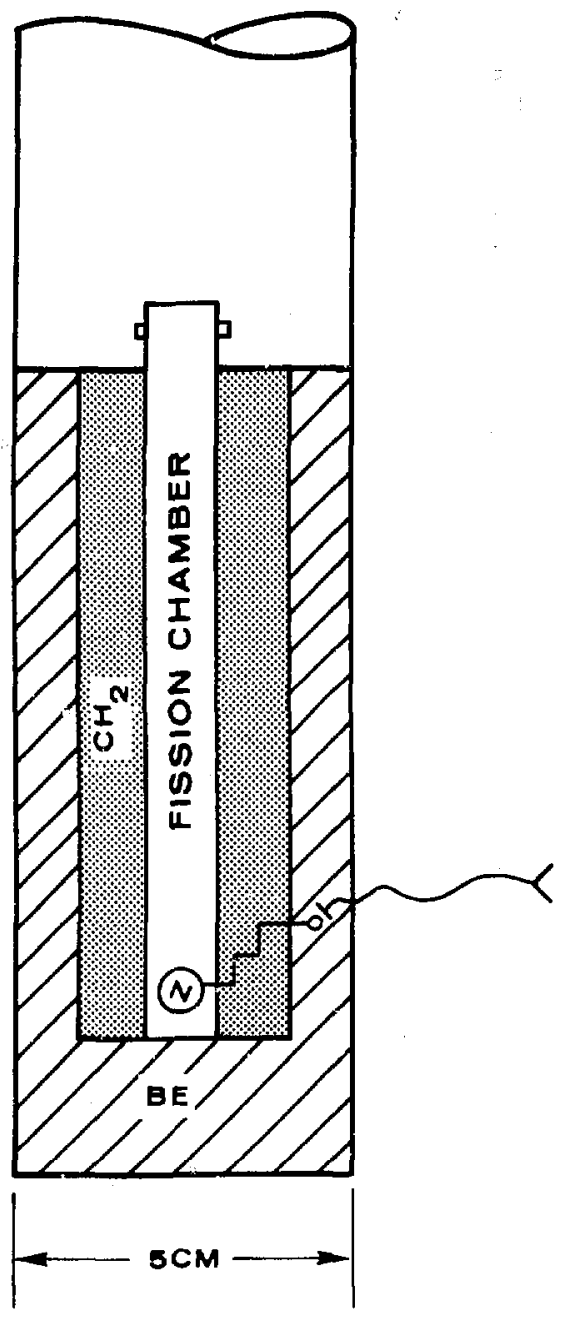

Fig. B-4.

$\operatorname{Be}(\gamma, n)$ detector that is sensitive to only high-energy $(>1.66 \mathrm{MeV})$ gamma rays.

Table B-I summarizes the parameters of the fuel assemblies. The specific fuel assemblies that were measured are described in Table B-II.

\section{A. Reproductbllity}

The positioning mechanism consisted of a v-shaped holder with two limit switches, one on each side of the $v$, to indicate when the fuel assembly was in position. Two types of positioning procedures were investigated for assembly number B-C032: (1) measurement when both limit switches indicated contact and (2) measurement when the assembly was placed firmiy against the v-ohaped

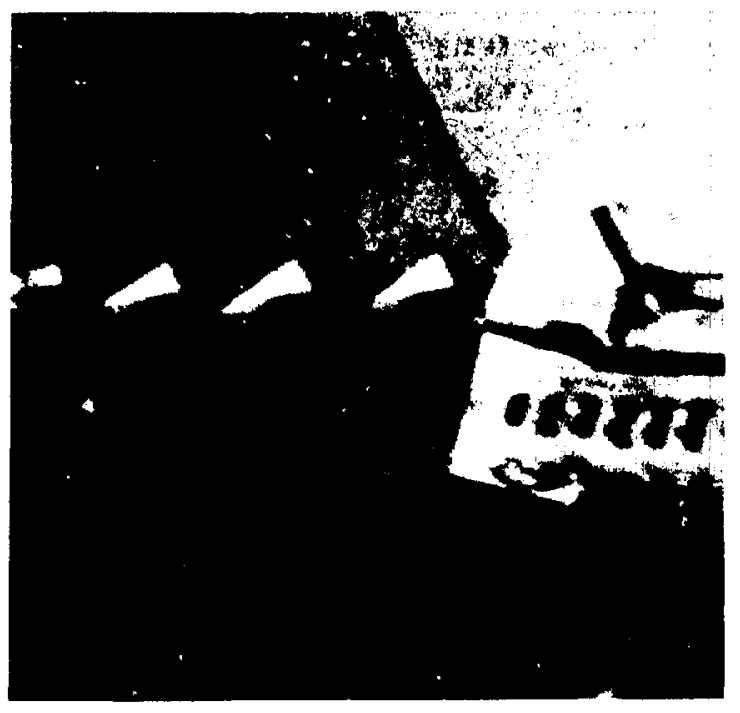

Fig. B-5.

Spent-fuel measurement syatem installed in the GE-Horris unloading pool.

positioning mechanism. Each of the four corners of B-CO32 was measured six times using both procedures (limit switch and fixed). Following each measurenent, the fuel assembly was removed frcm the positioning mechanism and realigned to simulate an independent measurement. Kesults of these replicate measurements (Table B-III) indicate that. better reproducibility is obtained when the fuel assembly is placed firmly against the positioning fixture, as compared with using the linit switches alone to indicate correct positioning. In the optimum procedure the limit switches were used to indicate when the fuel assembly was getting close to the correct position, and final positioning was confirmed by visual inspection. This procedure provided measurement reproducibility of 1-28.

Following the reproducibility tests, the beryllium sleeve was removed from the $B e(\gamma, n)$ detector to ensure that photoneutrons produced in the beryllium did not contribute to the observed counts in the fission chamber. The flssion chamber of the $B e(\gamma, n)$ detector was left in the detector assembly, so that two simultaneous neutron measurements could be made for each fuel assembly. additional investigations are being conducted to quantify the effect of the $B e(\gamma, n)$ detector on the 
TABLE D-I

FULL ASSEMBLIES EXAMINLD AT GE-MORHIS FACILITY

\begin{tabular}{|c|c|c|c|c|c|c|c|c|c|c|c|}
\hline $\begin{array}{c}\text { Reactor } \\
\text { Designation }\end{array}$ & $\begin{array}{r}\text { Rated } \\
\text { Rasctor } \\
\end{array}$ & $\begin{array}{l}\text { out put } \\
\text { (YyEe) }\end{array}$ & $\begin{array}{l}\text { Number of } \\
\text { Ansenblies }\end{array}$ & $\begin{array}{c}\text { Fuol } \\
\text { Geoputry }\end{array}$ & $\begin{array}{c}\text { Tued } \\
\text { Dianet ar } \\
\text { (ca) } \\
\end{array}$ & $\begin{array}{l}\text { Active } \\
\text { Length } \\
\text { (cci) }\end{array}$ & $\begin{array}{l}\text { Cladding } \\
\text { Material }\end{array}$ & $\begin{array}{l}\text { Fuel Rods/ } \\
\text { Angenbly }\end{array}$ & $\begin{array}{c}235 u \\
\text { Enrichment } \\
\text { (1) }\end{array}$ & $\begin{array}{l}\text { Declared } \\
\text { Exponure } \\
\text { (GWd/tu) } \\
\end{array}$ & $\begin{array}{c}\text { per Fuel } \\
\text { Anenbly } \\
(\mathrm{kg})\end{array}$ \\
\hline A & $510 \mathrm{WHe}$ & (PNR) & 4 & $15 \times 15$ & 0.97 & 309.4 & $\mathbf{z r}$ & 204 & $3.02-3.67$ & $10.8-26.0$ & 419.7 \\
\hline B & $450 \mathrm{We}$ & (DWR) & 3 & $14 \times 14$ & 0.93 & 366 & $2 x$ & 179 & 1.4 & $23.6-40.7$ & 443,7 \\
\hline c & 715 mie & (BWR) & 1 & $7 \times 7$ & 1.24 & 366 & $2 x$ & 49 & 2,13 & 5.1 & 169.8 \\
\hline D & $430 \mathrm{mw}$ & (PWR) & 9 & {$[4 \times 14$} & 0.97 & 305 & ss & 180 & $3.4-4.0$ & $26.5-32.4$ & 318.5 \\
\hline
\end{tabular}

TABLE B-II

INDIVIDUAL FUEL ASSEMBLIES

\begin{tabular}{|c|c|c|c|}
\hline $\begin{array}{c}\text { Fuel } \\
\text { Assembly }\end{array}$ & $\begin{array}{c}\text { Di scharge } \\
\text { Date } \\
\end{array}$ & $\begin{array}{l}235 \mathrm{U} \text { Enr } i \text { chment } \\
\text { (t) }\end{array}$ & $\begin{array}{c}\text { Declared Exposure } \\
(G W d / t U)\end{array}$ \\
\hline $\begin{array}{l}A-A 019 \\
A-C 049 \\
A-A O 45 \\
A-B 012\end{array}$ & $\begin{array}{l}4 / 17 / 70 \\
4 / 17 / 70 \\
4 / 17 / 70 \\
4 / 16 / 71\end{array}$ & $\begin{array}{l}3.02 \\
3.67 \\
3.02 \\
3.23\end{array}$ & $\begin{array}{l}39.7 \\
10.8 \\
19.5 \\
26.0\end{array}$ \\
\hline $\begin{array}{l}B-\cos 6 \\
B-\cos 2 \\
B-\cos 2\end{array}$ & $\begin{array}{l}3 / 4 / 77 \\
4 / 6 / 74 \\
3 / 4 / 77\end{array}$ & $\begin{array}{l}3.397 \\
3.400 \\
3.397\end{array}$ & $\begin{array}{l}40.7 \\
23.6 \\
32.8\end{array}$ \\
\hline$C-D N 201$ & $4 / 72$ & 2.13 & 5.1 \\
\hline $\begin{array}{l}D-A 051 \\
D-C 004 \\
D-D 001 \\
D-C 001 \\
D-A 036 \\
D-D 020 \\
D-A 009 \\
D-D 046 \\
D-C 020\end{array}$ & $\begin{array}{c}12 / 28 / 72 \\
6 / 21 / 73 \\
3 / 14 / 75 \\
6 / 2 / 73 \\
12 / 28 / 72 \\
3 / 14 / 75 \\
12 / 28 / 72 \\
3 / 14 / 75 \\
6 / 2 / 73\end{array}$ & $\begin{array}{l}3.404 \\
3.865 \\
4.005 \\
3.865 \\
3.404 \\
4.005 \\
3.404 \\
4.005 \\
3.865\end{array}$ & $\begin{array}{l}26.7 \\
26.8 \\
31.4 \\
26.5 \\
26.5 \\
26.9 \\
26.8 \\
32.3 \\
32.4\end{array}$ \\
\hline
\end{tabular}

passive neutron measurements for the specific detector design. The fission chamber in the $B e(Y, n)$ detector contained $58 \mathrm{mg} 9382.35 \mathrm{U}$, whereas the larger fission chamber contained $165 \mathrm{mg}$.

A third technique for positioning the fuel assemblies was evaluated in which the gross gama activity was monitored using the fon chamber as the fuel assembly was moved into the positioning mechanism. This signal would reach a maximum when the fuel assembly was closest to the detector package. As tile fuel-assembly grapple was moved further, the fuel assembly would pivot away from the detector causing the gross gamm signal to drop. This technique was found to compare favorably with the optimum procedure for positioning and eliminated any influence on the measurements arising from different operators.

The next series of measurements was performed to quantify the reproducibility of measurements for various fuel assenbly designs. Two 14 by 14 PirR, one 15 by 15 PWR, and one 7 by 7 BWR fuel assemblies were each neasured a minimum of $1 x$
TAELE B-III

CONEARISON OF MEASUREMENTS USING LIMIT SHITCHES AND FIXED POSITION - FUEL ASSTMLY B-C032

\begin{tabular}{|c|c|c|c|c|c|c|}
\hline \multirow[b]{2}{*}{ Orjentation } & \multicolumn{2}{|c|}{$\frac{\text { Fission Chamber }}{\text { Ifmit }}$} & \multicolumn{2}{|c|}{ Ion Chumber } & \multicolumn{2}{|c|}{ Be $(\gamma, \pi)$ Detector } \\
\hline & $\begin{array}{l}\text { Efmit } \\
\text { switeh } \\
\text { (1) }\end{array}$ & $\begin{array}{c}\text { Fixed } \\
(v)\end{array}$ & $\begin{array}{c}\text { Indt } \\
\text { Switeh } \\
\text { (v) }\end{array}$ & $\begin{array}{l}\text { Fixed } \\
\text { (v) }\end{array}$ & $\begin{array}{l}\text { Limit } \\
\text { Switeh } \\
\text { (N) } \\
\end{array}$ & $\begin{array}{c}\text { Fixed } \\
\text { (1) }\end{array}$ \\
\hline$A$ & 5.5 & 1.0 & 4.0 & 0.9 & 5.5 & 2,4 \\
\hline $\mathbf{B}$ & 4.3 & 0.8 & 2.6 & 0.0 & 4.0 & 1.9 \\
\hline c & 5.0 & 1.7 & 4.0 & 0.8 & 5.3 & 2,4 \\
\hline D & $\underline{5.6}$ & $\underline{2.3}$ & 4.1 & 0.8 & 6.5 & 3,1 \\
\hline Average & $\begin{array}{c}5.1 \\
(0.9)^{a}\end{array}$ & $\begin{array}{c}1.5 \\
(0.9)^{a}\end{array}$ & $\begin{array}{c}3.7 \\
(0.3)^{a}\end{array}$ & $\begin{array}{c}0.6 \\
(0.3)^{a}\end{array}$ & $\begin{array}{c}5.3 \\
(1.5)^{2}\end{array}$ & $\begin{array}{c}2.5 \\
(1.4)^{a}\end{array}$ \\
\hline
\end{tabular}

Expected exrors from counting statietics for neutron measurements. The lon chamber meatures analog current. Errors quoted for the Ion chanbex correspond to ane-unit change in the least eignificant digit.

tines at each corner. The fuel assembly was repositioned for each measurement. For the three PWR fuel assemblies, the variation of neutron measurements was 1.1 and the variation of the ion chamber measurements was 0.68 when the optimum (fixed) positioning procedure was used. Also, during this series of measurements, at least four different fuel-handling operators performed the positioning without adversely affecting the messurements. In Table B-IV the estimated variations (10) caused by counting statistics are glven in parentheses. By comparing these separate components of variability, a significant proportion of the total measurement uncertainty can be explained by the counting statistics.

The B-C032 fuel assenbly was selected as our "standard" fuel assembly. It was mensured on each of the 5 days during wich measurementa were performed (Table B-V). An uncertainty of 2-3* was obtained for the neutron meanrenents and 1.48 for the ion chamber manuremento. This fuel assenbly will also be measured during future exercises at GEmorrie to determine measurement reproducibility over extended time perlods (several months). 
TAMT: a-IV

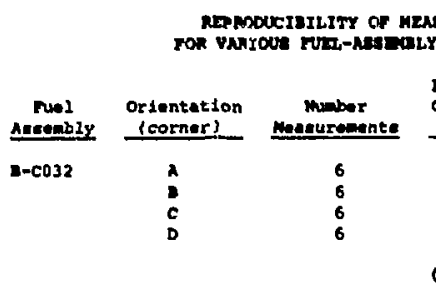

2- $\cos 6$

A
C
D

$n$
$c$
0

C-DN201

12
12
6
12
GDorarare

\begin{tabular}{|c|c|}
\hline $\begin{array}{c}\text { Tiasion } \\
\text { Chenber } \\
(4)\end{array}$ & $\begin{array}{c}\text { Ion } \\
\text { chavber } \\
\text { (1) }\end{array}$ \\
\hline $\begin{array}{l}0.89 \\
0.50 \\
0.84 \\
0.35 \\
0.60 \\
(0.86)^{6}\end{array}$ & $\begin{array}{l}0.48 \\
0.19 \\
0.68 \\
0.43 \\
0.45\end{array}$ \\
\hline
\end{tabular}

Fienton

Chumber (e)

0.73

1.46

0.59

1.39

1.04

1.77

2.56

1.07

$\frac{1.08}{1.62}$

$\frac{1.00}{1.62}$

1.19

1.52

0.46

$\frac{0.48}{0.91}$

2.80

3.78

0.65

0.77

$\frac{0.77}{2.00}$

$(0.81)^{b}$

\subsection{4}

0.45

1.15

$\frac{1.23}{0.97}$

0.44

0.25

1.35

1.46

1.94

$\frac{1.61}{(1.21) b}$

$(0.83)^{b}$

$\frac{0.76}{0.52}$

8.29 1.31

5.52

10.74

1.05

$\frac{6.29}{7.71} \quad \frac{1.32}{1.00}$

$(4.36) b$

\subsection{8}

5.26

9.38

$\frac{0.11}{7.16}$

$(7.27)^{b}$

Tilaxion chanber from ve $(Y, n)$ detector.

bEutimated uncertainty cauged by counting atatistica.

During this measurement exercise, we monitored the backgrounds for each of the three detectors. The results for 108 background measurements are shown in Table B-VI. As in Table B-IV, the variation caused by counting statistics is of the same magnitude as the actual measured variation.

The experimental measurements show that reproducible measurericints can be obtained using the presently designed v-shaped positioning fixture. Counting. statistics appear to be the major source of variation in the measurements. After this was established, we proceeded with the investigation of the other objectives.

\section{B. Angular Effects}

The second objective was to quantify angliar burnup effects by measuring different corners of the spent-fuel assemblies. The results of the reproducibility studies were combined with additional measurements made on all 17 spent-fuel assemblies. The results are given in Table B-VII, The neutron enission rate can vary by 30-408, depending on the specific corner measured. Similar variability is observed in the ion chamber resuits.
TALE I-V

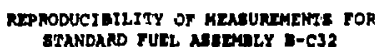

\begin{tabular}{|c|c|c|c|}
\hline Dute & $\begin{array}{c}\text { Fiadion Chember } \\
\text { (counte/e) }\end{array}$ & Ion chupuer & $\begin{array}{c}\text { Tilelon Chanber } \\
\text { (counte/e) }\end{array}$ \\
\hline $10 / 30 / 80$ & $\begin{array}{l}175.9 \\
174.2 \\
174.6 \\
274.7 \\
174.9 \\
\frac{174.2}{174.76} \pm 0.6\end{array}$ & $\begin{array}{l}421 \\
419 \\
416 \\
41 \\
417 \\
\frac{419}{418}=1.8\end{array}$ & $\begin{array}{l}75.0 \\
76.1 \\
75.8 \\
74.1 \\
75.4 \\
\frac{77.4}{75.78} \pm 1.05\end{array}$ \\
\hline $10 / 31 / 80$ & $\begin{array}{l}167.0 \\
162.8\end{array}$ & 41: & $\begin{array}{l}72.1 \\
73.4\end{array}$ \\
\hline $11 / 1 / 80$ & $\begin{array}{l}170.9 \\
175.6\end{array}$ & $\begin{array}{l}116 \\
416\end{array}$ & $\begin{array}{l}74.7 \\
75.3\end{array}$ \\
\hline $11 / 2 / 80$ & $\begin{array}{l}163.5 \\
170.2 \\
170.6 \\
168.6\end{array}$ & $\begin{array}{l}399 \\
411 \\
411 \\
111\end{array}$ & $\begin{array}{l}68.2 \\
71.9 \\
71.5 \\
72.1\end{array}$ \\
\hline $\begin{array}{l}\text { Iean } \\
\text { Std Dev }\end{array}$ & $\begin{array}{l}172.2 \\
171.1 \\
171.3 \\
171.3 \\
4.0(2.34)\end{array}$ & $\begin{array}{l}420 \\
420 \\
\frac{420}{415} \\
5.6(1.44)\end{array}$ & $\begin{array}{l}76.1 \\
75.1 \\
74.3 \\
74.0 \\
2.3(3.14)\end{array}$ \\
\hline
\end{tabular}

Giasion chamber from the be $\{Y, n\}$ detector.

Because the measurement reproducibility for precision) is much better than this, the angular effects appear to be real.

The results from these angular effects messurements are presented in Figs. B-6 through B-g for reactors $A, B, C$, and $D$, respectively. The data were corrected for the decay of ${ }^{244} \mathrm{~cm}$ (t $=$ $18.11 \mathrm{yr}$ ) because of the differences in cooling timos. No co:rection was included for the ${ }^{242} \mathrm{~cm}$ decay because its contribution to the measured neutron rates was insignificant. The shortest: cooling time was 1340 days for fuel assemblies B-c056 and B-c052. Curium-242 has a half-life of 162.8 days, therefore ${ }^{24 / C} \mathrm{Cm}$ has decayed by $a$ factor of 0.003 .

The meximum variability of the measurements for eacheof the four corners for the 17 fuel assemblies is given in Table.B-VIII. Each of the data sets frcin the PWR fuel assemblies had a maximum difference of 2408 for at least one fuel assembly. This high variability does not appear to be related to just a single reactor but rather may bo a general characteristic of PWR fuel assemblies. The 185 differfance found in the BWR fuel assembly was not unexpected because of the cruciform control blades used in BWRs. 
TABLE B-VI

BACKGROUND MEASUREMENTS

\begin{tabular}{|c|c|c|c|c|c|}
\hline \multirow[b]{2}{*}{ Dute } & \multirow[b]{2}{*}{ Tine } & \multirow[b]{2}{*}{$\begin{array}{c}\text { Number of } \\
\text { Measurement: }\end{array}$} & \multicolumn{3}{|c|}{ Avarage Valuea } \\
\hline & & & $\begin{array}{c}\text { Fisetion } \\
\text { Chamber } \\
\text { (counte/e) } \\
\end{array}$ & $\begin{array}{c}\text { Ion } \\
\text { Chamber }\end{array}$ & $\begin{array}{c}\text { Fiasion } \\
\text { Chambera } \\
\text { (counta/a) } \\
\end{array}$ \\
\hline $10 / 29 / 80$ & $16: 21-16: 25$ & 3 & 1.05 & -7.7 & \\
\hline $10 / 30 / 80$ & $\begin{array}{l}\theta: 11-\theta: 52 \\
12: 20-12: 41 \\
14: 21-14: 25 \\
16: 36\end{array}$ & $\begin{array}{l}6 \\
5 \\
2 \\
1\end{array}$ & $\begin{array}{l}1.07 \\
1.05 \\
0.95 \\
1.00\end{array}$ & $\begin{array}{l}-8.0 \\
-8.0 \\
-8.0 \\
-8.0\end{array}$ & $\begin{array}{l}0.21 \\
0.23 \\
0.18\end{array}$ \\
\hline $\begin{array}{l}10 / 30 / \mathrm{BC}- \\
10 / 31 / 80\end{array}$ & $16: 38-7: 53$ & 69 & 1.02 & -8.0 & 0.21 \\
\hline $10 / 31 / 80$ & $8: 25-8: 37$ & 7 & 1.02 & -8.0 & 0.20 \\
\hline $11 / 1 / 80$ & $\begin{array}{l}7: 47-7: 52 \\
8: 26-8: 28 \\
27: 36\end{array}$ & $\begin{array}{l}3 \\
2 \\
1\end{array}$ & $\begin{array}{l}1.05 \\
1.08 \\
0.92\end{array}$ & $\begin{array}{l}-8.0 \\
-8.0 \\
-8.0\end{array}$ & $\begin{array}{l}0.18 \\
0.22 \\
0.27\end{array}$ \\
\hline $11 / 2 / 80$ & $\begin{array}{l}10: 55 \\
15: 07 \\
16: 39 \\
17: 29 \\
18: 29 \\
19: 25 \\
20: 27\end{array}$ & $\begin{array}{l}1 \\
1 \\
1 \\
1 \\
1 \\
1 \\
1\end{array}$ & $\begin{array}{l}1.08 \\
1.07 \\
0.92 \\
0.90 \\
0.96 \\
1.08 \\
0.85\end{array}$ & $\begin{array}{r}-8.0 \\
-10.0 \\
-10.0 \\
-8.0 \\
-8.0 \\
-8.0 \\
-8.0\end{array}$ & $\begin{array}{l}0.23 \\
0.20 \\
0.23 \\
0.19 \\
0.15 \\
0.15 \\
0.15\end{array}$ \\
\hline $11 / 3 / 80$ & $10: 13-10: 14$ & $\underline{2}$ & 0.02 & $-B .0$ & 0.24 \\
\hline \multicolumn{2}{|c|}{ Weighted average } & 108 & $1.02 \pm 0.07$ & $-B .0$ & $0.21 \pm 0.04$ \\
\hline \multicolumn{2}{|c|}{ Precision } & & 7 & & 191 \\
\hline \multicolumn{2}{|l|}{ Range: } & & $0.85-1.08$ & -7.0 to -10.0 & $0.25-0.24$ \\
\hline \multicolumn{3}{|c|}{ Uncertainty caused by cou } & $=\quad 102$ & & 221 \\
\hline
\end{tabular}

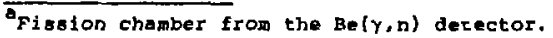

TABLE B-VII

NORMALIZED RESPONSES FOR EACH OF THE SPENT-FUEL ASSEMBLIES

\begin{tabular}{|c|c|c|c|c|}
\hline $\begin{array}{c}\text { Fuel } \\
\text { Assembly }\end{array}$ & $\begin{array}{l}\text { orientation } \\
\text { (corner) }\end{array}$ & $\begin{array}{c}\text { Fission Chamber } \\
\text { (counte/e) }\end{array}$ & Ion Chanber & $\begin{array}{c}\text { Fission Chanbera } \\
(\text { counte/s) }\end{array}$ \\
\hline A-2019 & $\begin{array}{l}A \\
B \\
C \\
D\end{array}$ & $\begin{array}{l}1.00 \\
1.02 \\
1.02 \\
0.99\end{array}$ & $\begin{array}{l}1.00 \\
1.01 \\
1.03 \\
1.02\end{array}$ & $\begin{array}{l}1.00 \\
1.03 \\
1.02 \\
0.99\end{array}$ \\
\hline$A-\operatorname{Co49}$ & $\begin{array}{l}A \\
B \\
C \\
D\end{array}$ & $\begin{array}{l}1.00 \\
0.63 \\
0.60 \\
0.97\end{array}$ & $\begin{array}{l}1.00 \\
0.57 \\
0.51 \\
0.95\end{array}$ & $\begin{array}{l}1.00 \\
0.62 \\
0.59 \\
0.94\end{array}$ \\
\hline A-A045 & $\begin{array}{l}A \\
B \\
C \\
D\end{array}$ & $\begin{array}{l}1.00 \\
1.03 \\
1.02 \\
0.94\end{array}$ & $\begin{array}{l}1.00 \\
1.01 \\
1.04 \\
0.98\end{array}$ & $\begin{array}{l}1.00 \\
1.04 \\
1.03 \\
0.93\end{array}$ \\
\hline A-8012 & $\begin{array}{l}A \\
B \\
C \\
D\end{array}$ & $\begin{array}{l}1.00 \\
1.04 \\
0.98 \\
1.00\end{array}$ & $\begin{array}{l}1.00 \\
1.02 \\
0.97 \\
0.99\end{array}$ & $\begin{array}{l}1.00 \\
1.02 \\
0.96 \\
0.99\end{array}$ \\
\hline
\end{tabular}


TABLE B-VII (cont.)

\begin{tabular}{|c|c|c|c|c|}
\hline $\begin{array}{c}\text { Fuel } \\
\text { Aesembly }\end{array}$ & $\begin{array}{l}\text { orientation } \\
\text { (cornes) } \\
\end{array}$ & $\begin{array}{l}\text { Figaion Chamber } \\
\text { (counte/s) }\end{array}$ & Ion Chamber & $\begin{array}{c}\text { Fiesion Chanber } \\
\text { (counte/a) }\end{array}$ \\
\hline$B-\cos 6$ & $\begin{array}{l}\mathrm{A} \\
\mathrm{B} \\
\mathrm{C} \\
\mathrm{D}\end{array}$ & $\begin{array}{l}1.00 \\
1.03 \\
0.98 \\
0.91\end{array}$ & $\begin{array}{l}1.00 \\
1.01 \\
1.01 \\
0.93\end{array}$ & $\begin{array}{l}1.00 \\
1.02 \\
0.98 \\
0.92\end{array}$ \\
\hline$B-C 032$ & $\begin{array}{l}\mathbf{A} \\
\mathrm{B} \\
\mathbf{C} \\
\mathbf{D}\end{array}$ & $\begin{array}{ll}1.00 & (1.00) b \\
0.72 & (0.72) \\
0.85 & (0.84) \\
1.25 & (1.22)\end{array}$ & $\begin{array}{ll}1.00 & (1.00) \\
0.70 & (0.70) \\
0.83 & (0.83) \\
1.12 & (1.12)\end{array}$ & $\begin{array}{ll}1.00 & (1.00) \\
0.74 & (0.71) \\
0.86 & (0.82) \\
1.24 & (1.19)\end{array}$ \\
\hline$B-\cos 2$ & $\begin{array}{l}\mathbf{A} \\
\mathrm{B} \\
\mathbf{C} \\
\mathrm{D}\end{array}$ & $\begin{array}{l}1.00 \\
0.95 \\
1.37 \\
1.30\end{array}$ & $\begin{array}{l}1.00 \\
0.85 \\
1.22 \\
1.24\end{array}$ & $\begin{array}{l}1.00 \\
0.95 \\
1.35 \\
1.31\end{array}$ \\
\hline C.DN201 & $\begin{array}{l}\text { A } \\
B \\
C \\
D\end{array}$ & $\begin{array}{l}1.00 \\
0.90 \\
0.82 \\
0.89\end{array}$ & $\begin{array}{l}1.00 \\
0.98 \\
0.92 \\
0.86\end{array}$ & $\begin{array}{l}1.00 \\
0.89 \\
0.75 \\
0.87\end{array}$ \\
\hline$D-\lambda 051$ & $\begin{array}{l}\text { A } \\
\mathrm{B} \\
\mathrm{C} \\
\mathrm{D}\end{array}$ & $\begin{array}{l}1.00 \\
0.97 \\
1.07 \\
1.00\end{array}$ & $\begin{array}{l}1.00 \\
0.96 \\
1.03 \\
1.01\end{array}$ & $\begin{array}{l}1.00 \\
0.97 \\
1.08 \\
1.03\end{array}$ \\
\hline$D-C 004$ & $\begin{array}{l}\text { A } \\
B \\
C \\
D\end{array}$ & $\begin{array}{l}1.00 \\
0.77 \\
0.90 \\
1.21\end{array}$ & $\begin{array}{l}1.00 \\
0.83 \\
0.90 \\
1.11\end{array}$ & $\begin{array}{l}1.00 \\
0.77 \\
0.88 \\
1.19\end{array}$ \\
\hline D-D001 & $\begin{array}{l}\mathrm{A} \\
\mathrm{B} \\
\mathrm{C} \\
\mathrm{D}\end{array}$ & $\begin{array}{l}1.00 \\
1.00 \\
1.05 \\
1.03\end{array}$ & $\begin{array}{l}1.00 \\
0.99 \\
1.02 \\
1.02\end{array}$ & $\begin{array}{l}1.00 \\
1.00 \\
1.06 \\
1.03\end{array}$ \\
\hline D-COO1 & $\begin{array}{l}\mathbf{A} \\
\mathbf{B} \\
\mathbf{C} \\
\mathbf{D}\end{array}$ & $\begin{array}{l}1.00 \\
1.16 \\
0.89 \\
0.76\end{array}$ & $\begin{array}{l}1.00 \\
1.09 \\
0.92 \\
0.80\end{array}$ & $\begin{array}{l}1.00 \\
1.16 \\
0.90 \\
0.78\end{array}$ \\
\hline$D-\$ 036$ & $\begin{array}{l}\mathrm{A} \\
\mathrm{B} \\
\mathrm{C} \\
\mathrm{D}\end{array}$ & $\begin{array}{l}1.00 \\
0.94 \\
0.89 \\
0.95\end{array}$ & $\begin{array}{l}1.00 \\
0.98 \\
0.93 \\
0.95\end{array}$ & $\begin{array}{l}1.00 \\
0.95 \\
0.89 \\
0.94\end{array}$ \\
\hline$D-D 020$ & $\begin{array}{l}\boldsymbol{A} \\
\mathbf{B} \\
\mathbf{C} \\
\mathbf{D}\end{array}$ & $\begin{array}{l}1.00 \\
0.87 \\
0.72 \\
0.85\end{array}$ & $\begin{array}{l}1.00 \\
0.94 \\
0.76 \\
0.90\end{array}$ & $\begin{array}{l}1.00 \\
0.89 \\
0.74 \\
0.87\end{array}$ \\
\hline$D-1009$ & $\begin{array}{l}\text { A } \\
B \\
\text { C } \\
\text { D }\end{array}$ & $\begin{array}{l}1.00 \\
0.99 \\
1.01 \\
0.96\end{array}$ & $\begin{array}{l}1.00 \\
0.99 \\
1.00 \\
0.97\end{array}$ & $\begin{array}{l}1.00 \\
0.99 \\
1.03 \\
0.97\end{array}$ \\
\hline$D-D 046$ & $\begin{array}{l}A \\
B \\
C \\
D\end{array}$ & $\begin{array}{l}1.00 \\
0.92 \\
1.00 \\
1.05\end{array}$ & $\begin{array}{l}1.00 \\
0.95 \\
0.98 \\
1.02\end{array}$ & $\begin{array}{l}1.00 \\
0.93 \\
0.98 \\
1.06\end{array}$ \\
\hline $\mathrm{D}-\mathrm{C} 020$ & $\begin{array}{l}A \\
\mathbf{B} \\
C \\
D\end{array}$ & $\begin{array}{l}1.00 \\
1.14 \\
1.32 \\
1.18\end{array}$ & $\begin{array}{l}1.00 \\
1.08 \\
1.18 \\
1.11\end{array}$ & $\begin{array}{l}1.00 \\
1.11 \\
1.28 \\
1.15\end{array}$ \\
\hline
\end{tabular}

dFision chanber from the $B e(\gamma, n)$ detector.

bNumber in parentheses are for a second set of data taken at the end of the exercise. 


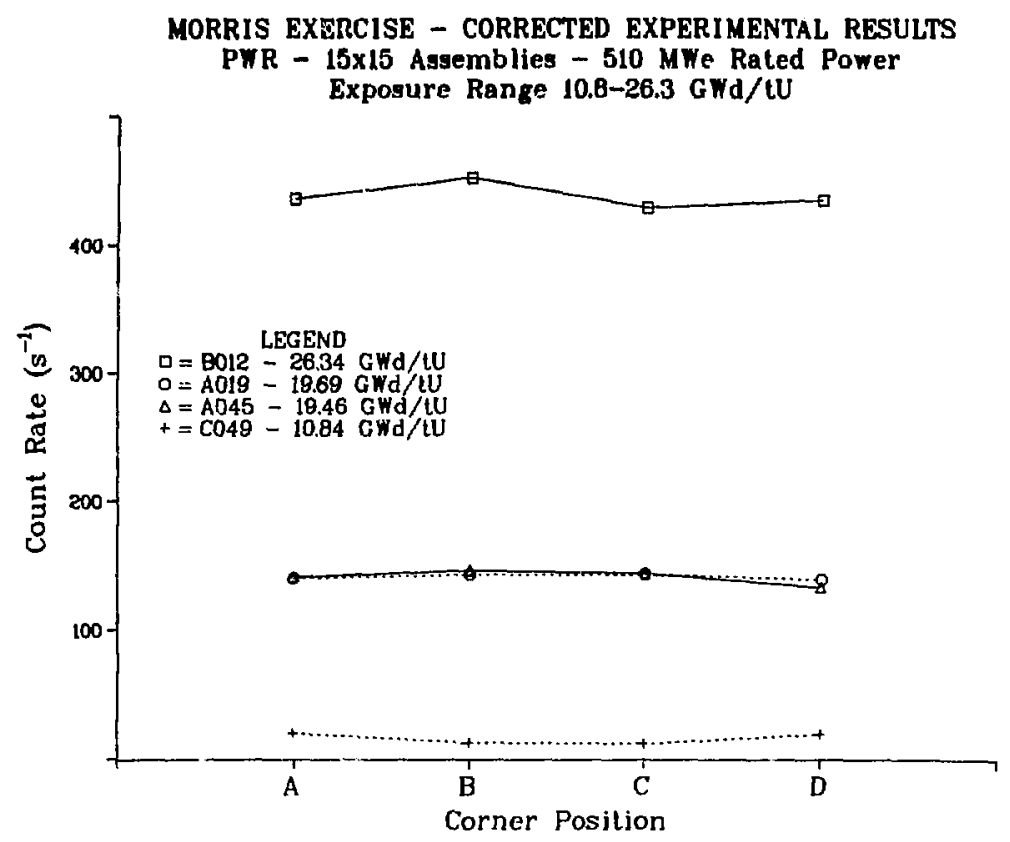

Fig. B-6.

Relative neutron emission rates as a finction of the four corner positions for fuel assemblies from Reactor $A$.

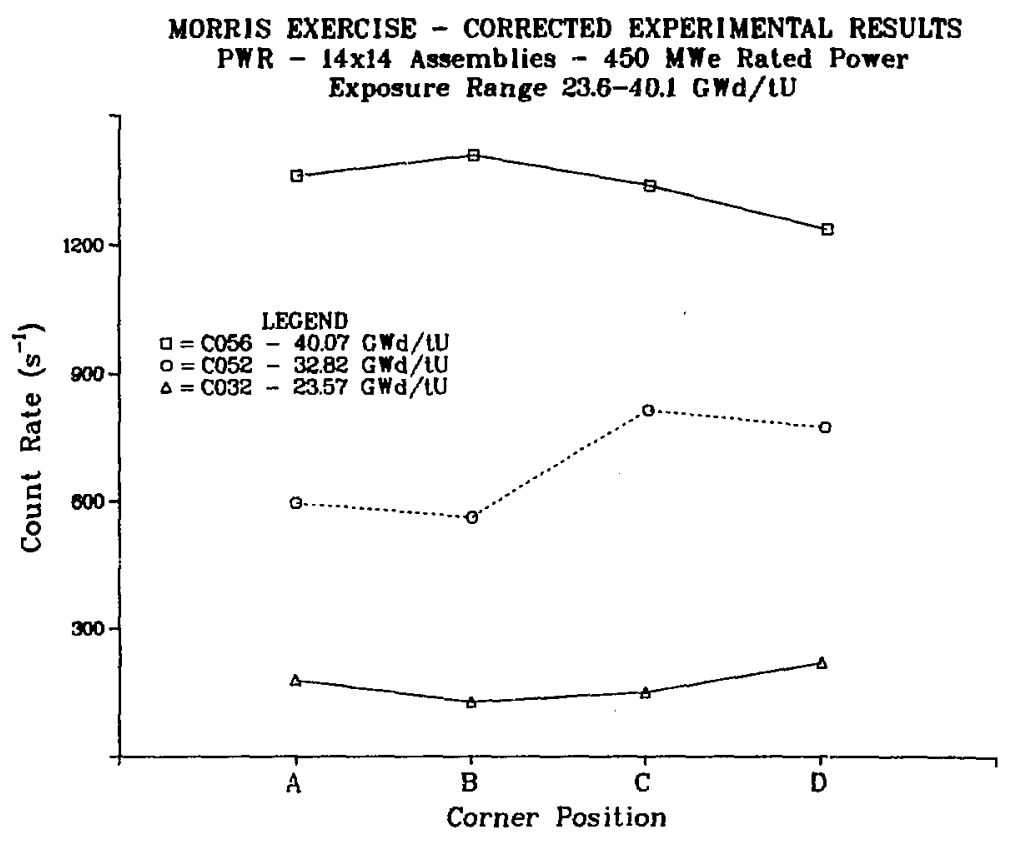

Fig. B-7.

Relative neutron eniasion rates as function of the four corner positions for fuel assemblies fron Reactor B. 

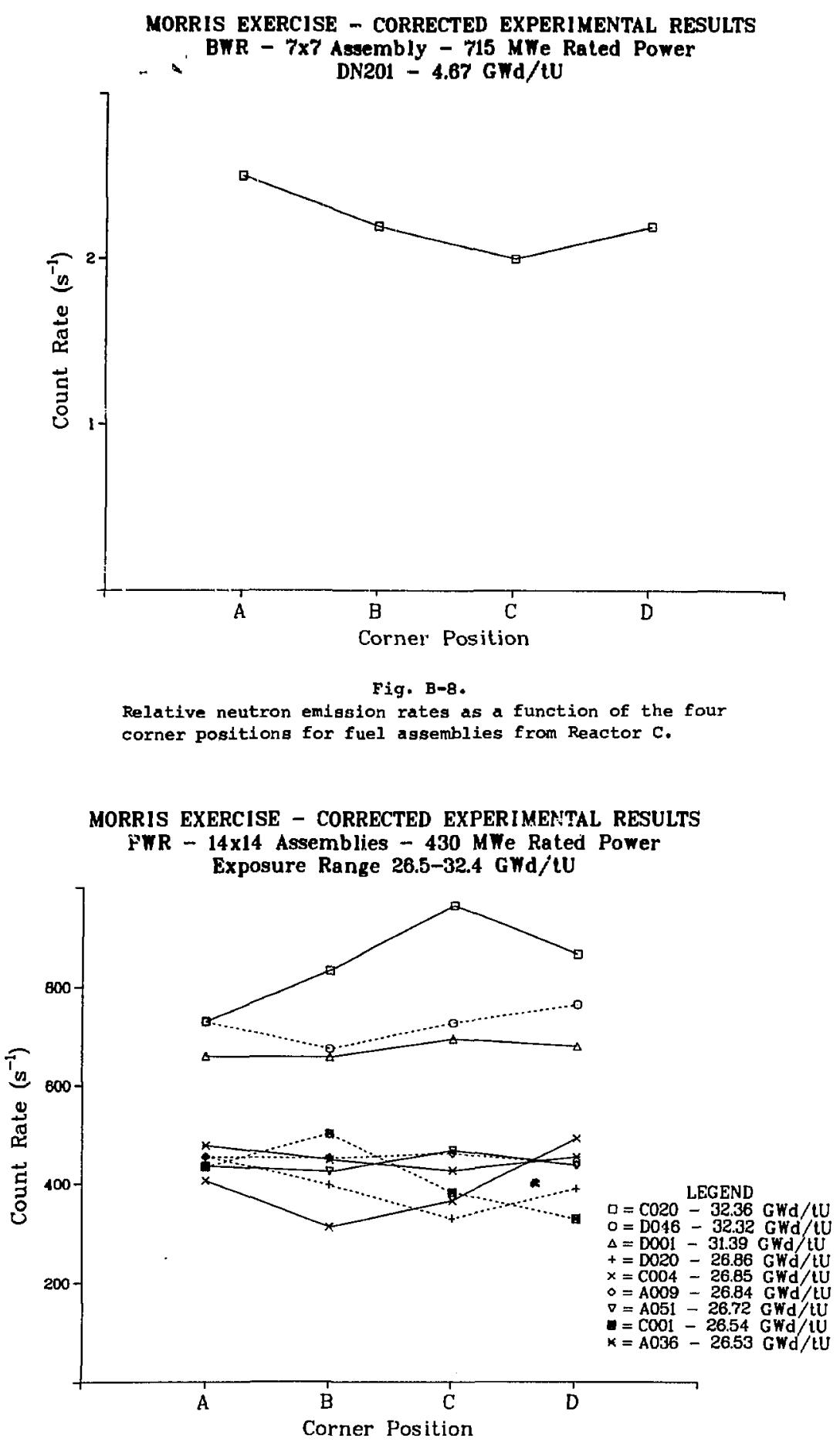

Fig. B-9.

Relative neutron emission rates as a function of the four corner positions for fuel assemblies from Reactor D. 
TABLI B-VIII

MAXIMLN DIFFERENCES IN THE MRASUREMENTS AT THE FOUR CORNER POSITIONS

$\begin{array}{lr} & \text { Maximum Difference } \\ \text { Fuel Assembly } & 3 \\ A-\lambda 019 & 37 \\ A-C 049 & 9 \\ A-A 045 & 6 \\ A-B 012 & \\ B-C 056 & 12 \\ B-C 032 & 31 \\ B-C 052 & 42 \\ \text { C-DN201 } & \\ \text { D-A051 } & 18 \\ D-C 004 & \\ D-D 001 & 9 \\ D-C 001 & 36 \\ D-A 036 & 34 \\ D-D 020 & 11 \\ D-A 009 & 28 \\ D-D 046 & 5 \\ D-C 020 & 12 \\ & 24\end{array}$

The results shown in Fig. B-7 exhibit changes ranging from 12-428 between the corners of the fuel assembly. The irradiation history of each of the fuel assemblies in the reactor were determined and are listed in Table B-IX. A schematic of the reactor core is given in Fig. B-10 with the specific angular orientation of each fuel assembly. In this core, the fuel assemblies cannot be rotated. As can be seen from Table B-VII and Fig. $B-10$, the corners with the lowest relative neutron rates were always on the periphery of the reactor core. This effect appears to persist even after the fuel assembly is moved to an interior position, as was the history of fuel assembly C-052. From this data, it would appear that the itrst cycle of a PWR fuel assemhly defjnes a gradient that persists through the irradiation history.

\section{Empirira] Correlations}

Data for the Emir corners were summed for each fuel assembly and were corrected for the decay of $244 \mathrm{~m}$. These results are plotted in Fig. B-1l for each of the three PWR data sets. The parameters for the best fits of the porer functional relationship are given in Table $B-X$. The number of fuel assemblies measured was 1 imited, as well

TABLE B-IX

INDIVIDUAL IRRADIATION HISTORIES OF EUEL ASSEHLINS

\begin{tabular}{|c|c|c|c|}
\hline Fuel Assenbly & Core Position & \multicolumn{2}{|c|}{$\begin{array}{l}\text { Average Exposure } \\
\text { (GNd/tU) }\end{array}$} \\
\hline \multirow[t]{3}{*}{$\cos 2$} & $F-1$ & & 10.80 \\
\hline & $D-4$ & & 12.77 \\
\hline & & Total & 23.57 \\
\hline \multirow[t]{4}{*}{$\mathrm{co56}$} & $k-10$ & & 17.13 \\
\hline & $c-5$ & & 13.34 \\
\hline & $c-5$ & & 9.60 \\
\hline & & Total & 40.07 \\
\hline \multirow[t]{4}{*}{$\cos 2$} & $A-8$ & & 11.23 \\
\hline & $F-2$ & & 12.75 \\
\hline & $F-2$ & & 8.84 \\
\hline & & Total & 32.87 \\
\hline
\end{tabular}

PWR Grid for $14 \times 14$ Assemblies

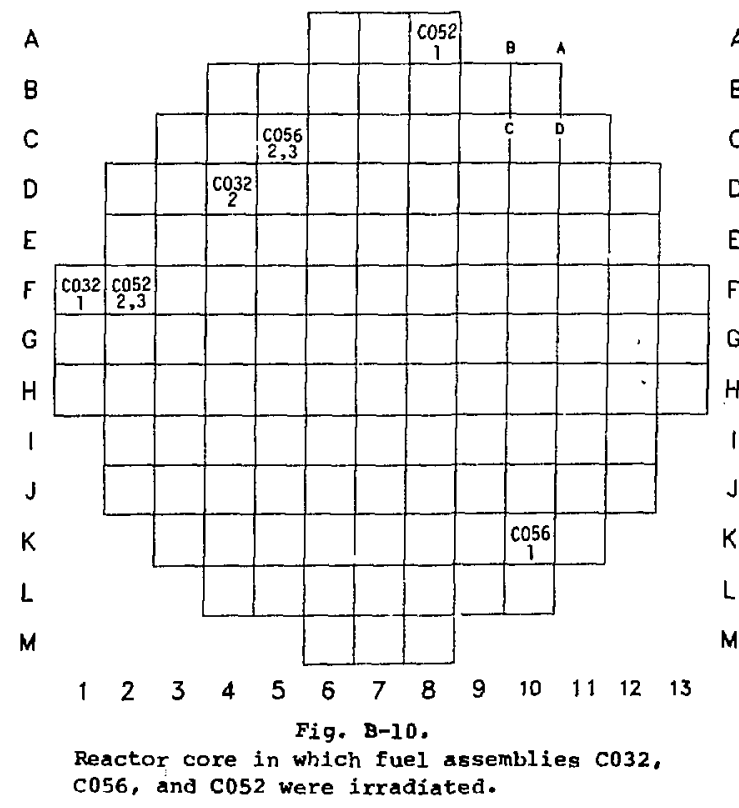




\section{MEASURED NEUTRON RATE}

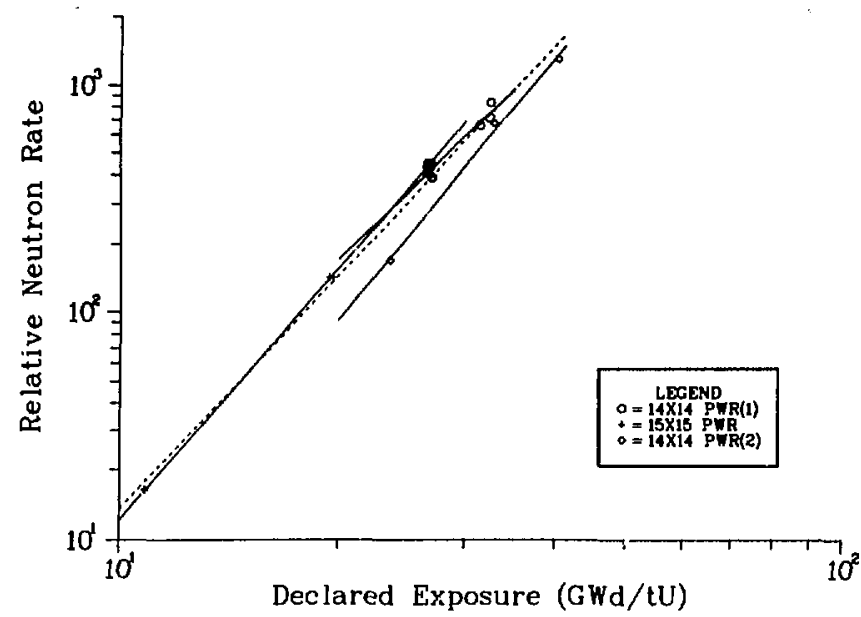

Fig. B-11.

Data from the three PWR data sets with the individual power functions (best fit) and the collective results (dashed line).

TABLE B-X

POWER FUNCTIONS FOR PWR MEASUREMEN'CS ${ }^{a}$

\begin{tabular}{|c|c|c|c|}
\hline $\begin{array}{l}\text { Reactor } \\
\text { Data Set }\end{array}$ & $\begin{array}{c}\text { Scaling Factor } \\
(\alpha) \\
\end{array}$ & $\begin{array}{l}\text { Exponent } \\
\text { (B) } \\
\end{array}$ & $\begin{array}{c}\text { Correlation Coefficient } \\
\left(R^{2}\right)\end{array}$ \\
\hline A & 7.75 E-12 & 3.10 & 0.04 \\
\hline B & $2.23 \quad E-14$ & 3.68 & 0.99 \\
\hline$c$ & $1.43 \quad E-15$ & 3.91 & 0.99 \\
\hline$A+B+C$ & 2.71 E-13 & 3.42 & 0.98 \\
\hline
\end{tabular}

as the range of exposures, but the data appear to be consistent with measured and calculated results obtalned previously.

D. Fuel Assembly Geometry

We could not determine any significant differences between the PWR fuel assemblies with 15 by 15 and 14 by 14 arrays. Figure B-12 shows a comparison of the results from the 15 by 15 fuel assemblies (c056 and $\operatorname{co52}$ ) and the 14 by 14 fuel assemblies $(C 020, D 046$, and D001). The data are insufficient to draw any specific conclusions; however, it can be noted that the results are similar for fuel assemblies with approximately the same exposures.
E. Conclusions

The primary conclusions that can be drawn to date are:

(1) Spent-fuel assemblies can be positioned for measurement using the V-shaped positioning mechanism to obtain reproducible results, For neutron measurements the precision is 1-28, and for gross gamma measurements the precision is better (21). A significant part of the uncertainty associated with the neutron measurements is associated with the counting statistics. 
MORRIS EXERCISE - CORRECTED EXPERIMENTAL RESULTS

Comparison of Assemblies with Similar Exposures

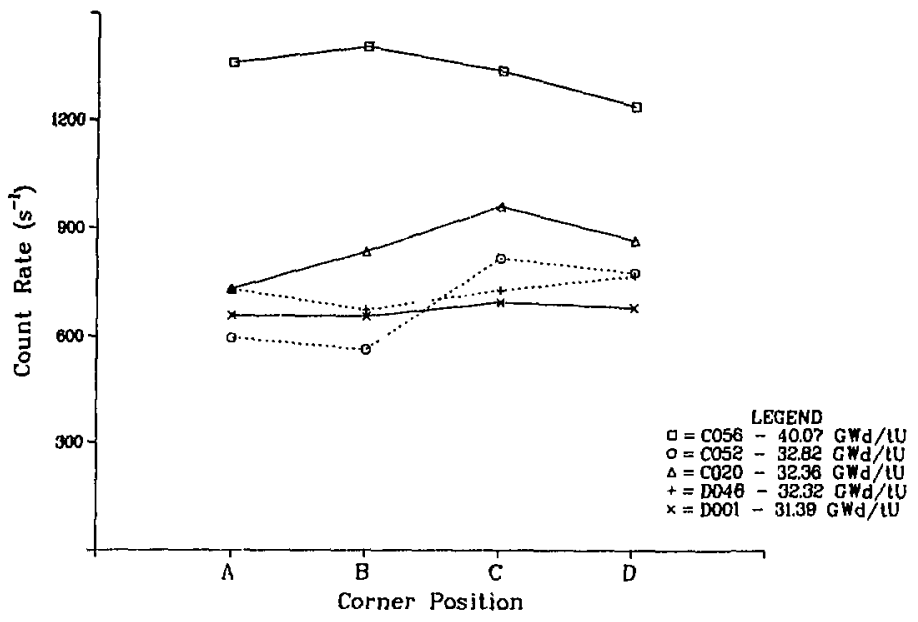

Fig. B-12.

Comparison of results from 15 by 15 (C056 and $\cos 2$ ) fuel assemblies with 14 by 14 (C020, D046, and DOO1) fuel assemblies.

(2) Angular orientation of spent-fuel assem-

However, only a small number of fuel blfes can have a wigntficant effect on assemblies were examined from each reacpassive neutron and gamma-ray measurements with variations of $30-408$ found for both types of measurements. The source of these variations appears to be real differences in burnup caused by the position of the fuel assembly in the reactor core.

(3) Power function relationships appear to relate the measured neutron count rate to the operator-declared values of exposure. tor, and therefore, a general conclusion must be deferred until we have collected additional data.

(4) We were unable to detect any significant difference between 14 by 14 and 15 by 15 PWR fuel assembly geometries. Again, it must be noted that only a small amount of data has been collected. 


\section{APPENDIX C}

BIBLICGRAPHY ON SPENT-FUEL MEASUREMENTS

TO APRIL 1, 1981

S. L. Klein

Safeguards Systems Group Q-4

1. G. Adiletta, N. Benatti, R. Guidotti, M. Paoletti Gualandi, P. Peroni, A. M. Bresesti, $M$. Bresesti, and D. D'Adamo, "Investigations on Ridioactive Fission Product Correlations: Gama Spectrometry Measurements on Spent Fuel Assemblies of the Garigliano Reactor," Joint Nuclear Research Centre (Ispra) report EUR5928e (1974).

2. Advisory Group Meeting on the Nondestructive Analysis of Irradiated Power Reactor Fuel, International Atomic Energy Agency report AG-11 (Apr11 4-7, 1977).

3. Advisory Group Meeting on Methods and Techniques for NDA Safeguards Measurements of Power Reactor Spent Fuel, International Atomic Energy Agency report AG-241 (October 29-November 2, 1979).

4. V. H. Allen and A. J. Stirling, "Performance of a Prototype Spent Fuel Bundle Counter for 600 NW CANDU Reactors," Nucl. Mater. Manage. VIII, 733-743 (1979).

5. A. Ariemma, I. Bramat1, M. Galliani, M. Paoletti Gualandi, B. Zaffiro, A. Cricchio, and L. Koch, "Experimental and Theoretical Determination of Burnup and Heavy Isotope Content in a Fuel Assembly Irradiated in the Garigliano Boiling Water Reactor," Ente Nazionlae per l'Energia Electtrica-Rome (Italy) report EUR-4638e (1971).

6. R. H. Augustson, C. N. Henry, and C. R. Weisbin, Measurement of the Uranium-235 Content in a Spent MTR Fuel Element Using the Delayed-Neutron Yield Technique," Nucl. Technol. 4, 197-199 (1972).

7. R. Bannella, A. Giuriato, M. Paolett1 Gualandi, A. M. Bresesti, M. Bresesti, D. D'Adamo, "Relative Measurements of Burnup and Plutonium Content in PWR Assemblies," Trans. Am. Nucl. Soc. 15, 681-682 (1972).

8. P. Barbero, G. Bidoglio, M. Bresesti, R. Chevalier, et al., "Post-Irradiation Exam1nation of Fuel Discharged from the TRINO vercellese Reactor after the 2nd Irradiation Cycle," Commission of European Communities report EUR 5605e (1976).

9. P. Barbero, et al., "Post-Irradiation Analysis of the Grundremingen BNR Spent Fuel," Buratom report EUR 630len (1979).
10. P. Barbero, et al., "Post-Irradiation Aralysis of the Obrigheim PWR Spent Fuel," Euratom report EUR 6589en (1979).

11. C. Beets, P. Bemelmans, and R. Pirard, "Gamma Measurements on SENA Spent Fuel Assemblies and Dissolver Solutions," Contributions to the Joint Safeguards Experiment $\mathrm{Nol}$ IV at the Eurochemic Reprocessing Plant, Mol, Belgium, report BLG-486 (September 1973).

12. C. Beets, P. Bemelmans, T. Dragnev, and R. Hecq, "Gamma Measurements on Spent Fuel Elementg," Trans. Am. Chem. Soc. 15, 673-674 (1972).

13. T. R. Benent and J. R. Phillips, "Evaluation of Relative Detection Efficiency on Sets of Irradiated Fuel Elements," in Proc. of the 1980 DOE statistical Symposium, Compiled and Edited by Tykey Truett, David Margolies, and Richard W. Mensing, October 29-31, 1980, Berkeley, California, CONF-801045 (April 1981).

14. N. Beyer, M. de Carolis, E. Dermendjiev, A. Keddar, and D. Rundquist, "IAEA NDA Measurements as Applied to Irradiated Fuel Assemblies," in Nuclear Safeguards Technology 1978, Proc. Symp., Vienna, October 2-6, 1978 (International Atomic Energy Agency, Vienna, 1979), IAEA-SM-231/106, Vol. I, PP. 443-457.

15. D. G. Boase, J. D. Chen, "Nondestructive Analysis of Irradiated CANDU Fuels," Atomic Energy of Canada Limited report AECL-6316 (February 1979).

16. D. G. Boase, J. D. Chen, and L. T. Felawka, "Gamma Spectrometry of Irradiated Reactor Fuels, Sxperience at the Whiteshell Nuclear Research Establishment," Atomic Energy of Canada Limited report AECL-3952 (October 1971).

17. G. E. Bosler and J. R. Phillips, "Neutron Sources in Spent-Fuel Assemblies and Their Dependence on Irradiation Parameters," Trans. ANS $35,120(1980)$.

18. P. Brand, A. Cricchio, and L. Koch, "Feasihility study of the Use of Radioactive Fission Froduct Correlations for the Determination of Burnup and heavy Isotopes Composition of BWR Dodewaard Fuel," Joint Nuclear Research Centre report EUR-4909e (1972). 
19. A. M. Bresenti, M. Bresesti, S. Facchotti, F. Hansone, P. Barbero, C. Cerutti, F. Marell, A. Pell, R. Pletra, R, Klersy, h. $_{0}$ Schurenkamper, A. Frigo, E. Ghezil, J. P. Moerschman, A. Pollicint, K. H. Schrader, J. Biteau, A. Cricchlo, and I. Koch, "PostIrradiation Analysis of Trino Vercelles Reactor Fuel Ilements," Joint Nuclear Research Centre (ISPRA and Karlsruhe) report EUR-4909e (1975).

20. A. M. Bresest1, M. Breseati, M. Cuypera, D. D'Adamo, L. Lezzoli, R. Bannella, A. Giurlato, M. Paoletti Gualandi, and P. Peroni, "Investigation on Radioactive Fission Product Correlationa: Gama Spectrometry Measurements on Spent Fuel Assemblies Discharged from the Trino Vercellese Reactor at the End of the 2nd Irradiation Cycle," Joint Nuclear Research Centre (ISPRA) and Ente Nazionale per l'Energie Elettrica-Rome (Italy) report EUR-5334e (1975).

2I. J. D. Chen, D. G. Boase, and R. B. Lypka, "Nondestructive Determination of Burnup by Gauma Scanning: An Assesament of $144 \mathrm{Ce} / \mathrm{Pr}$ as a Fission Monitor in Candu Fuels," Atomic Energy of Canada Iimited report AECL-5236 (January 1976).

22. J, D, Chen, et al., "Nondestructive Determination of Eurnup by Gamma Scanning: An Assessment of Cesium-134/Cesium-137 Activity Ratio as a Fission Monitor in Candu Fuels," Atomic Energy of Canada Limired report AECL6192 (August 1978).

23. D. E. Chrigtensen, "Collection and Aralysis of Measured Fission Product Data," U.S. Arms Control and Disarmament Agency report (unnumbered) (March 1979).

24. D. D. Cobb, H. A. Dayem, and R. J. Dietz, "Preliminary Concepts: Safeguards for Spent Light-Water Reactor Fuels," Los Alamos Scientific Lahoratory report LA-7730-MS (1979).

25. D. D. Cobb, Ed., "Spent-Fuel Storage Facility Project, June 1-September 30, 1979," Los Alamos Scientific Laboratory report LA-8237PR (June 1980).

26. D. D. Cobb and J. R. Phillips, "Nondestructive Measurements on Spent Fuel for the Nuclear Fuel Cycle," Nucl. Mater. Manage. IX (Proceedings Isgue), 708-719 (1980).

27. D. D. Cobh, Ed., "Compendium of Monthly Activity Reports: June 1979-December 1980: Spent Fuel Storage Facility Project," Iros Alamos National Laboratory, Safeguards Systems Group internal document (January 1981).

28. M. Conte, M. Muchnino, F. K. Schmitz, "Postirradiation Obgervations of Mixed Oxides with Initinl Addition of Fission product Elements," Nucl. Technol. 16 (October 1972).
29. D. Cublcclott1, J. S, Sanecki, R, V. Strain, S. Greenberg, I. A. Neimark, and C. I. Johnson, "The Nature of Flation-Product Deposits Inside LWR Fuel Rods," Proc. MNS Topical Meeting on water Reacior Fuel Performance, St. Charles, Illinol., May 9-11, 1979; Pp. 282-294.

30. M. B, Cutrone and G. F. Valby, "Gamma Scan Measurements at Quad Cities Nuclear Power Station Unit 1 Following Cycle 2," Electric Power Research Institute report EPRI NP-214 (July 1976).

31. H. H. Davis, T. P. Papazoglou, and L. J. Ferrell, "Poolside Examination of PHR Demonstration Fuel Assemblies and Creep specimensEnd of Cycle," Babcock and Wilcox report LRC 4733-3 (May 1977).

32. K. Debertin and $H$. Ramthun, "Burn-up Determination of Irradiated Fuels: by Means of Their Heat Output," Atomkernenergie 2l, No. 2 , 110-122 (1973).

33. E. J. Dowdy and J. T. Caldwell, Eds., "Irradiated Fuel Monitors. Preliminary Feasibility Study," Los Alamos Scientific Laboram tory report LA-7699 (ISPO-51) (May 1979).

34. E. J. Dowdy, A. A. Robba, R. B. Hastings, and S. W. France, "A New Instrument for the Confirmation of Declared Power Histories of Central station Nuclear Power Plants," Nucl. Mater. Manage. VIII, 689-707 (1979).

35. E. J. Dowdy, N. Nicholson, and J. T. Caldwell, "Irradiated Fuel Monitoring by Cerenkov Glow Intensity Measurements," Los Alamos Scientific Laboratory report LA-7838MS (ISPO-61) (September 1979).

36. E. J. Dowdy, N. Nicholson, and J. T. Caldwell, "A Nonintrusive Irradiated Fuel Inventory Confirmation Technique," Proc. 2nd Annual Symp. on Safequards and Nucl. Mater. Manage., Edinburgh, Scotland, March 1980 (European Safeguards Research and Development Association, 1979), ESARDA 11, pp. 353-358.

37. E. J. Dowdy, N. Nicholeon, and J. T. Caldwell, "Irradiated Fuel Monitoring by Cerenkov Glow Intensity Measuremente," in Measurement Technology for Safeguard and Materials Control, T. R. Canada and B. $S$. Carpenter, Eds., National Bureau of Standards Special Publication 582 (June 1980), Pp. 239-256.

38. T. N. Dragnev, "Experimental Techniques for Measuring Burnup Nondestructive Techniques: Gamma Spectroscopy," International Atomic Energy Agency report IASA/STR-4B (October 1974).

39. T. N. Dragnev, "Bondestructive Assay Tech" niques for Nuclear Safeguards Measurements," In Atomic Energy Review, Vol. 11, No. 2 (1973). 
40. R. W. Durhaw, "Burnup of Ceramic Tuel by Gamm-Ray Scanning," Atomic mergy of Canada Linited report AECL-2688 (Apri1 1967).

41. G. W. Eccleston, H. O. Henlove, and M. W. Echo, "A wasurement for Higin Enrichment Spent Fuel Asnemblies and Waste Sollde," Nucl. Mater. Manage. VIII, 344-355 (1979).

42. G. W. Eccleeton, R. G. Schrandt, J. L. MacDonald, F. H. Cverna, "Honte Carlo Calculational Deaign of an NDA Indtrument for the Aasay of Waste Products from High Inriched Uranive Spent Fuels," in venurement Technology for safeguards and Materiale control, T. R. Cannda and B. 5. Carpenter, Eds.. National Bureau of Standards Special Publication 582 (June 1980), Pp. 472-496.

43. R. R. Edwards, "A Review of Recent Studies of Hondestructive Assay Methods for Irradiated Nuclear Fuel,$"$ Nuclear applications 4 , 245 (April 1968).

44. P. Feỏotov, N. M. Kazarinov, and A. A. Voronkov, "The Use of Neutron Scanning Method for Analysis of Spent VIER Assemblies in Safeguarding Syotems," presented at the IAEA Advisory Group Meeting on Method: and Techniques for NDA Safeguards Heasurements of Power Reactor Spent Fuel, Vienna, October 28November 2, 1979.

45. P. Filss, "Fissile Isotope Determination in Irradiated Fuel Elements and Waste Samples Using Sb-Be Neutrons," Proc. Buropean Nuclear Conference, Paris, April 1975. (IAEA Research Contract 1559/RB "Development of NDA Techniques for the Uranium/Thorium Fuel (ycle").

46. P. Filss, "NDA Techniques for Irradiated Fissile Material in Extended Configurations," in Nuclear Safeguards Technology 1978, Proc. Symp., Vienna, October 2-6, 1978 (International Atomic Energy Agency, Vienna, 1979), IAEA-SM-231/17, Vol. II, pp. 97-111.

47. P. Filss, "Non-destructive Control of Fiazile Material Containing Radiaactive Fiseion Products with a Sb-Be-Neutron Source by Selective Transport of Fission Neutrons in Hydrogeneous Material," Kernfor schungsanlage Julich report Jul-1046-CT (February 1974).

48. R. S. Forsyth and W. H. Blackadder, "Use of the Fission Product Ru-106 Gam Mctivity as a Method for Eatimating the Relative Number of Fission Events in $235 \mathrm{U}$ and $239_{\mathrm{Pu}}$ in Low Enriched Fuel Elemente," in Safeguards Techniques, Proc, Symp., Karlaruhe, July 610, 1970 (International Atomic Energy Agency, vienna, 1970), IAEn-SM-133/4, vol. I, pp. 521-532.

49. N. Fuhrman, V. Pasupathi, and L. V. Consetti, "PCI Observation in a Combustion lngineering PWR," Proc. ANS Topical Heeting on Water Reactor vuel Performance, st. Charles, Illinois, May 9-11, 1979, PP. 262-272.
50. V. Ya. Gabeskiriya, et al.. "Content of Uranium Isotopes and Transuranium Elements in the Spent Ful of a VWER-365 Reactor," Atomnaya Energlya, Vol, 44, No. 5, 446 (Hay 1978).

51. R. Gold, F. H. Ruddy, E. P. Lippineott, W. N. McElroy, and J. H. Roberts, "Spent Thermal Reactor Fuel Aasembly Characterization with Solid State Track Recordern," Hanford Engineering Development Laboratory report HEDLTHE 78-89 UC-796.

52. T. Gozan1, "Active Direct Measurement of Residual Fisolle Content in spent Fuel Assemblies," slectric Power Research Institute report EPRI 278-1 (July 1975).

53. T. Gozani, Mondestructive Aseay of Spent Fuel for Determination of Residual Firaile Content," Nucl. Mater. Manage. $\underline{v}$ 514-524 (1976).

54. H. Graber, A. Keddar, G. Hotmann, and $s$. Negel, "Ganma Spectrometric Determination of Burnup and Cooling Time of Irradiateo $\mathrm{ECH}-1$ Fuel Assemblies," in Nuclear Safeguards Techrology 1978, Proc. Symp., Vienna, October 26, 1978 (International Atomic Energy Agency, Vienna, 2979), IAEA-SM-231/129, Vol. I, pp. 353-368.

55. H. Graber, G. Hofmann, and H. C. Mehner, "Some Remarks to Correlation Techniques Uged for NDA Safeguards Meawurements," presented at the IAEA Advigory Group Meeting on Methods and Techniques for NDA Safeguards Measurements of Power Reactor spent Fuel, vienna, October 28-November 2, 1979.

56. L. Green, J. T Kriege, and M. Natelson, "The Reactivity Perturbation Assay of Irradiated Fuel Rods," Nucl. Technol. 32, 186-204 (1977).

57. M. Paoletti Gualandi, P. Peroni, M. Bresenti, M. Cuypers, D. D'Adamo, and L. Lezzoli, "Determination of Burnup and Plutontum Content in Irradiated Fuels by Gama-Spectrometry Measurement: of Radioactive Fission Products, Safeguarding Nuclear Materials, Proc. Symp., Vienna, October 20 24, 1975 (International Atomic Energy Agency, Vienna, 1976), IAEA-SH-201/3, Vol. II, PP. 613-624.

5a. 5. Guardini and G. Guzzi, Neutron Emission for Spent Fuels of Preasurized and Bolling Water Reactors by Spontaneous Fissions and $(\alpha, n)$. Reactions," Euratom report EUR 6315en (1979).

59. s. Guardini and G. Guzzl, "Pont-Irradiation Analyais of High Burnup Light Water Reactor Fuel Elemente," presented at the 3rd ASTy BuRATOA Symp., October 1-5, 1979.

60. T. Haginoya, M. Ferraris, W. Frenzel, I. Kles, F. Klik, v. Poroykov, L. Thorne, and s. Thoritensen, "Experience in the Application of Agency Inopection Practices," in 
Nuclear Sinequarda Technology 1978, Proc. Symp.. Vienna, October 2-6, 1978 (International Atomic Energy Agancy, Vienna, 1979), IAEA-SM-231/105, Vol. I, pp. 3-9.

61. G. L. Hanna, "Gamma-Ray Measurement of Spent IIFAR Juel Elements for Safeguards verification, Part I: Experinental Evaluation of Method, and Part II: Theoretical Evi'uation of Method," Autralian Safeguards office reports $\mathrm{A50/R2}$ and $\mathrm{A50/R3}$ :(July 1978).

62. R. J. S. f. trry, J. K. Maldijk, and J, P. Braak, "Ganma Spectrometric Determination of Isotopic Composition Without Une of Standards," In Nuclear Safeguards Technology 1978 , Proc. Symp., vienna, October 20-24, 2975 (International Atomic Energy Agency, Vienna, 1976), IAXA-SM-201/66, Vol. II, Pp. 235-246.

63. C. R. Hatcher, "Errors In Spent Fuel Cooling Tine Determination Due to Constant Power approximation of Irradiation Hiatory, "International Atomic Energy Agency internal report (October 1979).

64. R. L. Heath, "The Potential of High-Resolution Gamma-Ray Spectronetry for the Assay of Irradiated Reactor Fuel," in Safeguards Res. Devel., Proc. Symp., Arganne National Laboratory, June 26, 1967, report HASH-1076, pp. 115-129 (1967).

65. H. Hick and H. Lamer, "Interpretation of Garma Spectrometric Measurements on Burnt Fuel Elementw," in Safequards Techniques, Proc. Symp.. Karleruhe, July 6-10, 1970 (International atomic Energy Agency, Vienna, 1970). IAEA-SH-133/5, Vol. I, PP. 533-537.

66. S. Hiller, "Gama-Spectronetric Burnup Determination in Reactor Fuels Rods," Kerntechnik 12. Ho. 11, 485-490 (1970).

67. S. T. Haue, C. R. Hatcher, and $K$. Kaieda, "Cooling Time Determination of spent Ruel," Nucl. Mater. Manage. VIII, 356-367 (1979).

68. S. T. Hsue, T. W. Crane, W. L. Talbert, Jr., and $J$. C. Iee, "Nondestructive Assay Mothod" for Irradiated Nuclear Fuels," Los Alanos Scientific Laboratory report LA-6923 (January 1978 ).

69. S. T. Houe, J. E. Stewart, K. Raieda, J. K. Halbig, J. R. Phillips, D. M. Lee, and C. R. Hatcher, "Paseive Neutron Masay of Irradiated Nuclear Fuela," Los dlamo Ecientific Laboratory report LA-7545-is (ISPO-43) (Fobruary 1979).

70. H. Isuruta, T. Suzaki, and S. Matsuura, "Profiles of Activity Ratios of Pission Products Cesiun-134, Cesium-137, and Ruthenium-106 in Low-Enilched $\mathrm{PuO}_{2}-\mathrm{UO}_{2}$ ruel Ansemblies," $\mathrm{J}$. Mucl. Sci. and Technol. $14(1), 43-53$ (January 1977).
71. H. Isuruta, T. Suzaki, and S. Matsuura, "Determination of Pu Accumulated in Irradiated Fuels by Nondentructive Isotopic Correlation Technique," Japan Atomic Energy Reactor Institute memo JAERI-M (1977).

72. P. J. Kreyger, R. J. S Harry, and H. Krockel, "Nondestructive Burn-up Determination by 145 keV Gama-Ray Absorption," in Safeguards Techniques, Proc. Symp., Karlsruhe, July 610, 1970 (International Atomic Energy Agency, Vienna, 1970), IAEA-SM-133/6, Vol. $T$, PP. 545-550.

73. H. Krinninger, S. Wiesner, and c. Faber, "Pulsed Neutron Method for Non-destructive and simultaneous Determination of the $235 \mathrm{U}$ and ${ }^{239} \mathrm{Pu}$ Contents of Irradiated and NonIrradiated Reactor Fuel Elementa," Nucl. Instrum. Methode 73, 13-33 (1969).

74. V. Kupryashkin, T. Haginoya, V. Poroykov, T. Dragnev, and B. Damjanov, "Gamma Spectrometric Measurements of Pressurized Water Reactor Spent Fuel," in Measurement Technology for Safequard, and Haterials Conirol. T. R. Canadà aná B. $\bar{s}$. Carpenter, Bds.. National Bureau of Standards Special Publication 582 (June 1980), Pp. 509-516.

75. L. N. Lazarev, "Nondestructive Methods of Analysis of the Nuclear Fuel of Fast Neutron Reactors," in LMFBR Fuel Reprocessing, Proc. Symp., Leningrad, May 17-21, 1976 (International Atomic Energy Agency, Vienna, 1976), us Energy Research and Development Administration report ERDA-TR-205.

76. D. M. Lee, J. R. Phillips, S. T. Hsue, K. Kaleda, J. K. Halbig, E. G. Medira, and C. R. Hatcher, "A New Approach to the Examination of LWR Irradiated Fuel Assemblies Using Simple Gas Chamber Techriques," Log Alamos Scientific Laboratory report LA-7655-MS (ISPO-48) (March 1979).

77. D. H. Lee, J. R. Phillips, S. T. Heue, K. Kaieda, J. K. Halbig, E. G. Medina, and $C$. R. Hatcher, "h Quick and Accurate Profile Monitor for Irradiated Fuel," Proc. lat Annual Symo. on Safeguards and Nucl. Mater. Manage., Brussels, Belgium, April 25-27, 1979 (Buropean Safeguards Research and Developent Astociation, 1979), ESARDA 10, pp. 265-269.

78. D. M. Lee, "Use of Sealed Tube Neutros Generators for Verification of IWR Fuel Asenblles," Io. Alamos Scientific Imboratory report LA-7996-MS (ISPO-76) (September 1979).

79. D. H. Lee, J. R. Phillips, J. K. Halbig, S. T. Have, L. O. Ifndquitet, E. M. Oxtega, J. c. Calne, J. Swaneen, K. Kaieda, and $\mathbf{E}$. Dermendjiev, "Now Development. In Nondestructive Measurenent and Verlfication of the Irradiated LAR Tue 1,3," in Messurement Technology for Safeguarde ane hateriale control, T. R. Canadi and B. S. carpenter, Is., National Burean of Standarde Special Publicution 582 (June 1980), PP. 426-446. 
Bo. D. H. Lee, J. R. Phillipt, S. T. Haue, $K$. Kaleda, J. K. Halbig, E. G. Madina, and $C$. $R$. Hatcher, "The Examination of LWR Irxadiated ruel Asaemblien Using Simple Ion Chamber Techniques," Nucl. Inst. Methode 176(3), 583 (Octobur 1980).

81. D. M. Lee, "Assay and Verification of Freah and Spent Fuel," Proceedings of the Nuclear Nonproliferation Act Course, Santa Fe, New Mexico, 1980.

82. L. Leenders, "Contribution to the Investigation of Isotopic Correlations Among Nondestructive Measurements on Fuel Rods," Contributions to the Jolnt Safeguards Experiment Mol IV at the Eurochemic Reprocessing Plant, Mol, Belgium, report BLG-486 (September 1973).

83. Y. Matsuda, T. Tamura, and T. Murato, "Nondestructive Active Assay of Uranium-235 and Plutonium-239 in Nuclear Reactor Fuel," in Nuclear Safeguards Technology 1978, Proc. Symp., vienna, October 2-6, 1978 (International Atomic Energy Agency, Vienna, 1979\}, IAFA-SM-231/30, Vol. II, pp. 113-124.

84. S. Matsuura, et al., "Nondestructive GammaRay Spectrometry on Spent Fuels of a Boiling water Reactor," J. of Sci. Technol. 12 (1), 24-34 (January 1975).

85. H. G. Mehner, Mestimung der relative Effektivitaet in Gamma-spektrometrischen Abbrandmesseinrichtungen," Kernenergle $i \geqslant(1)$, 3-5 (1976).

86. C. E. Moss, K. V. N1xon, and W. Bernard, "Scintillator Spent Fuel Monitor," Nucl. Mater. Manage. IX (Proceedings Issue), 214$223(1980)$.

87. C. E. Mo:3s and D. M. Lee, "Gross Gamma-Ray Measurements of Light Water Reactor SpentFuel Assemblies in Underwater Storage Arrays," Los Alamos Scientific Laboratory report LA-8447 (ISPO-132) (December 1980).

88. K. Nakajlma, T. Koizumi, T. Yamanouchi, S. Watanake, and N. Suyama, "Development asd Demonstration of Safeguards Techniques in the Tokal Fuel Reprocessing Plant," in Nuclear Safeguarde Technology 1978, Proc. Symp., Vienna, October 2-6, 1978 (International Atomic Energy Agency, Vienna, 1979), IAEX-SH-231/34, Vol. II, pp. 701-732.

89. H, Natsume, S. Matsuura, H. Okashita, H. Unezawa, and H. Ezure, "Gamma-Ray Spectrometry and Chemical Analysis on JPDR-1 Spent Fuels," Japan Atomic Energy Research Institute report JAERI-meno-6921 (October 1975).

90. M. P. Navalkar, K. Chandramoleshwar, and D. v. S. Ramakrishna, "A. Feasibility Study of Nondestructive Assay of $\mathrm{Pu}-239$ and $\mathrm{U}-235$ in Irradiated Samples Using Slowing Down Time Lead Spectrometer," Nucleonik 1I, No. 1, $54-56$ (1968).
91. N. Nicholson, "Javelin Model 22 Night Vision Device Spent Fuel Vlewing Procedures Manual," (Q-2/79-788, ISPO-78), IOS Alamos Scientific Inboratory document '(October 1979).

92. N. Nicholson and E. J. Dowdy, "Irradiated Fuel Examination Using the Cerenkov Technique," Los Alamos Scientific Laboratory report LA-8767-MS (March 1981).

93. A. Ohno and 5. Matsuura, Measurement of the Gamma Dose-Rate Distribution in a Spent Fuel Assembly with a Thermoluminescent Detector," Nucl. Technol. 47, 485 (March 1980).

94. E. H. Ottewitte, "Evaluation of Analytical Capabilities for Accurate Prediction of Isotopic Correlation Ratios," Idaho National Engineering Laboratory report RE-P-77-044 (June 1977).

95. G. R. Parkos and G. F. Valby, "Gamma Scan Measurements at zion Station Unit 2 Following Cycle 1," Electric Power Research Institute report EPRI NP-509 (October 1977).

96. J. R. Phlllips, "New Techniques in Preciston Gamma Scanning: Application to Fast-Breeder Reactor Fuel Pins," Los Alamos National Laboratory report LA-5260-T (July 1973).

97. J. R. Phillips, G. R. Waterbury, N. W. Vanderborgh, "Distribution of ${ }^{134} \mathrm{Cs}$ and ${ }^{137} \mathrm{Cs}$ in the Axial $\mathrm{UO}_{2}$ Blankets of Irradiated (U, $\mathrm{Pu})_{2}$ Fuel Pins," J. Inorg. Nucl. Chem., Vol. 36, 17-23 (1974).

98. J. R. Phillips, J. R. Netuschil, J. N. Quintana, and $G$. R. Waterbury, "Axial Distribution of ${ }^{95} \mathrm{Nb}$ and $95 \mathrm{Zr}$ Isotopes in Irradiated $\mathrm{UO}_{2}-\mathrm{PuO}_{2}$ Fuel Pins," $\mathrm{J}$. Inorg. Nucl. Chem., Vol. 37, 1337-1340 (1975).

99. J. R. Phillips, G. R. Waterbury, N. E. Vanderborgh, and T. K. Marshall, "Quantitative Determination of Fission Products in Irradiated Fuel PIns Using Nondestructive Gamma Scanning," Anal. Chem. 47, 71-75 (1975).

100. J. R. Phillips, S. T. Hsue, K. Kaieda, D. M. Lee, J. K. Halbig, E. G. Medina, C. R. Hatcher, and T. R. Bement, "Nondestructive Determination of Burnup and cooling Times of Irradiated Fuel Assemblies," Proc. Ist Annual Symp. On Safeguards and Nucl. Mater. Manage..' Brussels, Belgium, April 25-27, 1979 (European Safeguards Research and Development Association, 1979), ESARDA 10, pp. 270-276.

101. J. R. Phillips, D. M. Lee, T. R. Bement, J. K. Halbig, S. T. Hsue, and K. Kaieda, "Nondestructive Examination of Irradiated LWR Fuel Assemblies," Nucl. Mater. Manage. VIII, 451-467 (1979).

102. J. R. Phillips, T. R. Bement, K. Kaleda, and E. G. Medina, "Nondestructive Verification of Relative Burnup values and Cooling Times 
of Irradiated MTR Fuel Elements," Los Mlamos Scientific Laboratory report LA-7949-MS (August 1979).

103. J. R. Phtllips, G. E. Bosler, J. K, Halblg, and D. M. Lee, "Nondestructive Measurement of Spent Fuel Assemblies at the Toka1 Reprocessing and storage Facility," Los Alamos Sctentific Laboratory report LA-8076-MS (ISPO-44) (Decembex 1979),

104. J. R. Phillips, J. K. Halbig, D. M. Lee, 5. E. Beach, T. R. Bement, E. Dermendjlev, C.

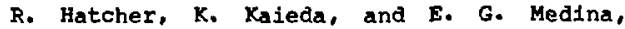
"Application of Nondestructive Gamma-Ray and Neutron Techniques for the Safeguarding of Irradiated Fuel Materials," Ios Alamos Scientific Laboratory report IA-8212 (ISPO-77) (May 1980).

105. J. R. Phillips, J. E. Foley, H. O. Menlove, and $T$. D. Reilly, "Instrumentation Avaflable to IAEA Inspectors," in "Materials Management in an Internationally Safeguarded Fuels Reprocessing Plant," Los Alamos Scientific Lahoratory report LA-8042 (April 1980), Vol. III, App. N.

106. J. R. Phillips, G. E. Bosler, and J. K. halbig, "Nondestructive Measurements of Irradiated Fuel Assemblies at a Reprocessing Facilfty," Trans. ANS 34, 159 (1980).

107. H. G. Priesmeyer and M. Harz, "Isotopic Assay in Irradiated Fuel by Neutron Resonance Analysis," in Safeguaraing Nuclear Materials, Proc. Symp., Vienna, October 20-24, 1975 (International Atomic Energy Agency, Vienna, 1976), IAEA-SM-201/4, Vol. II, pp. 625-632.

108. G. L. Ragan, R. S. Booth, T. J. Burns, J. D. Jenkins, C. R. Weisbin, and L. R. Williams, "System for Assay of Fissile Content of Spent LMFBR Fuel Subassemblies," Trans. ANS 23, $95-96$ ( 1976$)$.

109. G. L. Ragan, M. M. Chiles, C. W. Ricker, D. T. Ingersoll, and G. G. Slaughter, "Nondestructive Assay of Subassemblies of Various Spent or Fresh Fuels by Active Neutron Interrogation," Nucl. Mater. Manage. VIII, 334-343 (1979).

110. G. L. Ragan, C. W. Ricker, M. M. Chiles, D. T. Ingersoll, G. G. Slaughter, and L. R. Williams, "System for Nondestructive Assay of spent fuel Subassemblies--Comparison of Calculations and Measurements," in Measurement Technology for Safeguards and Materials Control, T. R. Canada and B. S. Carpenter, Eds.. National Bureau of Standards Special Publication 582 (June 1980), pp. 447-456.

1.1. H. Ramthun and K. Debertin, "Burn-up Determination of Irradiated Fuels by Means of Their Heat Output," Atomkernenergie 19, No. $1,17-22(1972)$.
112. N. C. Rasmussen, J. A, Soyka, and $5 . \lambda$. Mayman, "The Nondestructive Measurement of Burn-up by Gama-Ray "spectroscopy," in Nuclear Materials Management, Proc. Symp., Vienna, Auquat 30-Septerber 3, 1965 (International Atomic Energy Agency, Vienna, 1966), IAEA-SM-67/45, pp. 829-849.

113. J. E. Rein, "Status of Burnup Measurement Methodology," in Anal. Meth. in the Nucl. Fuel Cycle, Proc. Symp., Vienna, November 29December 3, 1971 (International Atomic Energy Agency, Vienna, 1972), SM-149/40, pp. 449472.

114. P. M. Rinard, "Gamma Doses From Irradiated Assemblies Under Water," Los Alamos scientific Laboratory report IA-7914-MS (July 1979).

115. P. M. Rinard, "Irradiated Fuel Inspection in a Storage Pond with No Fuel Novement and an Uncollimated Detector," Los Alamos Scientific Laboratory report LA-8463-MS (ISPO-110) (July 1980).

116. W. Rotter, "Determination of Burn-up of Irradiated Fuel Elements by Pulsed Neutron Interrogation," Ann. Nucl. Sci. Eng. 1, 451458 (1974).

117. G. Schulze, H. Wirz, I. Koeh, and R. Wellum, "Neutron Assay Plus Isotopic Correlations: A Method for Determining $P u$ and Burnup in Spent LWR Fuel Assemblies," Proc. 2nd Annual Symp. on Safeguards and Nucl. Mater. Manage..' Edinburgh, Scotland, March 1980 (European Safeguards Research and Development Association, 1979), ESARDA 11, pp. 396-403.

118. M. Sultan, A. El-Kady, and N. Ashoub, "An Activity Ratio Method for Experimental Evaluation of Exposure of Irradiated Nuclear Fuels by Gamma Spectroscopy," Proc. 2nd Annual Symp. on Safeguards and Nucl. Mater. Manaye... Edinburgh, Scotland, March 1980 (European Safeguards Research and Development Association, 1979), ESARDA 11, pp. 115-118.

119. T. Suzaki, H. Tsuruta, and S. Matsuura, "NonDestructive Gamma-Ray Spectrometry and Analysis on Spent Fuel Assemblies of the JPDR-1 Core," Japan Atomic Energy Research Institute report JAERI Hemo 8164 (March 1979).

120. K. Takeda, K. Yokoyama, T. Kouzerm1, H. Iwanaga, I. Kobayashi, S. Matsuura, $H$. Tsuruta, T. Suzaki, and A. Ohno, "Collection and Analysis of Gamma Spectra of Irradiated Fuel Assemblies," Power Reactor and Neutron Fuel Development Corporation (Japan) report TASTEX Task-B (February 1981).

121. C. C. Thomas, Jx, D. D. Cobb, and C. A. Ostenak, "Spent-Fuel Composition: A ComparIson of Predicted and Measured Data," Los Alamos National Laboratory report LA-8764-MS (Harch 1981). 
122. S. Taujimura, "Applicability of Nondestructive Amsay Techniquen to spent Fuel. from BNR," in Nuclear Safeguerde Technology 1978, Froc. Symp., Vienna, October 2-6, 1978 (International Atomic Energy Agency, Vienna, 1979 ), IAEA-SN-231/29, Vol. I. Pp. 305-316.

123. H. Tsuruta, T. Suzak1, and S. Matsuura, "Profiles of Activity Ratios of Fission Products, Cerium-134, Cesium-137, and Ruthenium-106 in Iow-Erriched $\mathrm{PuO}_{2}-\mathrm{UO}_{2}$ Fuel Assemblies," J. Nucl. Scl. Technol. 14(1), 43-53 (January 1977).

124. C. K. Tzou and C. M. Yang, "Nondestructive Burnup Determination by Gamma-Ray Spectroscopy," Nucl. Technol. 24, 246-251 (1974).

125. H. Umezaua, et. al., "Correlation of Amounts of Trassplutonium Nuclides with Burnup in the JPDR-1 Spent Fuel," J. Nucl. Sci. Technol. 10(B), 489-492 (August 1973).
126. J. Valovic, v, Petenyi, S. B. Rana, D. Mikusova, and $J$. Kmonena, "The Application of Gamma and Isotopic Correlation Techniques for Safeguards Identification and Verification Purposen," IAEA research contract 1443 , Bohunice Nuclear Power Plant, Bohunice, Czechoulovakia (1975).

127. A. A. Voronkov, B. J. Galkin, N. M. Kazarinov, and P. I. Fedotov, "The Use of Passive and Induced Fission Neutron Emission for NDA of WVER Type of Spent Fuel," in Nuclear Safeguards Technology 1978, Proc. Symp., Vienna, October 2-6, 1978 (International Atomic Energy Agency, Vienna, 1979), IAEA-SM-231/36, Vol. I, PP. 395-406.

128. C. R. Weisbin, R. H. Augustson, J. S. Hendricks, A. E. Evans, and G. D. Turner, "Nondestructive Assay of Power Reactor Fuel Assemblies," Nucl. Technol. 15, 455-461 (1972). 


\section{APPENDIX D}

IRRADI ATED-FUEL CALCULATIONS

G. E. Bosler and J. R. Rhillips

Safeguards Assay Group Q-1

I. ISOTOPE PRODUCTION AND DEPLETION

Neutron and photon characteristics inherent to irradiated fuel assemblies depend on the production and depletion of various tranguranic and fission-product isotopes. Measurement of these charanteristics to verify irradiated fuel parameters, such as exposure, cooling time, and fissile content, requires knowledge of the correlation between the measured signal and the parameter being evaluated. Correlations either independent of irradiated fuel conditions or only dependent on initial, well-known parameters, such as ${ }^{235} \mathrm{U}$ enrichment, are desirable. In an effort to better understand important correlations and to examine their possible dependence on irradiated fuel parameters, a calculational study was performed for fuel from the $H$. $B$. Robinson Unit 2 reactor. This fuel has been analyzed destructively to determine furnup, exposure, transuranic isotopic composition, and fission-product isotopic composition. Calculations to determine the same information were performed using the EPRI-CELL ${ }^{1}$ and EPRI-CINDER ${ }^{2,3}$ codes with a detailed power history for the $H . B$. Robinson fuel. Comparisons of the calculated and measured data are shown in Table D-I for two H. B. Robinson samples. Nost of the comparisons are reasonably good, except for ${ }^{234} \mathrm{U},{ }^{238} \mathrm{Pu}$, and ${ }^{242} \mathrm{Pu}$. Larger relative differences for these isotopes are not unexpected because the quantity of ${ }^{234} \mathrm{U}$ is very small, the presence of ${ }^{238} \mathrm{v}$ interferes with mass spectrometry measurements of ${ }^{238} \mathrm{Pu}$, and calculations of the higher actinide isotopes, such as ${ }^{242} \mathrm{Pu}$, are more uncertain.

Results in Table D-I indicate that the calculational methodology can be used to investigate the effects of changes in basic operating parameters on isotope production and depletion. For further investigations, a base case using the $H$. B. Fohinson model was established with an inftial ${ }^{235} \mathrm{U}$ enrichment of 2.5618 , a $\mathrm{UO}_{2}$ mass density of 90.8148 of theoretical density, and a constant power level of $200 \mathrm{w} / \mathrm{cm}$. Irradiation times were calculated for burnups up to $50 \mathrm{Gwd} / \mathrm{tU}$. To examine parameter sensitivities, one of the base-case parameters was varied, whereas the other parameters were fixed. Parameter variations included

(1) initlal ${ }^{235} \mathrm{v}$ enrichments of 2.0-4.58;

(2) $\mathrm{UO}_{2}$ mass densities of 90.814 and 948 of theoretical density:

(3) power levels of 160,200 , and $240 \mathrm{w} / \mathrm{cm}$; and

(4) irradiation histories with various combinations of 1-yr full power cycles (U) and 1-yr shutdown periods (D).

The principal chains for production and depletion of transurantc isotopes are shown in Fig. D-1. In this figure, horizontal transitions, for example ${ }^{239} \mathrm{Pu}$ to ${ }^{240} \mathrm{Pu}$, indicate a neutron capture event. Except for the ${ }^{242} \mathrm{Am}$ to ${ }^{242} \mathrm{Pu}$ transition, vertical transizions result from beta decay. For the ${ }^{242} \mathrm{Am}$ to ${ }^{242} \mathrm{Pu}$ transition, the ${ }^{242} \mathrm{Am}$ undergoes an electron capture. Other nuclear events creating chains different from those shown in Flg. D-1 occur. However, most of these events are secondary, producing negligible anount: of material compared to the principal events shown in Eig. $0-1$.

Table D-II shows that, of the isotopes shown in Fig. D-1, ${ }^{235} \mathrm{U},{ }^{241} \mathrm{Mm},{ }^{242} \mathrm{Cm},{ }^{244} \mathrm{~cm}$, and most of the plutoniu 1uotopes are of primary interest because they are the 1mportant sources of neutrons In Irradiated fuels. Interpretation of passive neutron agnale from irradiated fuel asseablies requires knowledge of the production of these neutron-entting isotopes. 
TABLE D-I

COMPARISON OF MEASURED AND CALCULATED

H. B. ROBINSON-2 ISOTOPIC RATIOS

\begin{tabular}{|c|c|c|c|c|c|c|}
\hline \multirow{2}{*}{ Quantity } & \multicolumn{3}{|c|}{ Sample PBA } & \multicolumn{3}{|c|}{ Sample PBB } \\
\hline & $\begin{array}{l}\text { Mensured } \\
\text { Value }\end{array}$ & $\begin{array}{c}\text { Calculated } \\
\text { Value }\end{array}$ & $\begin{array}{l}\text { Difference } \\
\text { (v) }\end{array}$ & $\begin{array}{l}\text { Measured } \\
\text { value }\end{array}$ & $\begin{array}{l}\text { Calculated } \\
\text { value }\end{array}$ & $\begin{array}{c}\text { Difference } \\
\text { (v) }\end{array}$ \\
\hline Burnup, at.s & 2.559 & 2.560 & +0.04 & 3.221 & 3.221 & 0.00 \\
\hline Exposure, Gwd/tU & 24.57 & 24.66 & +0.37 & 30.92 & 31.19 & +0.89 \\
\hline${ }^{234} \mathrm{U} / \mathrm{U}$ & 0.00016 & 0.00014 & -14.04 & 0.00014 & 0.00012 & -12.81 \\
\hline $235 \mathrm{U} / \mathrm{U}$ & 0.00816 & 0.00928 & +1.53 & 0.00612 & 0.00588 & -3.84 \\
\hline $236 \mathrm{U} / \mathrm{u}$ & 0.00326 & 0.00322 & -1.08 & 0.00353 & 0.00357 & +1.52 \\
\hline $238 \mathrm{v} / \mathrm{v}$ & 0.98842 & 0.98835 & -0.01 & 0.99022 & 0.99043 & +0.02 \\
\hline${ }^{238_{\mathrm{Pu}} / \mathrm{Pu}}$ & 0.01143 & 0.00979 & $-14 \cdot 35$ & 0.01676 & 0.01452 & $-13 \cdot 35$ \\
\hline${ }^{239} \mathrm{Pu} / \mathrm{Pu}$ & 0.59557 & 0.59365 & -0.32 & 0.54261 & 0.53966 & -0.54 \\
\hline $240_{\mathrm{Pu} / \mathrm{Pu}}$ & 0.23290 & 0.22766 & -2.25 & 0.25101 & 0.24002 & $-4 \cdot 38$ \\
\hline $241_{\mathrm{Pu} / \mathrm{Pu}}$ & 0.11842 & 0.12385 & +4.58 & 0.12998 & 0.13772 & +5.95 \\
\hline $242 \mathrm{Pu} / \mathrm{Pu}$ & 0.04168 & 0.04506 & +8.10 & 0.05964 & 0.06807 & +11.41 \\
\hline $239_{\mathrm{Pu}} / 238_{\mathrm{v}}$ & 0.00494 & 0.00486 & -1.61 & 0.00518 & 0.00496 & -4.28 \\
\hline $148_{\mathrm{Nd} / 238_{\mathrm{U}}}$ & 0.00045 & 0.00047 & +3.74 & 0.00057 & 0.00059 & +3.96 \\
\hline
\end{tabular}

aleasured isotopic ratios reported in Ref. 4, p. 16. Calculated values from $3 / 81$ tandem CELL/CINDER-2 calculations using a detailed power history and 506.75-day cooling.

TABLE D-II

SOURCES OF NEUTRONS IN IRRADIATED UO 2 MATERIALS

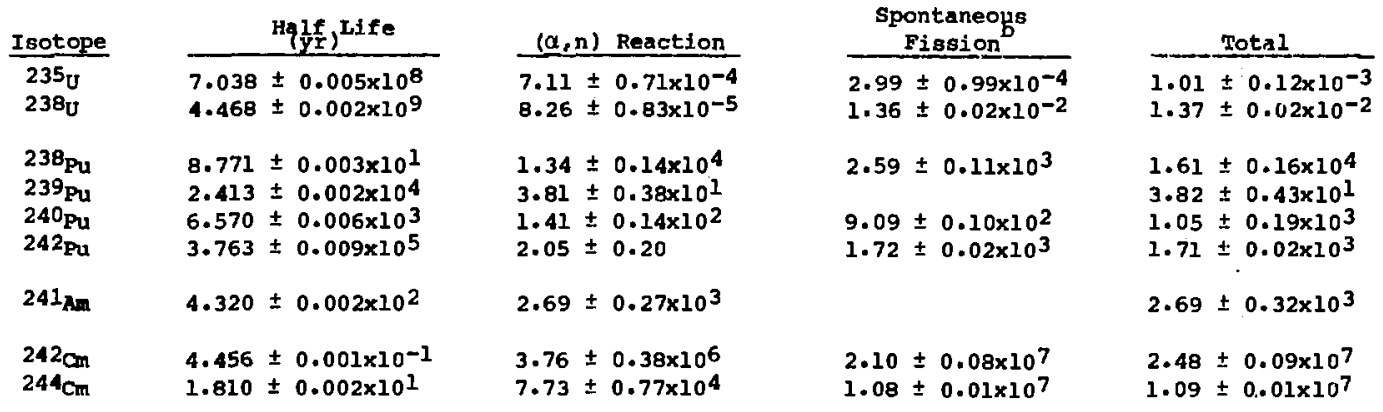

aspecific neutron emission rates in neutrons per gram-second.

bThe reference value for spontaneous fisston 18

$\bar{v}_{\text {sp }}=3.756$ for ${ }^{252} \mathrm{cf}$ 


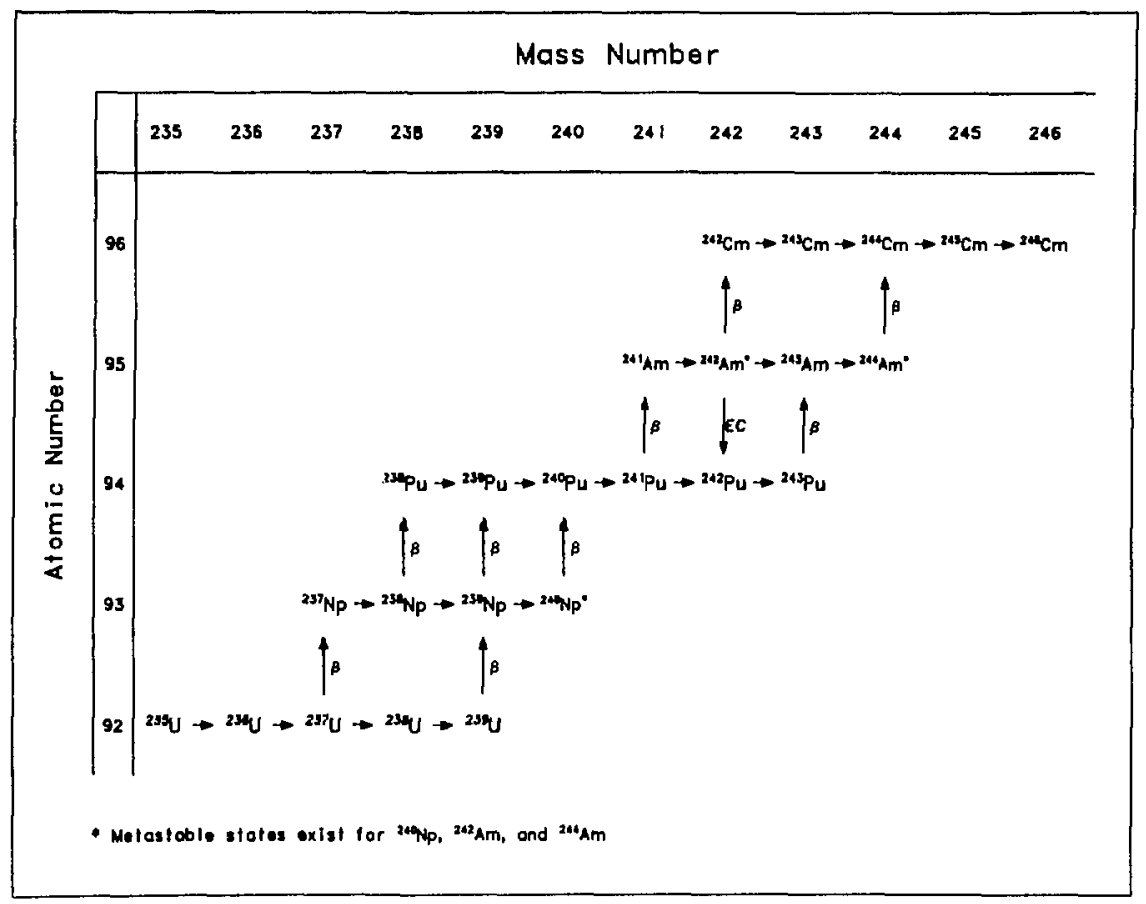

Fig. D-1. Light-water reactor production chains for the transuranic isotopes from $235 \mathrm{U}$ and $238 \mathrm{U}$ feed material.

The fissile isotopes of urantum and plutonium are shown in Figs. D-2 through $D-5$. In Fig. D-2, the ${ }^{235} \mathrm{U}$ concentration is shown. Concentration of this isotope depends primaxily on the initial enrichment. Other parameters examined have very little effect. Plutonium-239, shown in Fig. D-3, is affected by initial ${ }^{235} \mathrm{U}$ enrichment and $\mathrm{VO}_{2}$ mass density, but is relatively unaffected by power level and irradiation history. Similarly, ${ }^{241} \mathrm{Pu}$, shown in Fig. D 4 , is affected by initial enrichment and $\mathrm{UO}_{2}$ density. Power levels have little effect on the production of ${ }^{241} \mathrm{Pu}$. Recause of the relatively short half-life for ${ }^{241} \mathrm{Pu} 114.7$ $\mathrm{yr}$ ), Iong shutdown periods affect the ${ }^{241} \mathrm{Pu}$ concentration. This is shown in the final plot of Fig. D-4. Figure D-5 shows that total fissile content $\left({ }^{235} \mathrm{v}+{ }^{239} \mathrm{Pu}+{ }^{241} \mathrm{pu}\right)$ is affected primari $3 \mathrm{y}$ by initial enrichment.

The principal neutron-producing plutonium isotopes $\left({ }^{238} \mathrm{Pu},{ }^{240} \mathrm{Pu}\right.$, and $\left.{ }^{242} \mathrm{Pu}\right)$ are shown in Figs. D-6 through D-8. Anericium-241, which results from the decay of ${ }^{241} \mathrm{Pu}$, is shown in Fig. Dr.9. All of these isotopes have some sensitivity to initial ${ }^{235} \mathrm{U}$ enrichment. For isotopes with short halflives or for those formed from other isotopes with short half-lives, there is also some dependence on irradiation history.

The curium isotopes ${ }^{242} \mathrm{~cm}$ and ${ }^{244} \mathrm{~cm}$ are shown in Figs. D-10 and D-11. Curfum-242 is very sensitive to all parameters, whereas ${ }^{244} \mathrm{Cm}$ is basically sensitive only to initial ${ }^{235} \mathrm{U}$ enrichment. Because of the short half-life for ${ }^{242} \mathrm{~cm}$ $\left(t_{1 / 2}=163\right.$ days $)$, much of this isotope decays away during extended shutiowns ox after discharge.

\section{NEUTRON SIGNALS}

production and depletion data for transuranic isotopes described in the previous section have been used to obtain relative neutron source strengths as a function of exposure and cooling time. The neutron source terus reiate only to the production of neutrons within the fuel material from spontaneous fissloning and $(x, n)$ reactions 

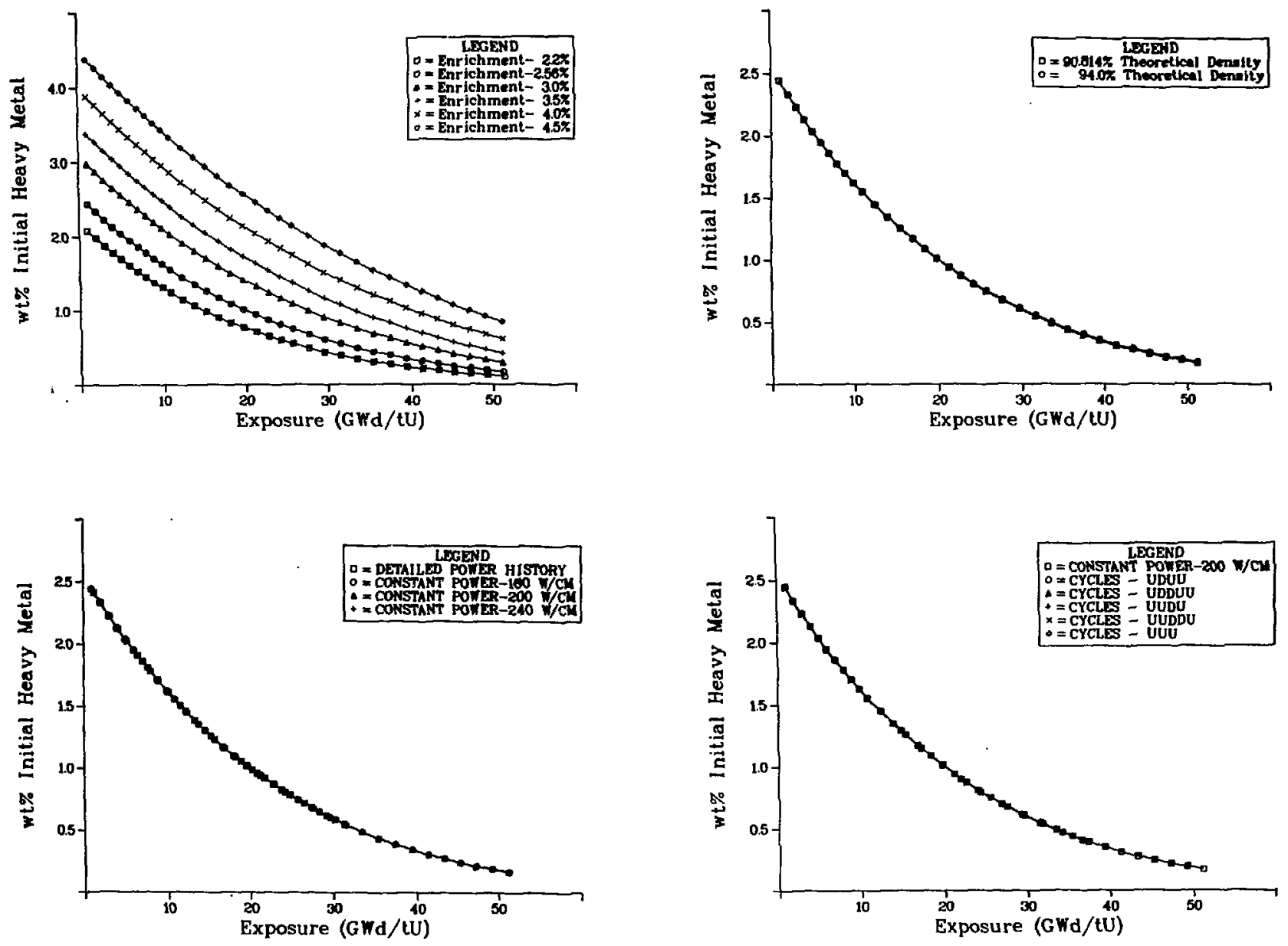

Fig. D-2.

Sengitivity of $235 \mathrm{v}$ to various reactor parameters as a function of exposure. 

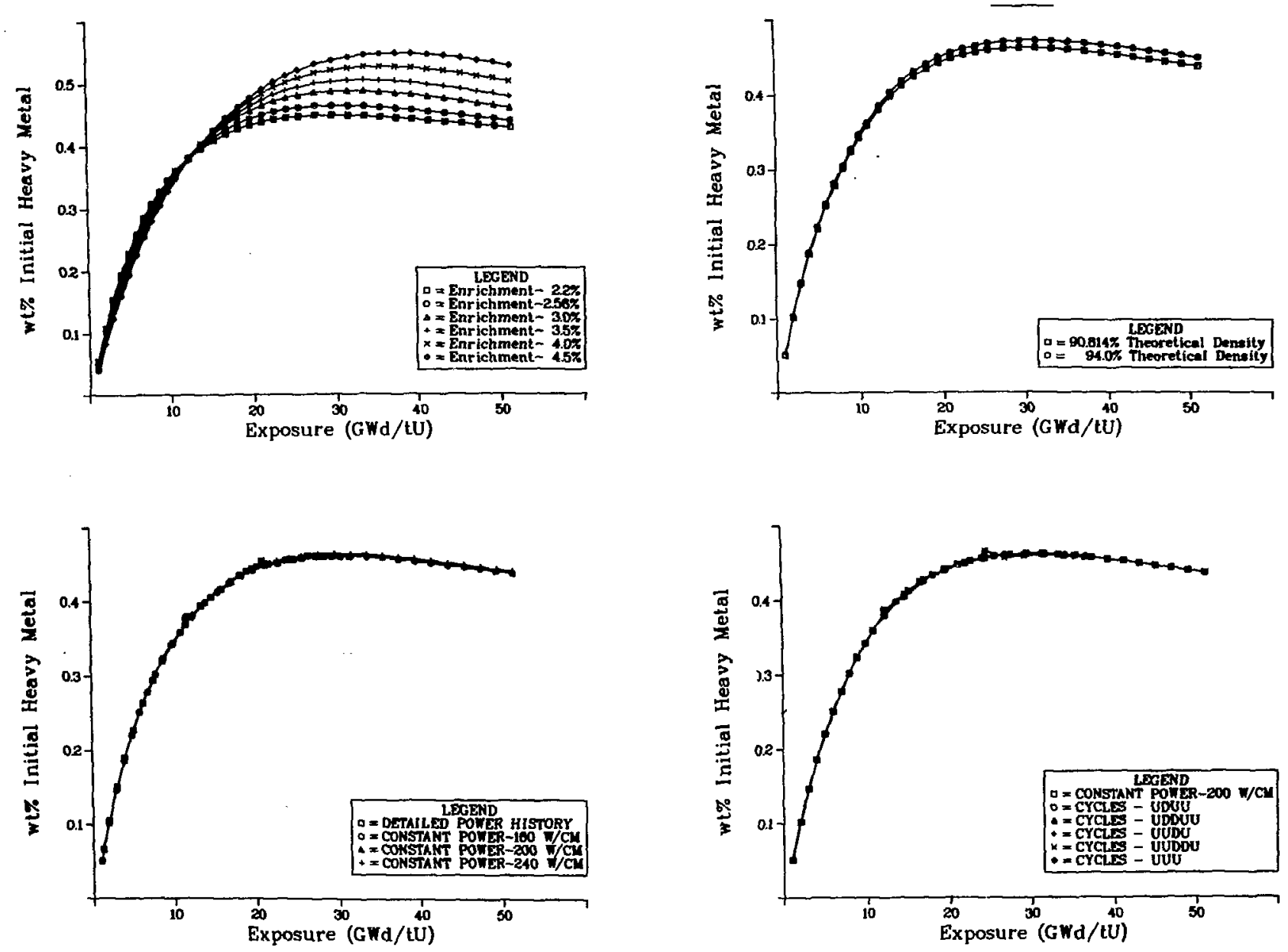

Fig. D-3.

Sensitivity of ${ }^{239} \mathrm{pu}$ to various reactor parameters as a function of exposure. 

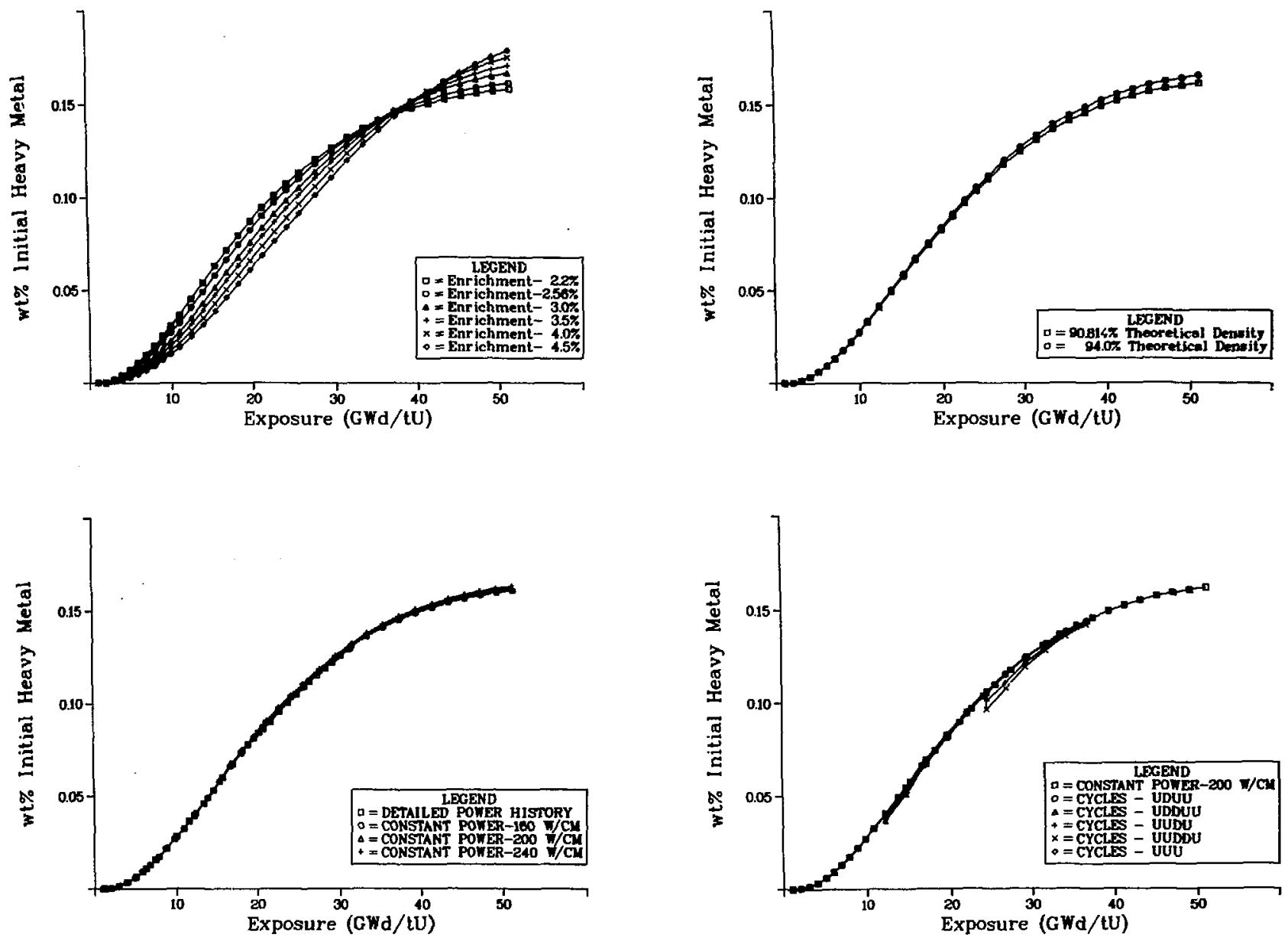

Fig. D-4.

Sensitivity of ${ }^{241} \mathrm{Pu}$ to various reactor parameters as a function of exposure. 

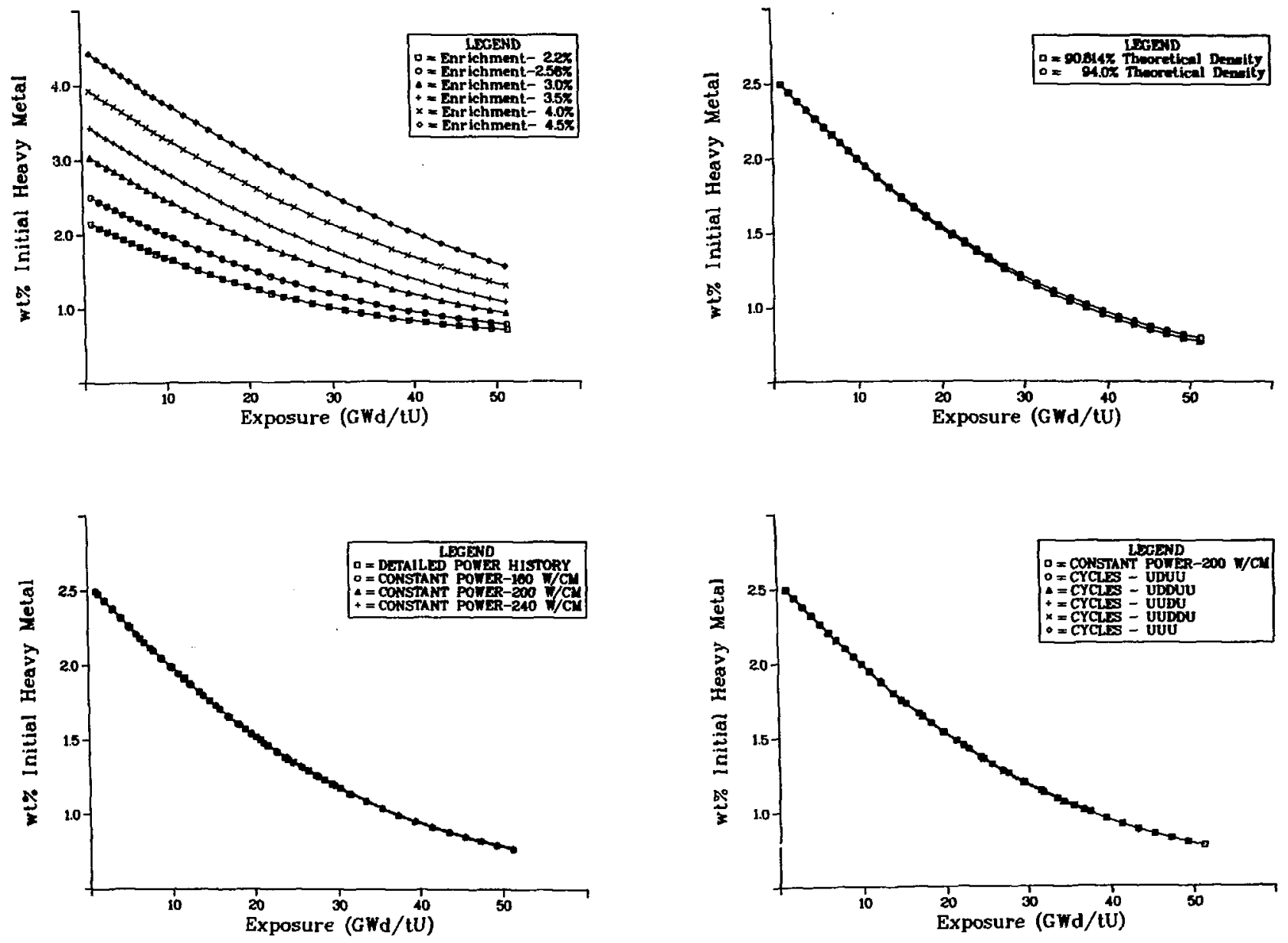

Fig. D-5.

Sensitivity of total fissile material to various reactor parameters as a function of exposure. 

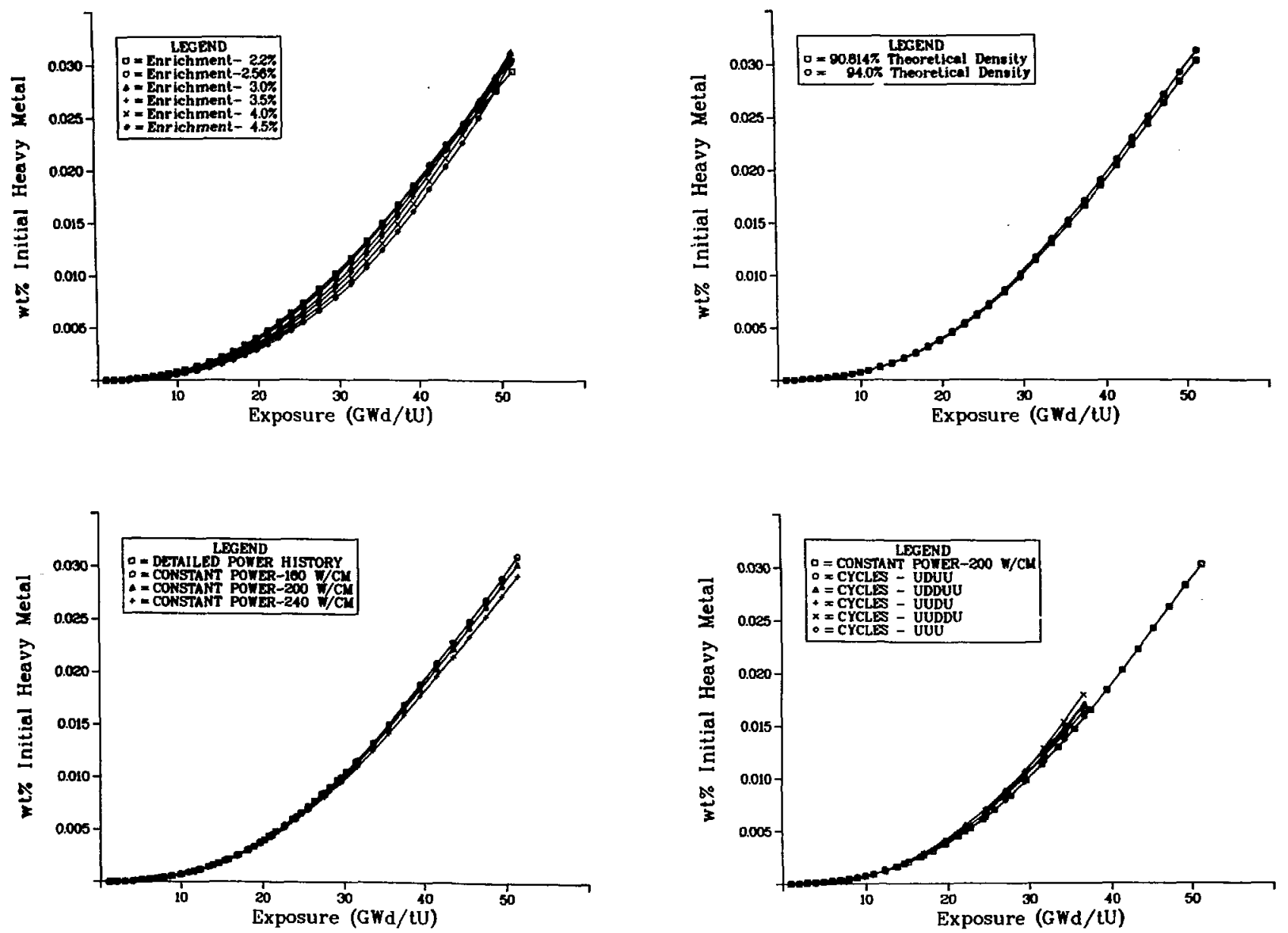

Fig. D-6.

Sensitivity of $238 \mathrm{pu}$ to various reactor parameters as a function of exposure. 

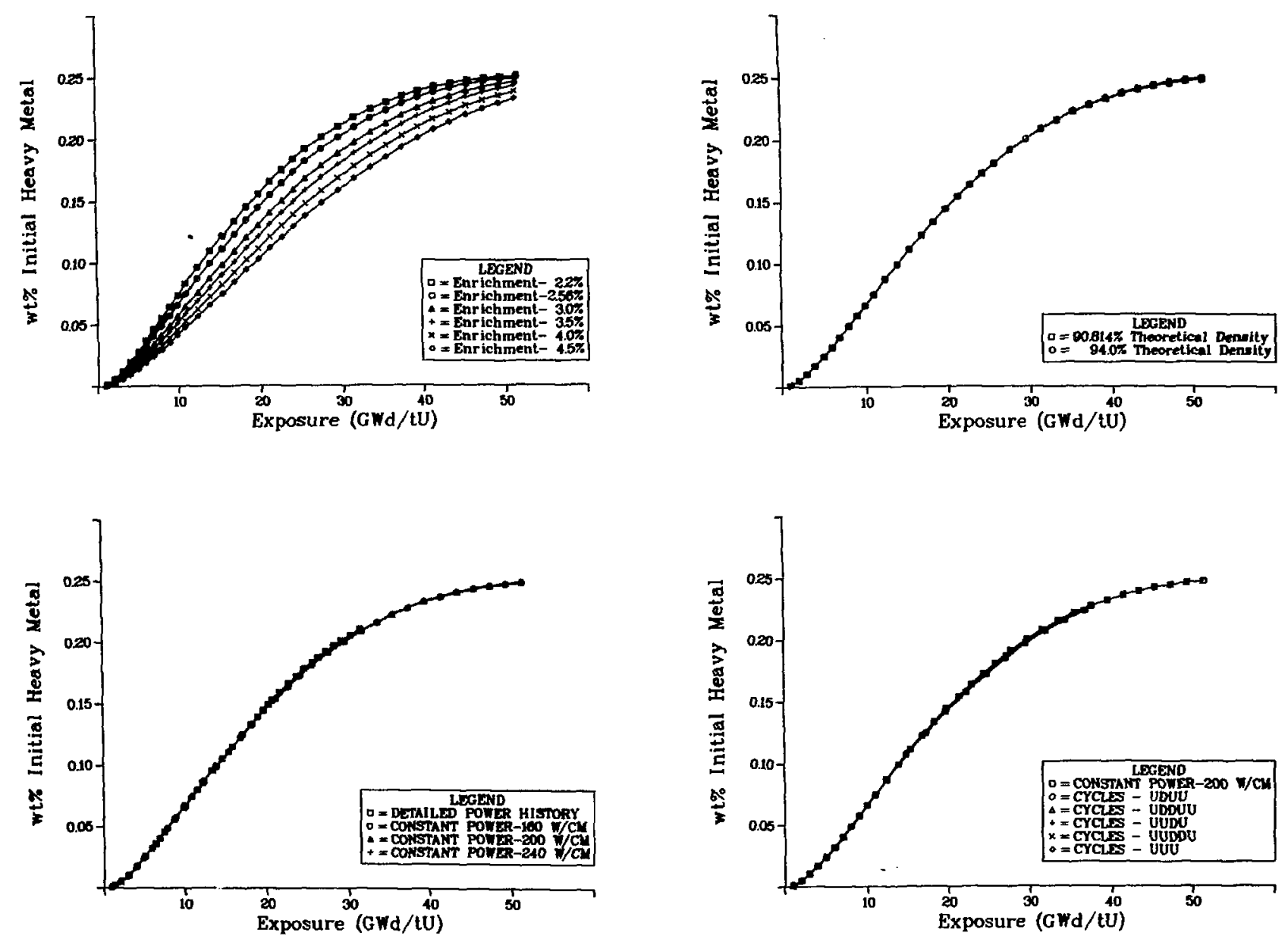

FIg. D-7.

Sensitivity of ${ }^{240} \mathrm{Pu}$ to various reactor parameters as a function of exposure. 

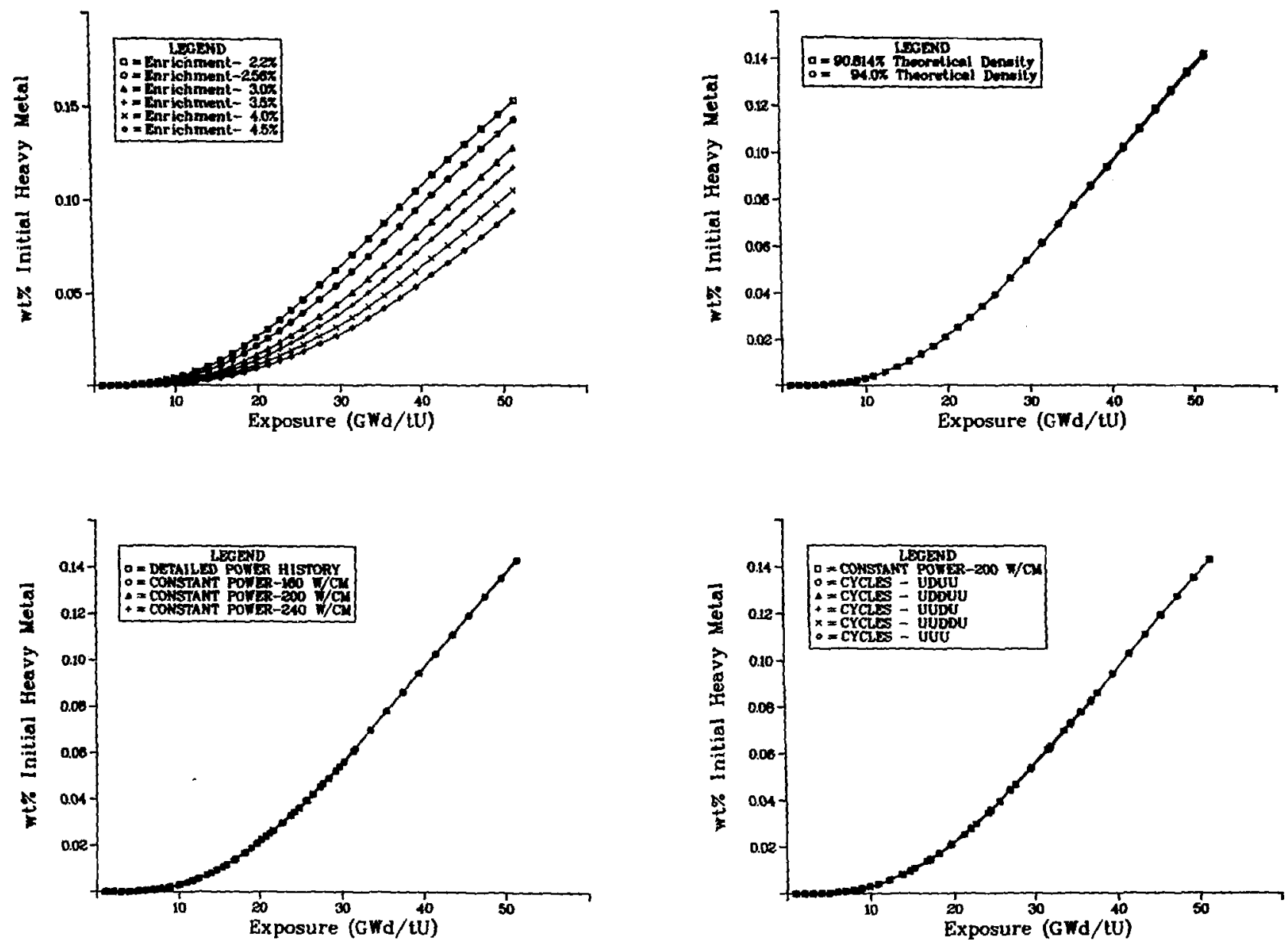

Fig. D-8.

Sensitivity of 242 pu to various reactor parameters as a function of exposure. 

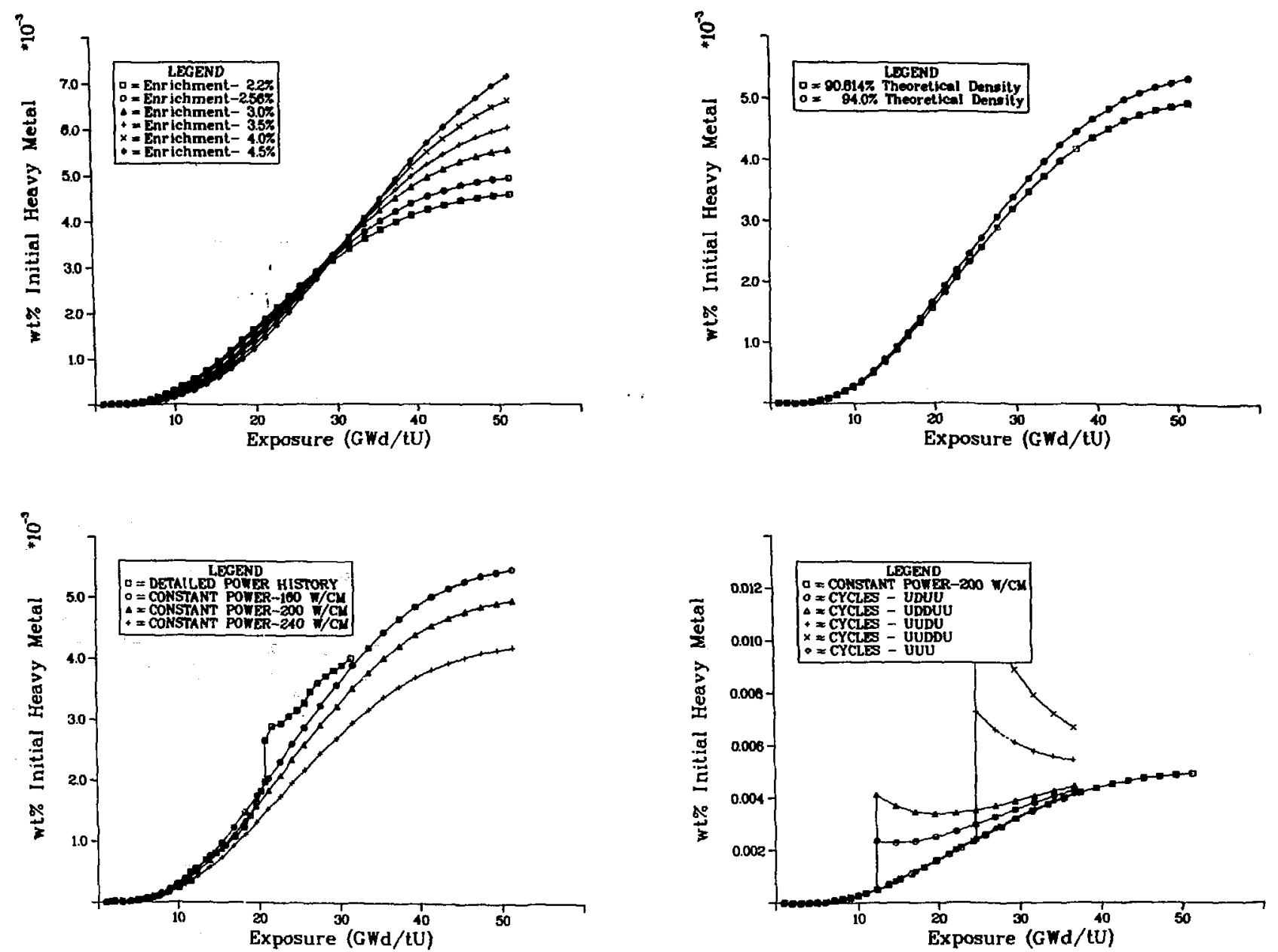

Fig. D-9.

Sensitivity of ${ }^{241} \mathrm{Am}$ to various reactor parameters as a function of exposure. 

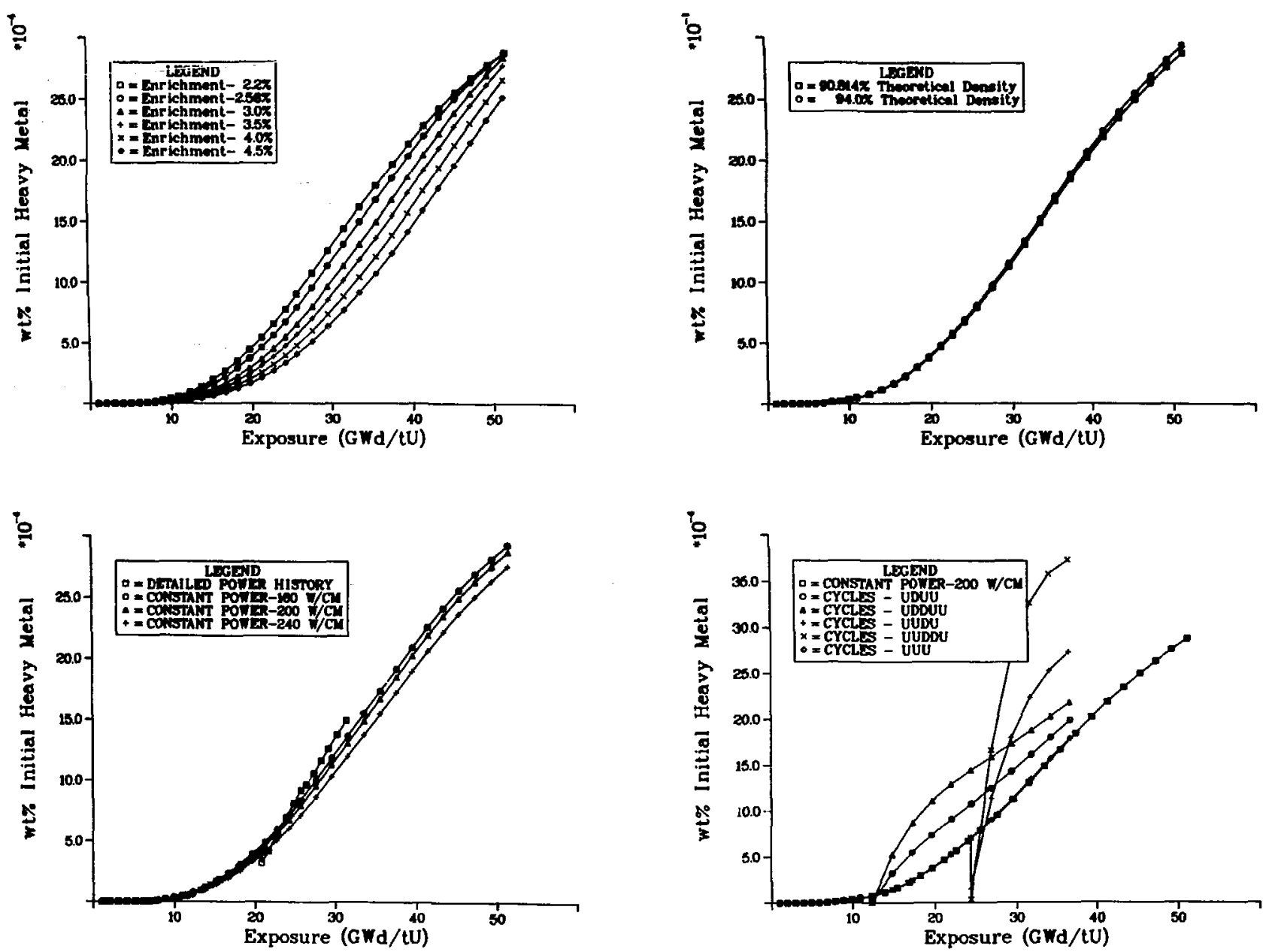

Fig. D-10.

Sensitivity of ${ }^{242} \mathrm{Cm}$ to various reactor parameters as a function of exposure. 

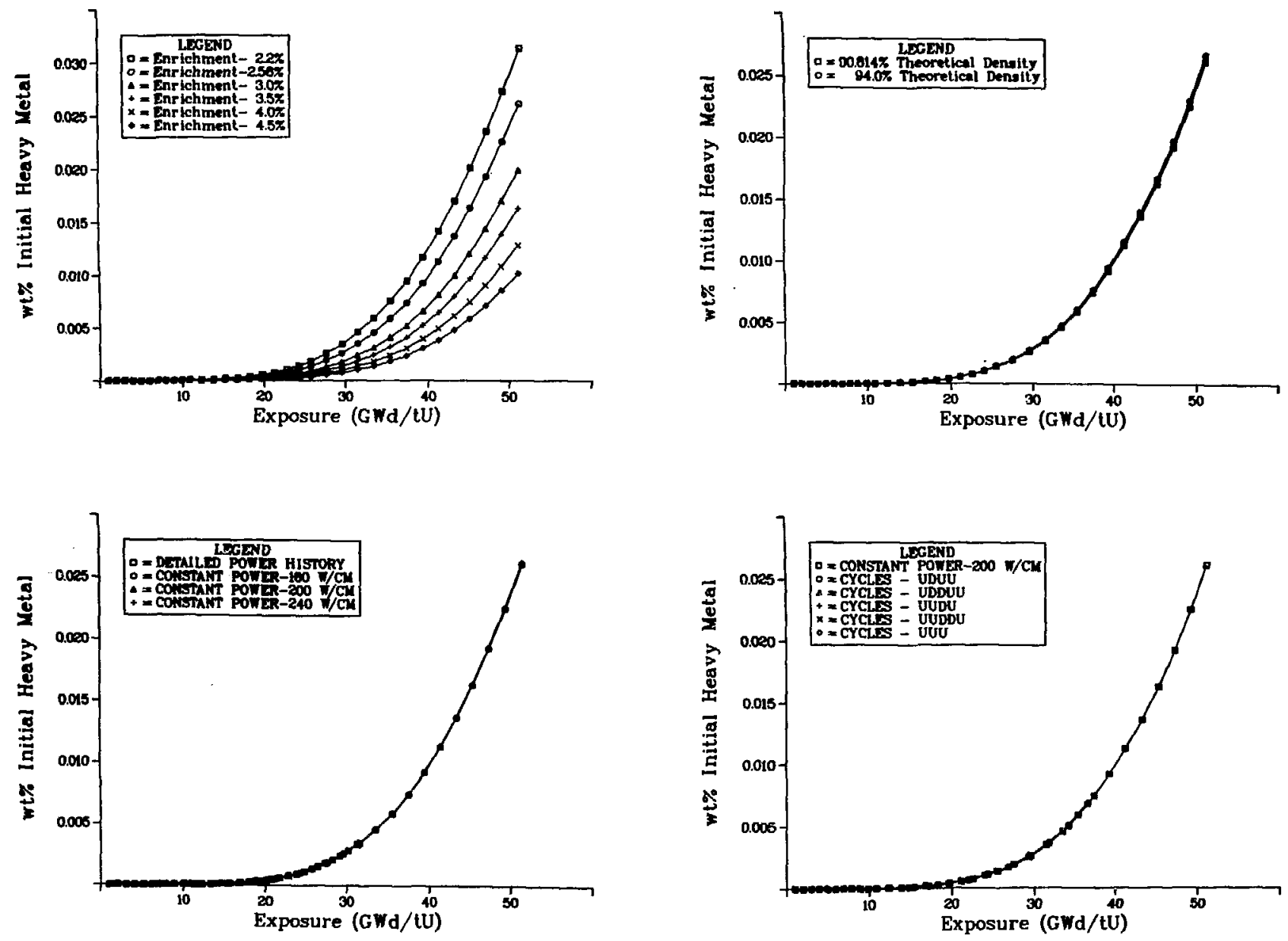
with 180 and do not include any multiplication or absorption within the fuel. Transport of these source neutron from their birth in the fuel ansembly to a detector outaide the assembly is currently being Investigated. Result. of neutron yield calculations are shown in Figs. D-12 through D-14 for exposures of $10.86,19.72$, and $51.20 \mathrm{GWd} / \mathrm{tU}$, respectively. For all these exposures, the curium 1sotopes are the primary neutron producers. At low exposure $(<10 \mathrm{Gd} / \mathrm{tU})$, the plutonium-americium isotopes contribute significantly to the neutron rate because the curium is only beginning to be produced. For higher exposures, the neutron rate is almost totally doninated by the curium 1sotope:. In the $10-35 \mathrm{GWd} / \mathrm{tU}$ exposure range, both ${ }^{242} \mathrm{~cm}$ and ${ }^{244} \mathrm{on}$ contribute to the neutron source until the ${ }^{242} \mathrm{Cm}$ decays away. For exposures above $35 \mathrm{GNd} / \mathrm{tU}$, the ${ }^{244} \mathrm{~cm}$ concentration becomes so large compared to ${ }^{242} \mathrm{~cm}$ that most of the neutrons come from ${ }^{244} \mathrm{~cm}$ regardless of the cooling time. For reprocessed fuels with the curium isotopes removed, the principsi neutron sources would be the plutonium isotopes and $241_{\text {Amm. The }}$. The ${ }^{241}{ }_{\text {Am }}$ contribution increases with cooling time as the ${ }^{241} \mathrm{Pu}$ decays to ${ }^{241} \mathrm{Am}$ with a $14.3-\mathrm{yr}$ half-life.

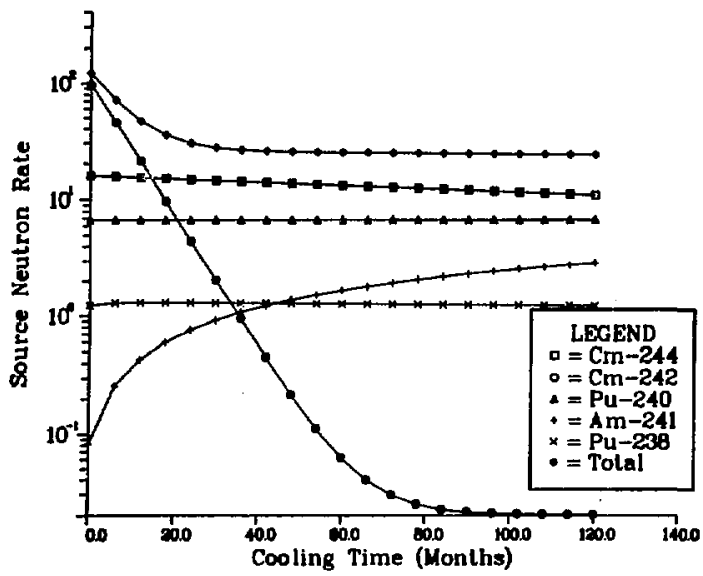

Fig. D-12.

Neution source rates for the five most proninent neutron-emitting isotopes and an expomire of $10.860 \mathrm{GWd} / \mathrm{tU}$.

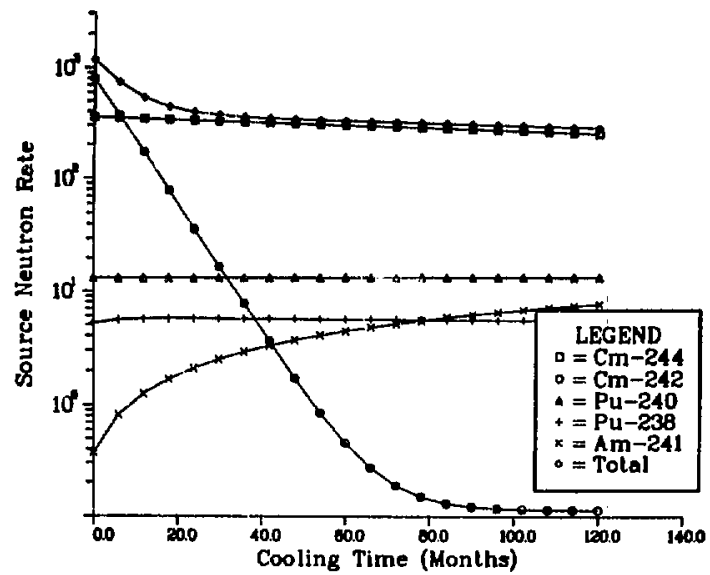

Fig. D-13.

Neutron source rates for the five most prominent neutron-emitting isotopes and an exposure of $19.717 \mathrm{GWd} / \mathrm{tU}$.

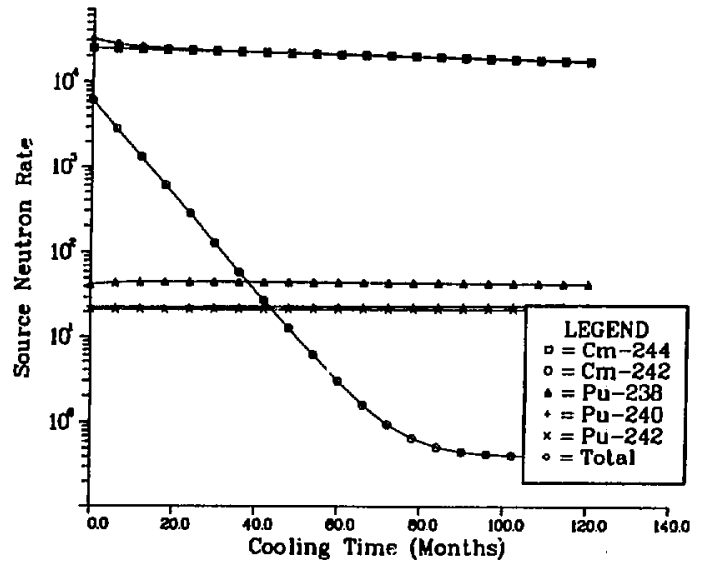

Fig. D-14.

Neutron source rates for the five most prominent neutron-emitting isotopes and an exposure of $51.201 \mathrm{GWd} / \mathrm{tU}$.

Figure D-15 compares the relative neutron rates for the detailed power history and the constant power case $(200 \mathrm{w} / \mathrm{cm})$ of the H. B. Robinson-2 data. As can be readily seen, results for the constant power case are similar to those for the detalled power history. In all subsequent comparisons, the constant power case is used as the basis for comparison. 


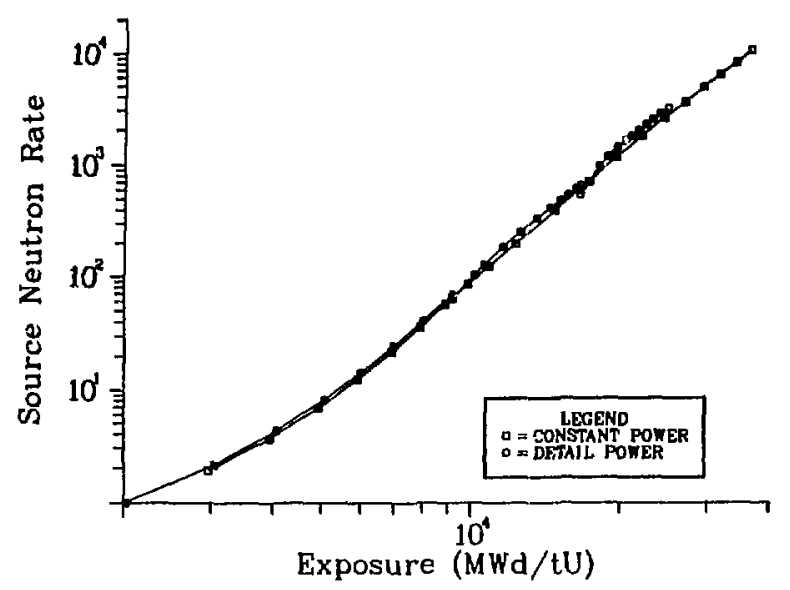

Fig. D-15.

Comparison of neutron source rates at discharge as a function of exposure for a detaij,ed power history and a continuous $200 \mathrm{w} / \mathrm{cm}$ linear power history.

The effect of varying the power level on the neutron rate at the time of discharge is shown in Fig. D-16. Differences among the three power levels decrease as the cooling time increases, with the three curves merging to one curve for very long cooling time, as shown in Fig. $D-17$. For a long cooling time, the neutron rate depends on the amount of ${ }^{244} \mathrm{~cm}$, which is essentially independent of power level. For a short cooling time, neutrons from $242 \mathrm{~cm}$ account for the dependence on power level shown in Fig. D-16.

changes in the initial mass density of the fuel material do not influence significantly the neutron source strength (Fig. D-18). Differences in tlie initial ${ }^{235} \mathrm{U}$ enrichment of the fuel material can significantly affect the neutron production rate, as is illustrated in Fig. D-19. In these cases, the power levels were maintained at $200 \mathrm{~W} / \mathrm{cm}$; therefore, the lower enrichment fuel was necessarily exposed to a higher flux as well as having slightly more $238_{\mathrm{U}}$ source material available for production of the transuranic lsotopes, particulerly the curium isotopes. Production of more curfum results in higher neutron source rates for lower enrichments.

Irradiation history is one of the most important parameters affesting neutron source terms.

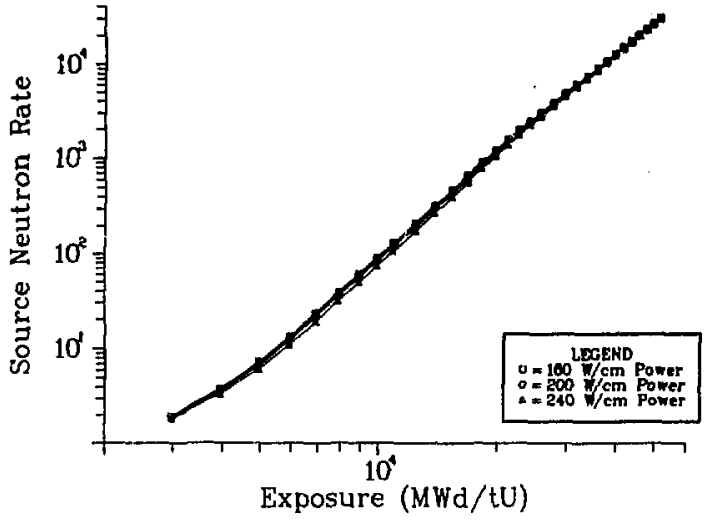

Fig. D-16.

Comparison of neutron source rates at discharge as a function of exposura for continuous power histories of $160 \mathrm{w} / \mathrm{cm}$, $200 \mathrm{~W} / \mathrm{cm}$, and $240 \mathrm{~W} / \mathrm{cm}$.

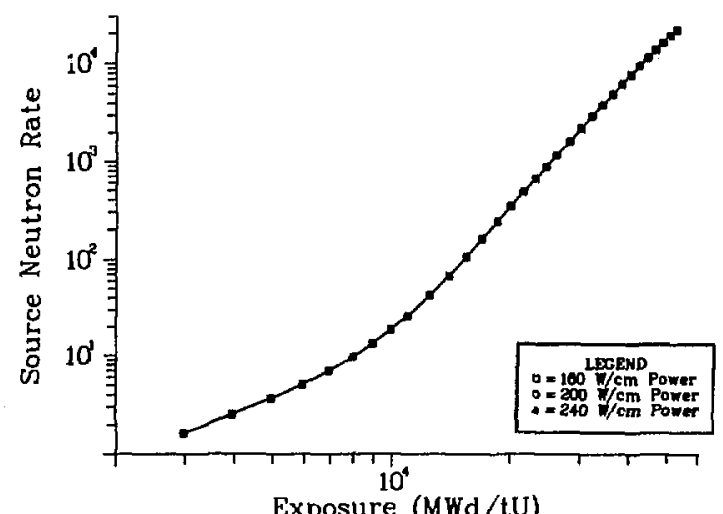

Exposure (MWd/tU)

Fig. D-17.

Comparison of neutron souxce rates at a cooling time of 36 wonths as a sunction of exposure for continuous power hietories of $160 \mathrm{w} / \mathrm{cm}, 200 \mathrm{w} / \mathrm{cm}$, and $240 \mathrm{H} / \mathrm{cm}$.

particularly for cooling times $<3 \mathrm{yr}$. Figure In-20 shows the effects of several irrediation scenarios. In these plots, a U implies a l-yr cyrle at full power and a $D$ impliea a $1-y r$ downtixne. The relative neutron rates are dramatically altered by the different frradiation histoxien. even though the total exposures are identicnl. The principal cause of these perturbations is the buildup of the ${ }^{242} \mathrm{~cm}$ isotope. Plutonium-241, with a half-1ife of $14.35 \mathrm{yr}$, is a precursor of 

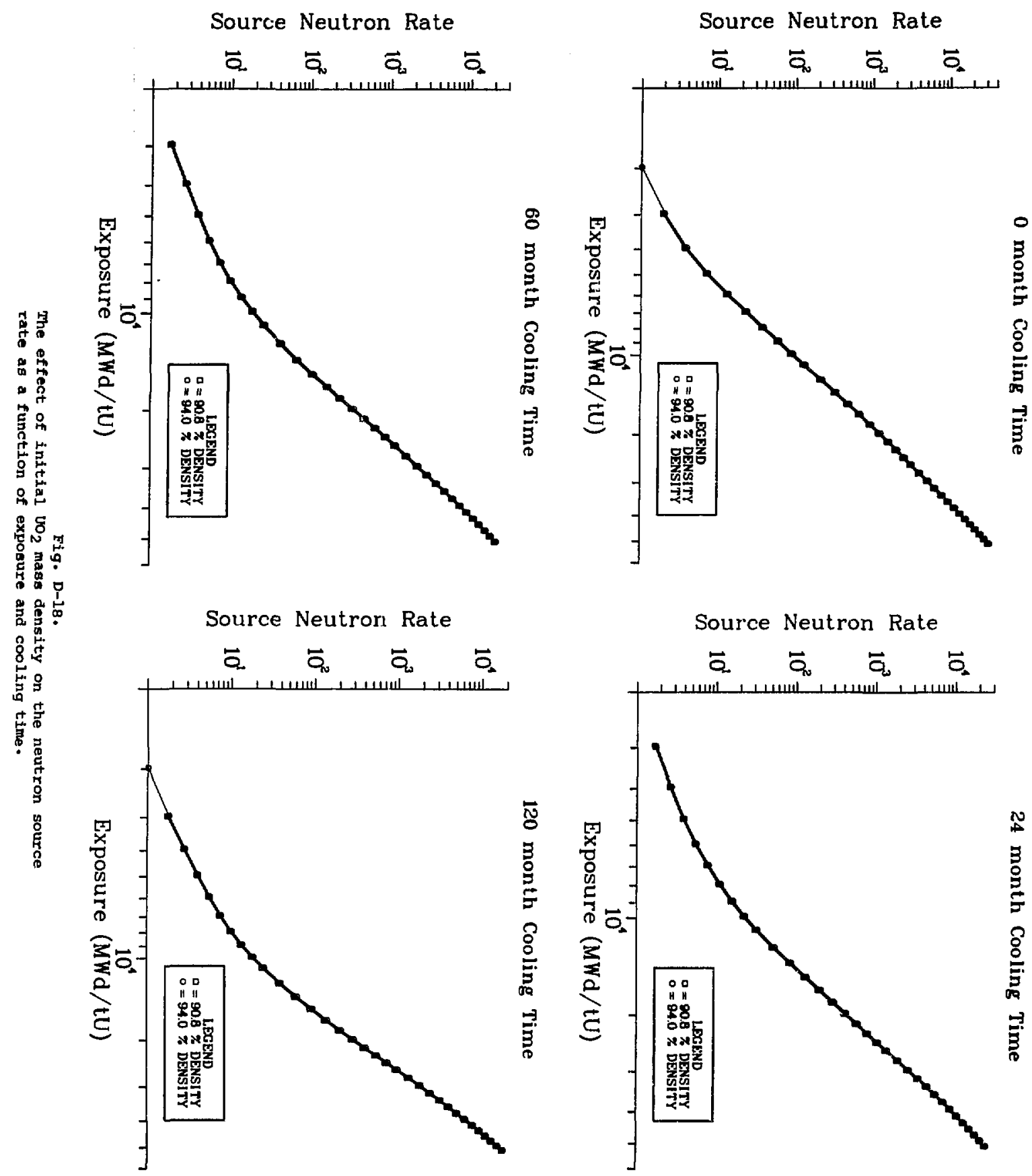

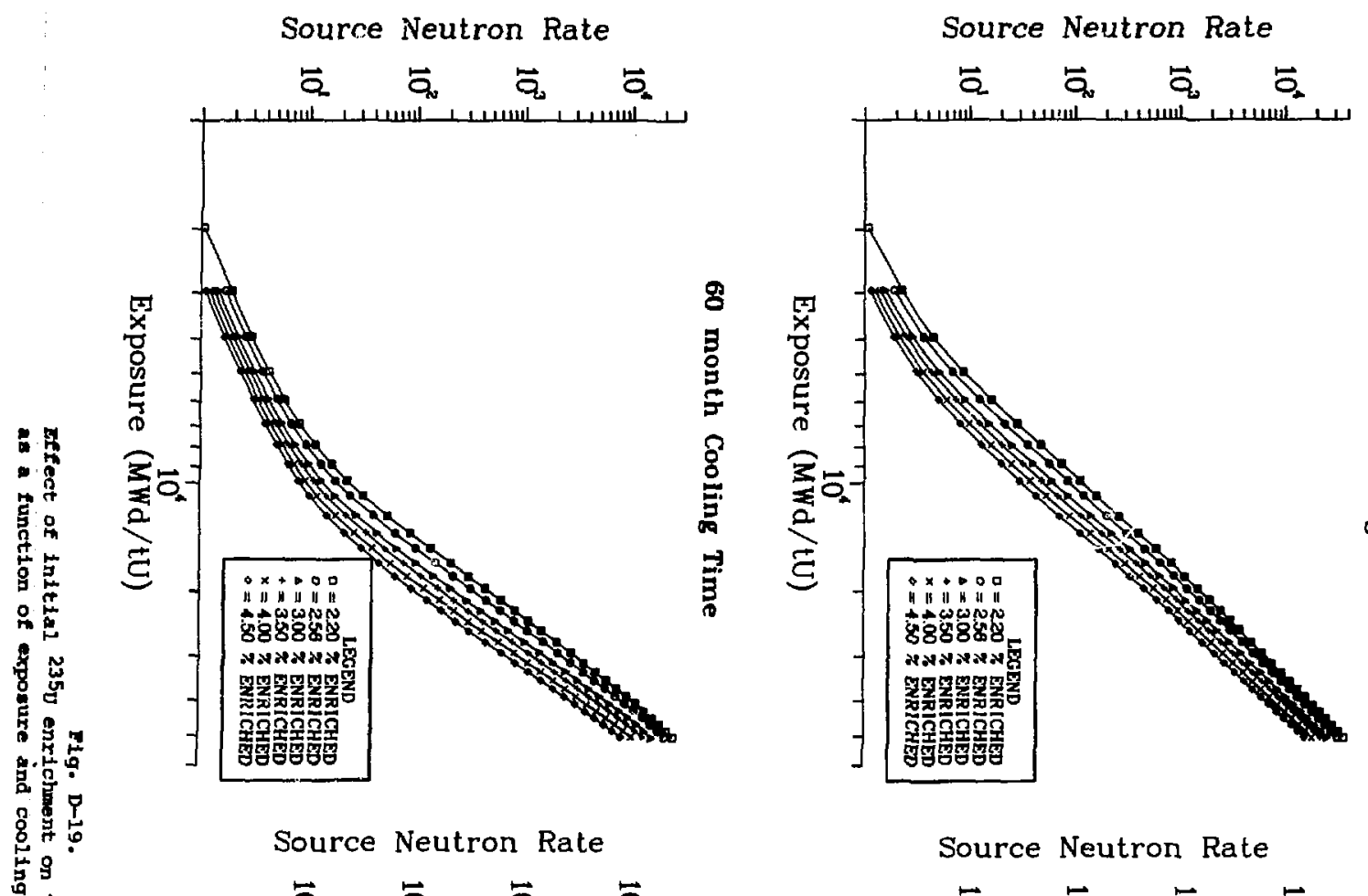

0
5
0
0
8
0
0
0
0
0
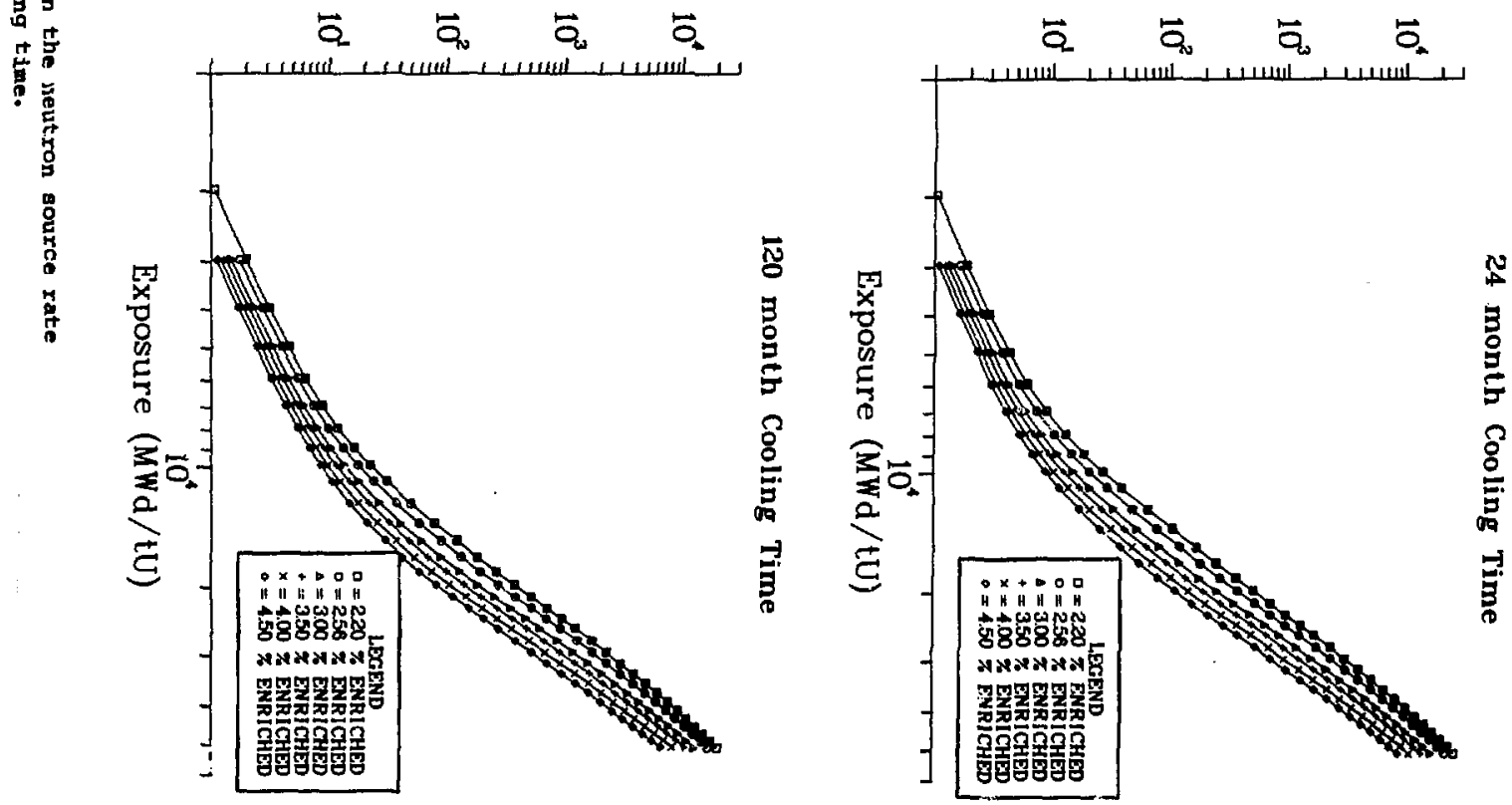

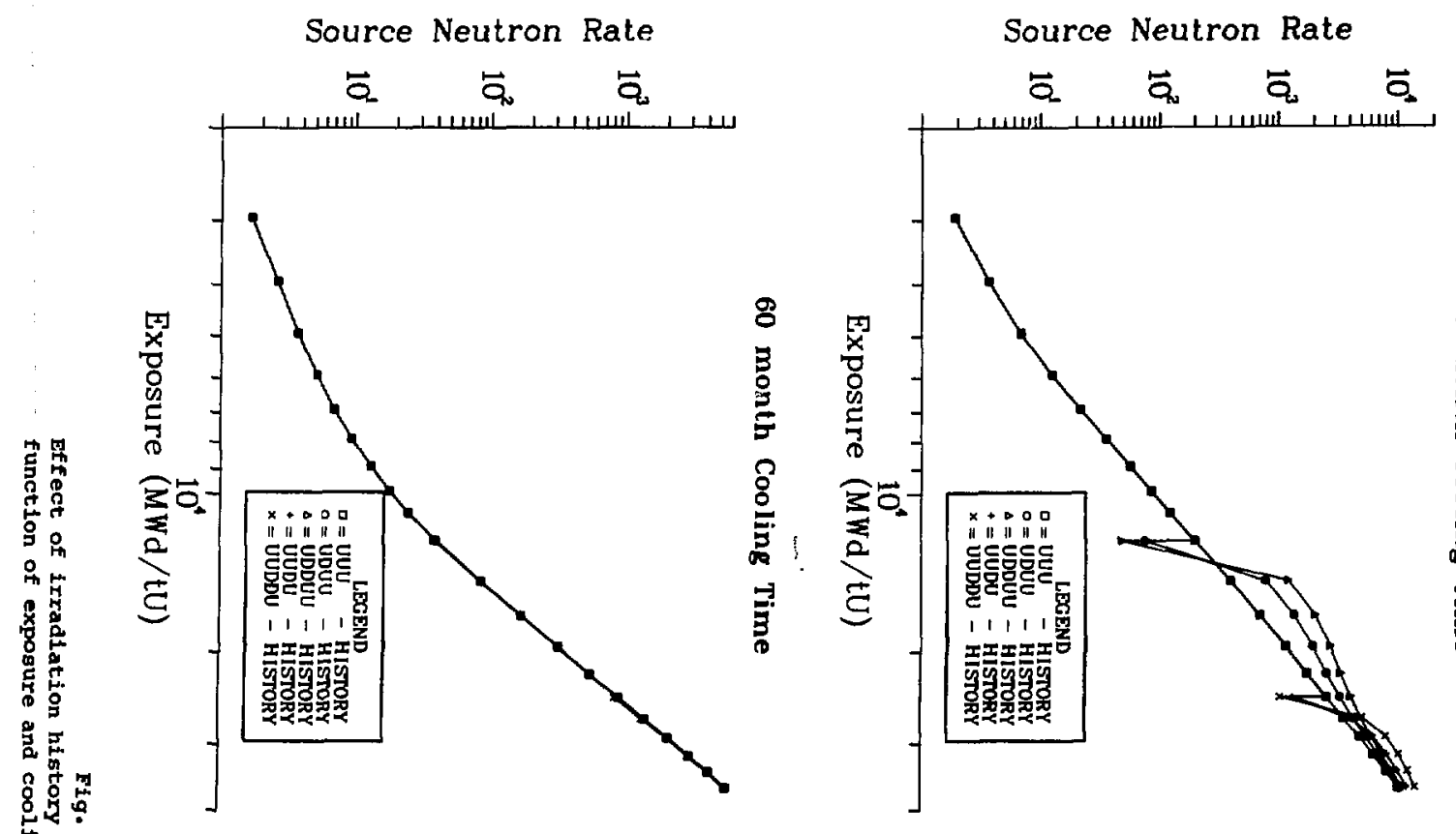

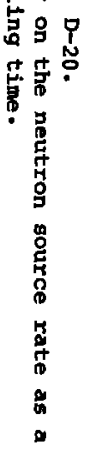
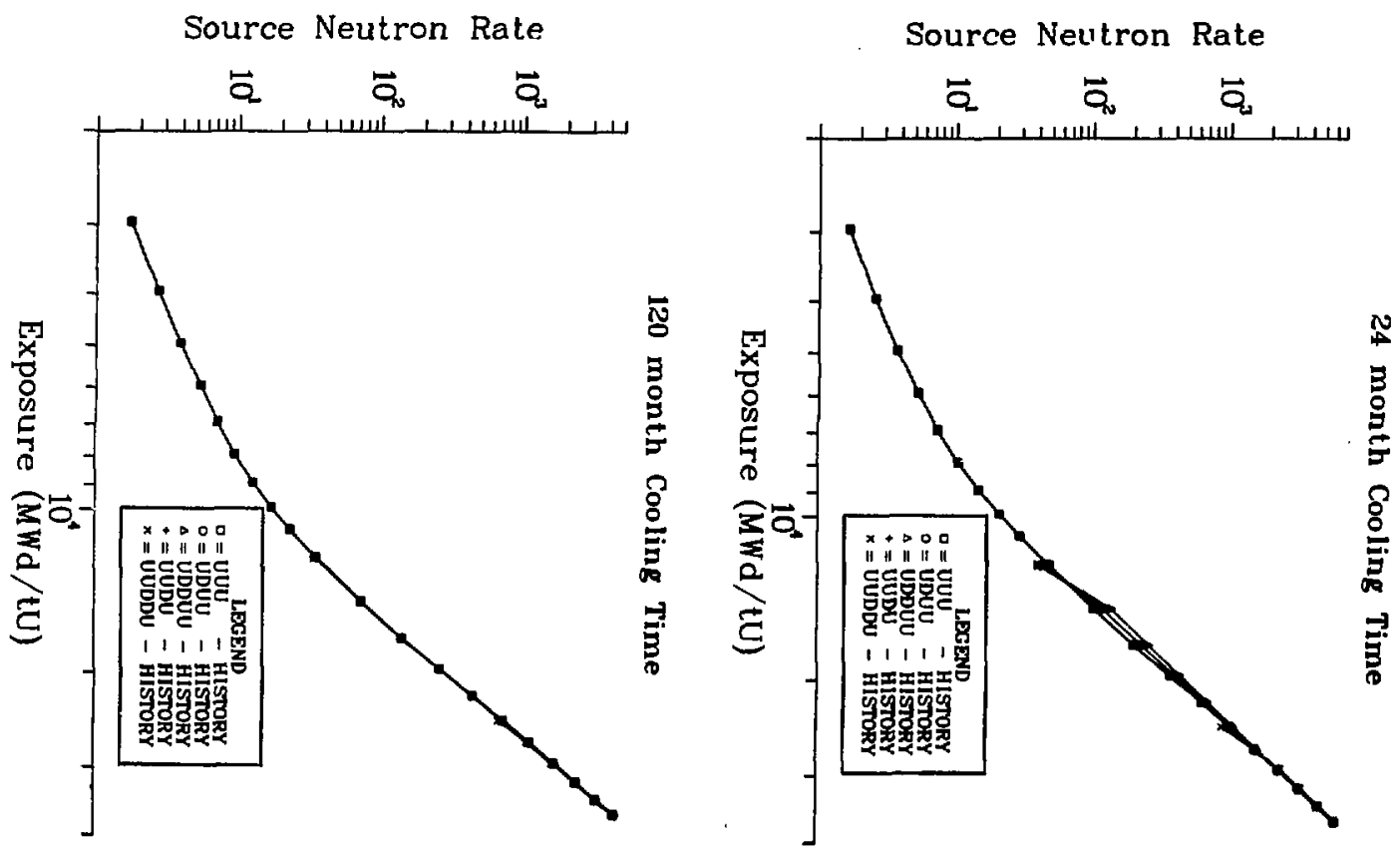
${ }^{241}$ An $\left(t_{1 / 3}=132 y x\right)$, which captures a neutron and produces $242 \mathrm{Am}$, which decays with a $16.01 \mathrm{~h}$ half-iffe to ${ }^{242} \mathrm{~cm}$. For a ignificant downtime, the ${ }^{241} \mathrm{Am}$ inventory increanes, thereby producing more source material for the production of $242 \mathrm{~cm}$. The regulting influence upon the relative neutron rates becomes less important as the cooling time Increases, with all canes merging after $3 \mathrm{yr}$.

The above data illustrate the important influence of various fuel parameters and irradiation histories upon the neutron sources in irradiated fuel assemblies. To interpret correctly passive neutron measurements of fuel assemblies, some information about the initial fuel material is necessary, and for short cooling times $\ll 36$ months), additional information is required about the irradiation historiea.

For irradiated fuel assemblies that have cooled sufficiently to allow the decay of ${ }^{242} \mathrm{Cm}$ to an insignificant level, the neutron emisation rate and subsequent detector count rate are directly proportional to the ${ }^{244} \mathrm{Cm}$ density. As shown in Figs. D-21 and D-22, ${ }^{244} \mathrm{Cm}$ density can be correlated with plutonium content. In Fig. $\mathrm{D}-21, \quad{ }^{244} \mathrm{Cm}$ is correlated with $\Delta \mathrm{Pu}=$ Total Pu - ${ }^{239}$ Pu. In Fig. D-22, the correlation is between ${ }^{244} \mathrm{~cm}$ and total plutonium. At Karlsruhe, 5 these correlations were used successfully to determine plutonium content in irradiated fuel assemblies. As shown in Fig. D-21, APu vs ${ }^{244} \mathrm{Cm}$ is an excellent correlation because there is little sensitivity to parameters such as initial ${ }^{23.5} \mathrm{U}$ enrichment, $\mathrm{N}_{2}$ density, power level, and irradiation history. The total plutonium vo ${ }^{244} \mathrm{~cm}$ correlation show in Fig. D-22 is basically insensitive to all parameters except initial ${ }^{235} \mathrm{v}$ enrichment. Thus, if corrections are made for initial ${ }^{235} \mathrm{v}$ enrichment, these two correlations could be used for determining plutonium content from passive neutron measurements. Other correlattons are possible and may be developed to relate neutron rates to various irradiated fuel parameters.
III. GANAM-RAY SIGNALS

Measurable apectral gama-ray algnatures from irradiated bolling-water-reactor (BWR) and pressurized-water-reactor (PWR) fuels come primarily from flasion products. These signatures can be used to verify operator-declared values of exponure and cooling time. 6 Varlous gamm-ray signatures and isotopic ratios have been invertigated calculationally. Some results of these calculation. are shown in Figs. D-23 through D-25. In Fig. D-23, ${ }^{137} \mathrm{Cs}$ is relatively independent of the parameters investigated. Because of these characteristics and a relatively long half-ilfe (30.1 $\mathrm{yr}$. measurement of ${ }^{137} \mathrm{Ce}$ concentration is one means for determining exposure. ${ }^{6}$ in Fig. D-24, ${ }^{134} \mathrm{Cg}$ has a very short half-1ife $(2.06 \mathrm{yr})$ and is therefore very sensitive to shutdown periods. Cesium-134 is also more senaitive than ${ }^{137} \mathrm{Cs}$ to initial ${ }^{235} \mathrm{U}$ enrichment. Europium-154, shown in Fig. D-25, has a half-life of $8.6 \mathrm{yr}$ and behaven similarly to ${ }^{134} \mathrm{Cs}$. Both ${ }^{134} \mathrm{Cs}$ and $154_{\mathrm{Eu}}$ are shielded isotopes in that they are not formed directly from fission. Conly an insignificant fraction of these two 1motopes are formed directly from fission.) Instead, these isotopes are produced from chains of neutron capture evente. For ${ }^{134} \mathrm{Cs}$, the chain 1 s very simple, resulting from capture in ${ }^{133} \mathrm{C}$ that comes from ${ }^{133} \mathrm{x}$ through ${ }^{133} \mathrm{xe}$. The ${ }^{154}$ wu chain $1 \mathrm{~s}$ much mare complicated, starting from ${ }^{145} \mathrm{Pr},{ }^{150} \mathrm{Nd}$, and ${ }^{148} \mathrm{Nd}$. A complete decription of the ${ }^{154}$ Eu chain 1 included in Ref. 6.

The isotopic ratios ${ }^{134} \mathrm{cs} /{ }^{137} \mathrm{Cs}$ and ${ }^{154} \mathrm{Eu} /{ }^{137} \mathrm{Ce}$ are shown in Figs, $\mathrm{D}-26$ and $\mathrm{D}-27$, respectively. Both ratios depend on initial 235 $\mathrm{U}$ enrichment. Because of the short half-life of ${ }^{134} \mathrm{Cs}$, the ${ }^{134} \mathrm{Cs} /{ }^{137} \mathrm{Cs}$ ratio is very dependent on the irradiation histary of the fuel asmenbly. Both of these ratios have been used experimentally to verify exposure and cooling times. 5

In Figs. D-28 and D-29, these two isotope ratios are plotted as a function of ${ }^{239} \mathrm{Pu}$ content for two exposure historias. The detalled irradiation history for $H$. B. Robinson includes a 

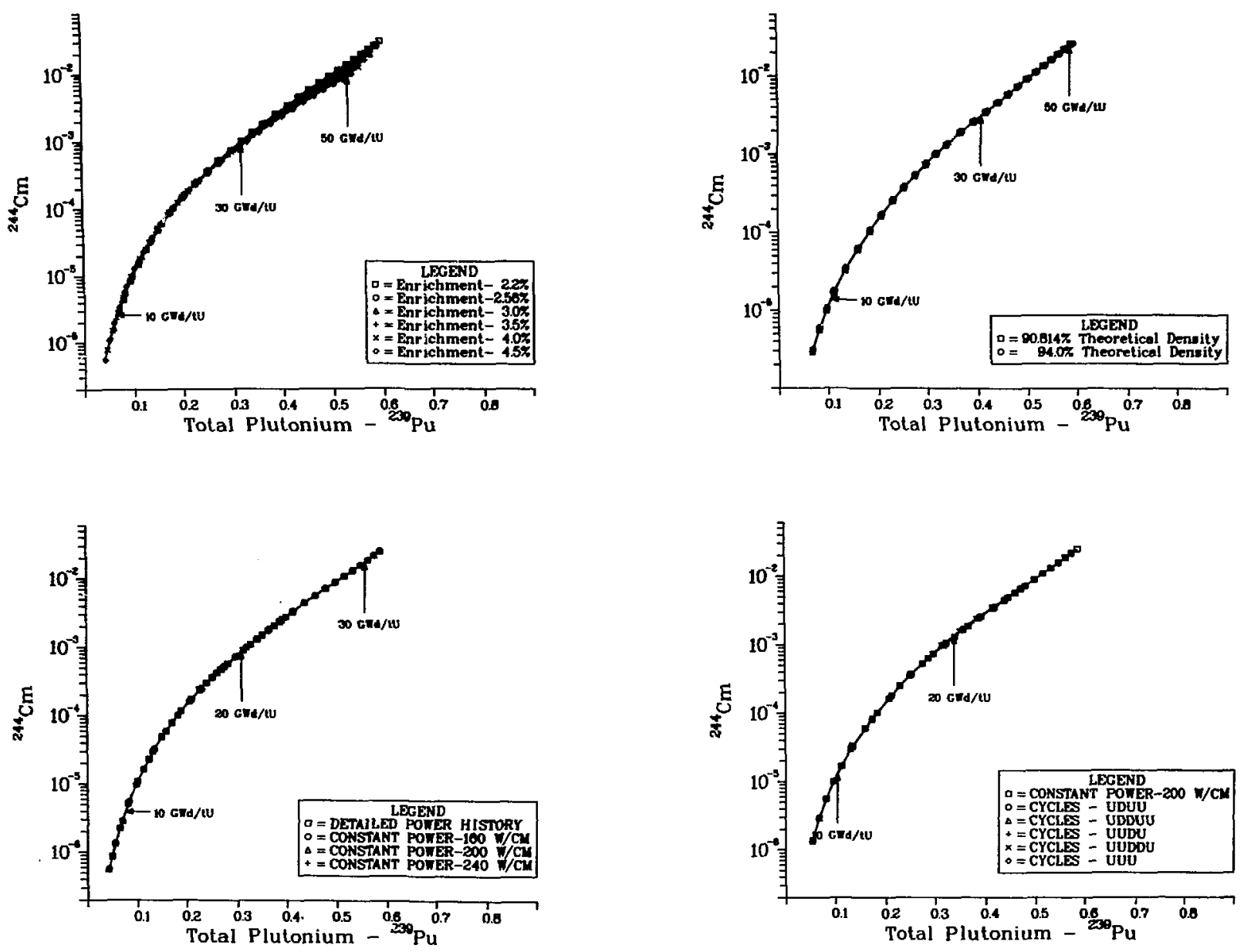

Fig. D-21.

Dependence of correlation between $244 \mathrm{Cr}$ and $\triangle \mathrm{pu}=$ total plutonium - $239 \mathrm{pu}$ on initial 235 U enrichment, initial $\mathrm{WO}_{2}$ mass density, power level, and irradiation history. 

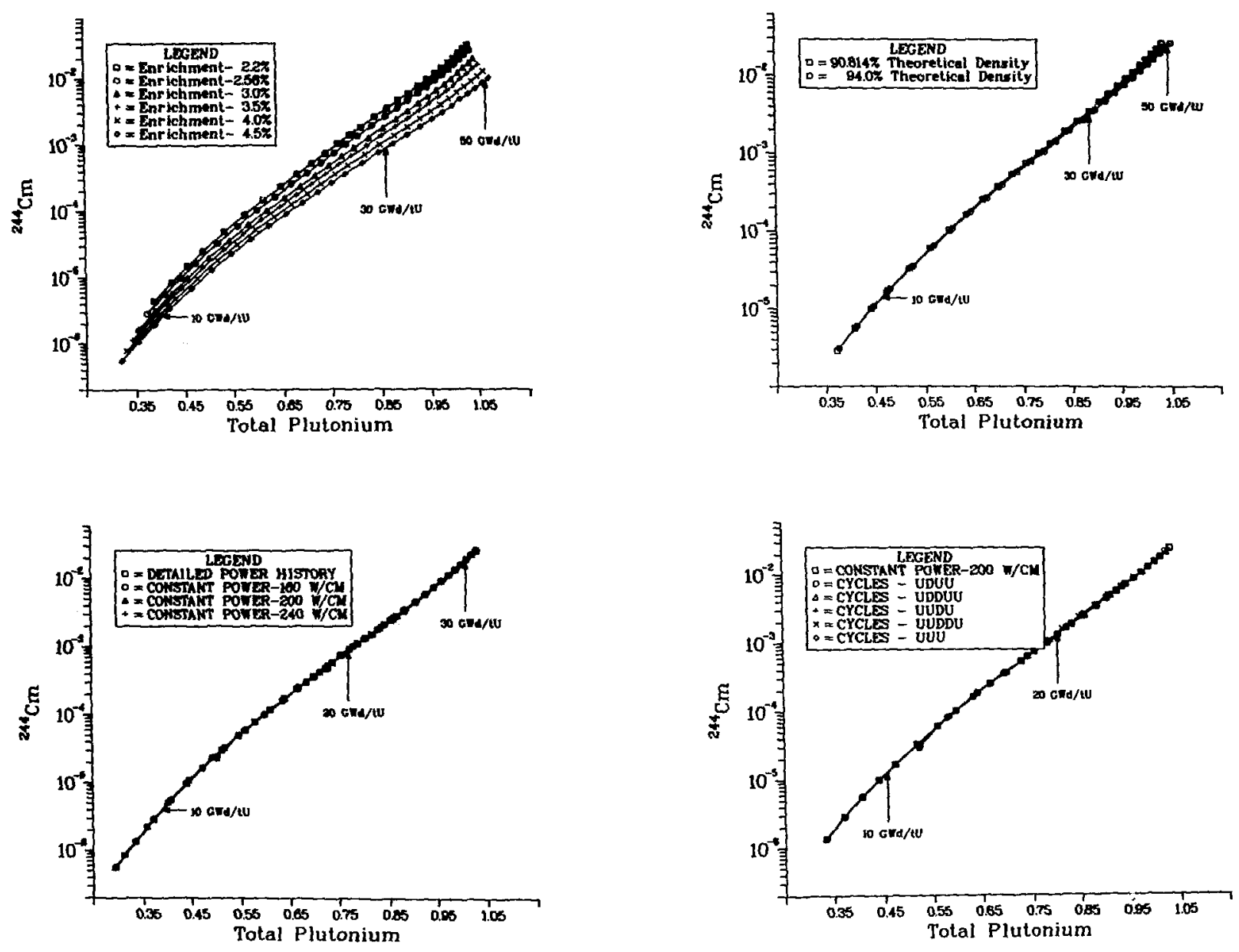

Fig. D-22.

Dependence of correlation between $244 \mathrm{~cm}$ and total plutoniun on initial $235 \mathrm{v}$ enrichnent, initial $\mathrm{UO}_{2}$ mass density, power level, and irradiation history. 

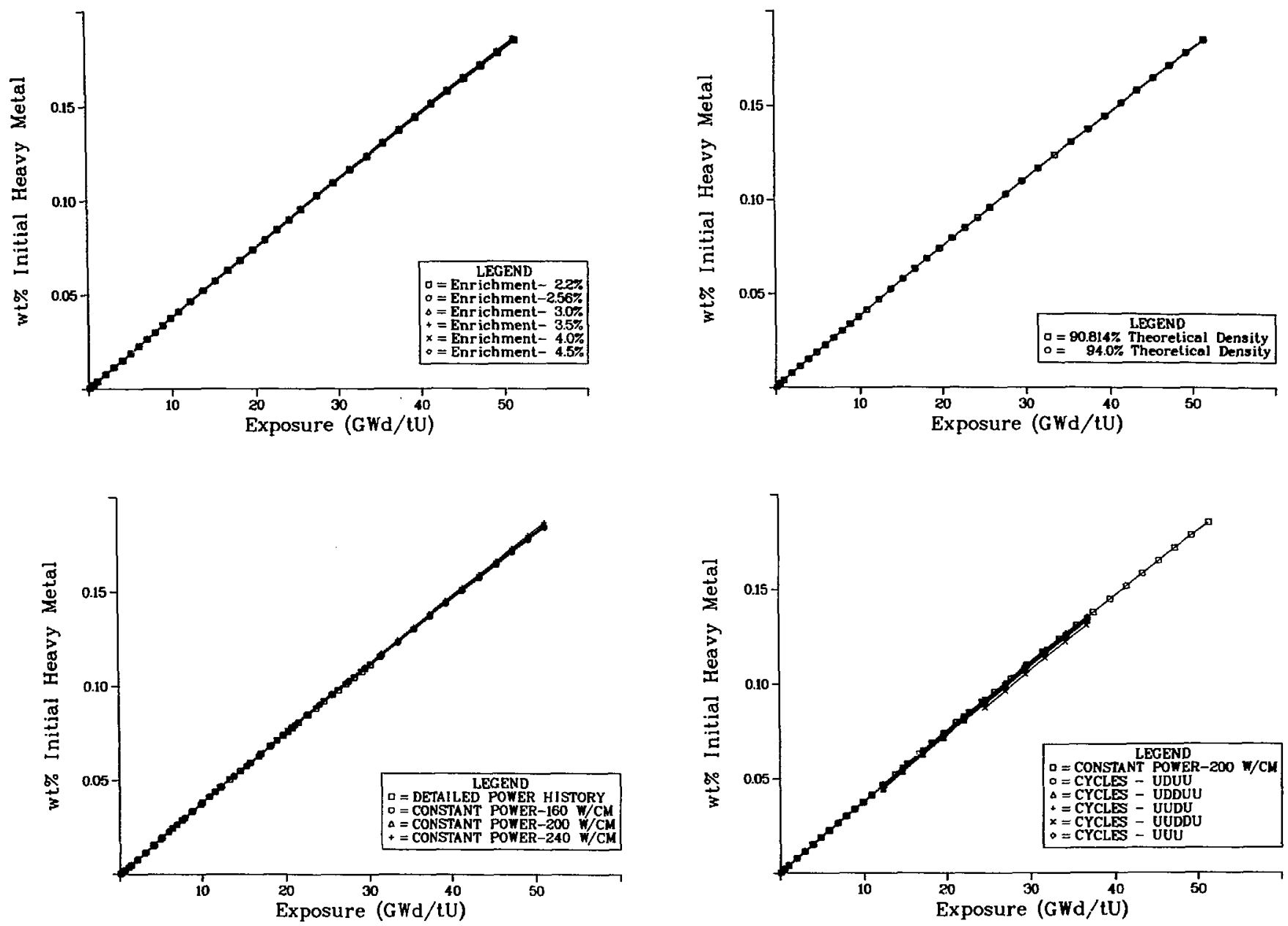

Fig. D-23.

Sensitivity of 137 Cs to various reactor parameters as a function of exposuxe. 

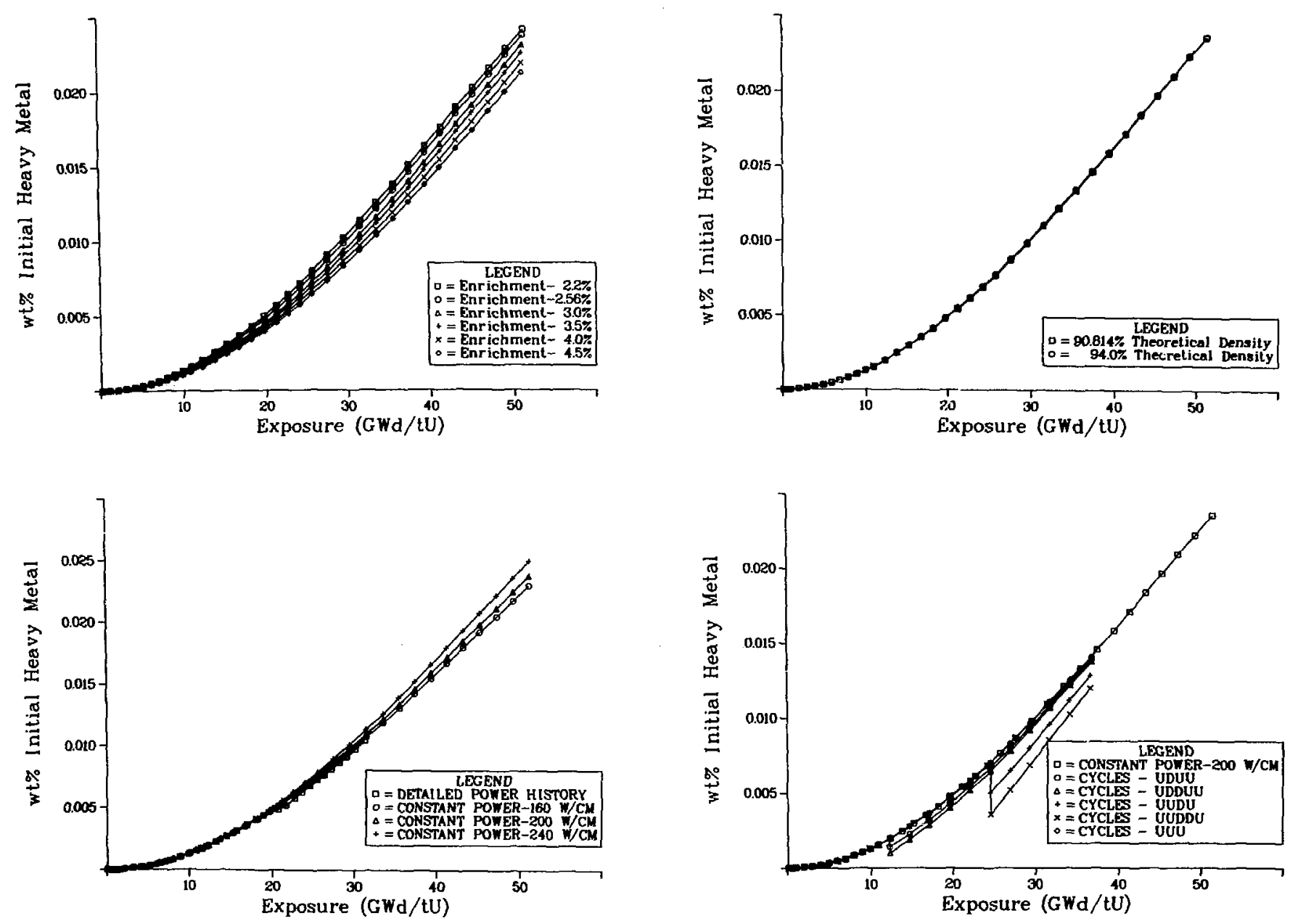

Fig. D-24.
Sensitivity of ${ }^{134} \mathrm{Cs}$ to various reactor parameters as a function of exposure. 

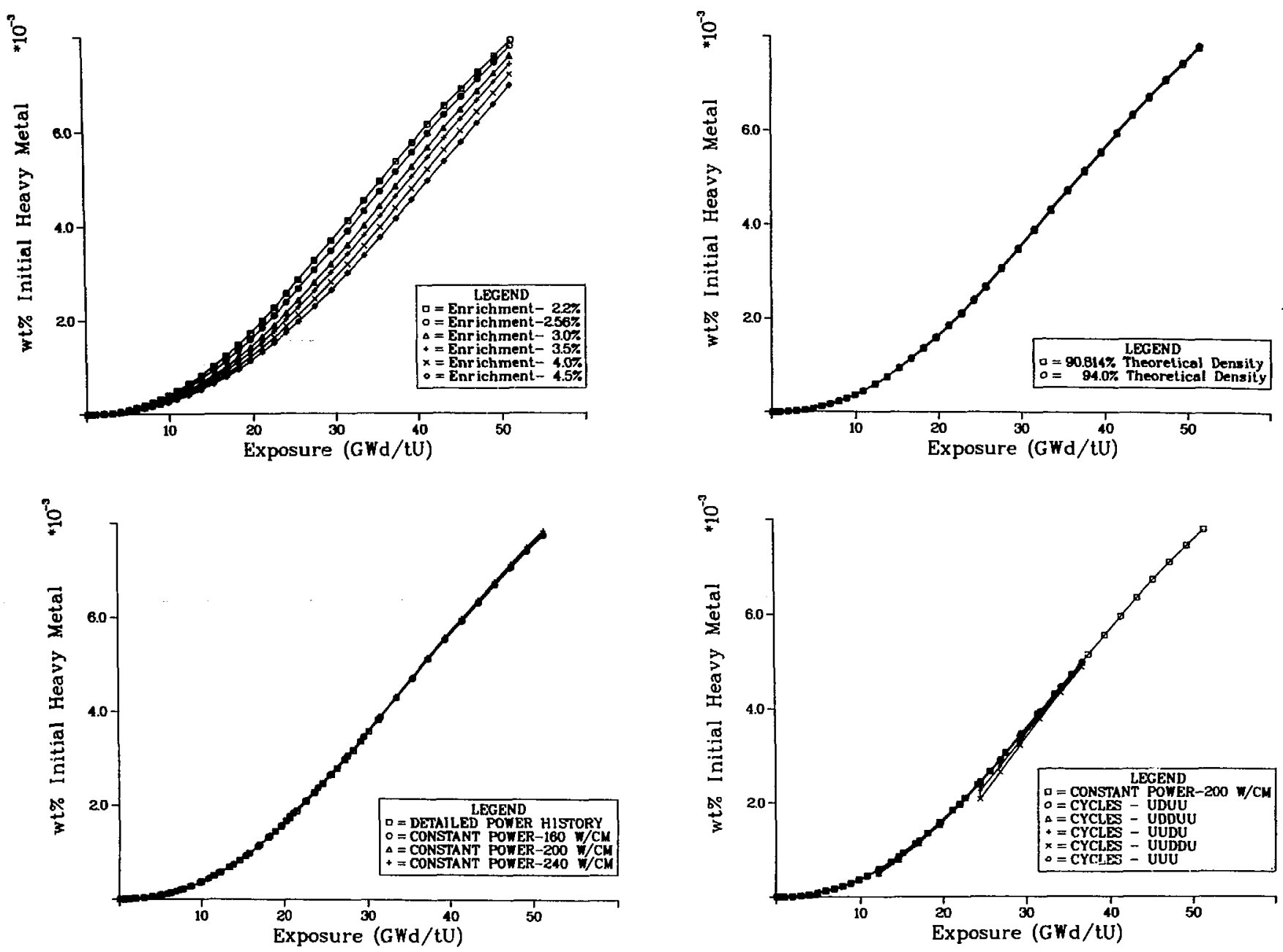

Fig. D-25.

Sensitivity of ${ }^{154} \mathrm{Eu}$ to various reactor parameters as a function of exposure. 

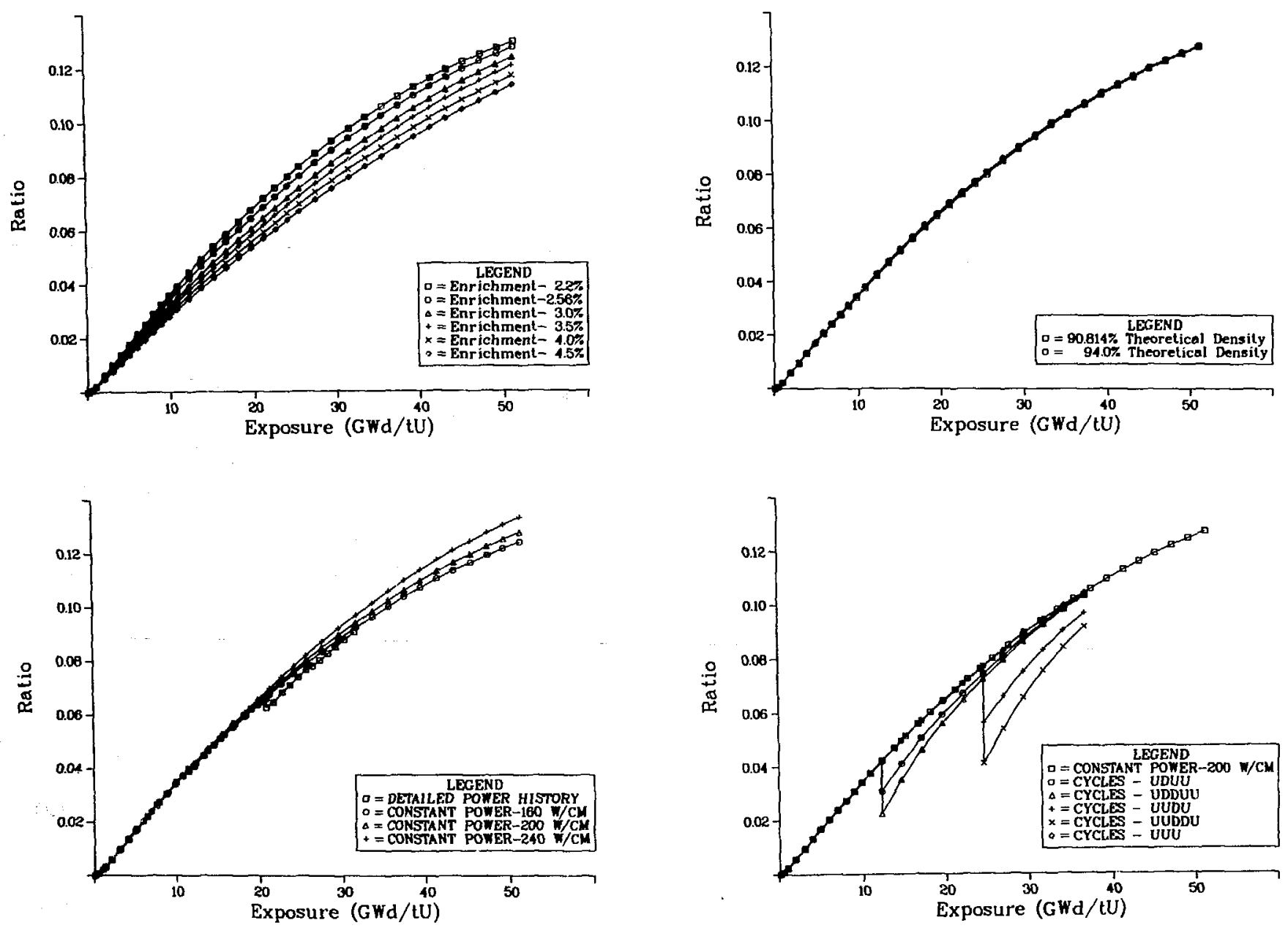

Fig. D-26.

Sensitivity of ${ }^{134} \mathrm{Cg} /{ }^{137} \mathrm{Cs}$ to various reactor parameters as a function of exposure- 

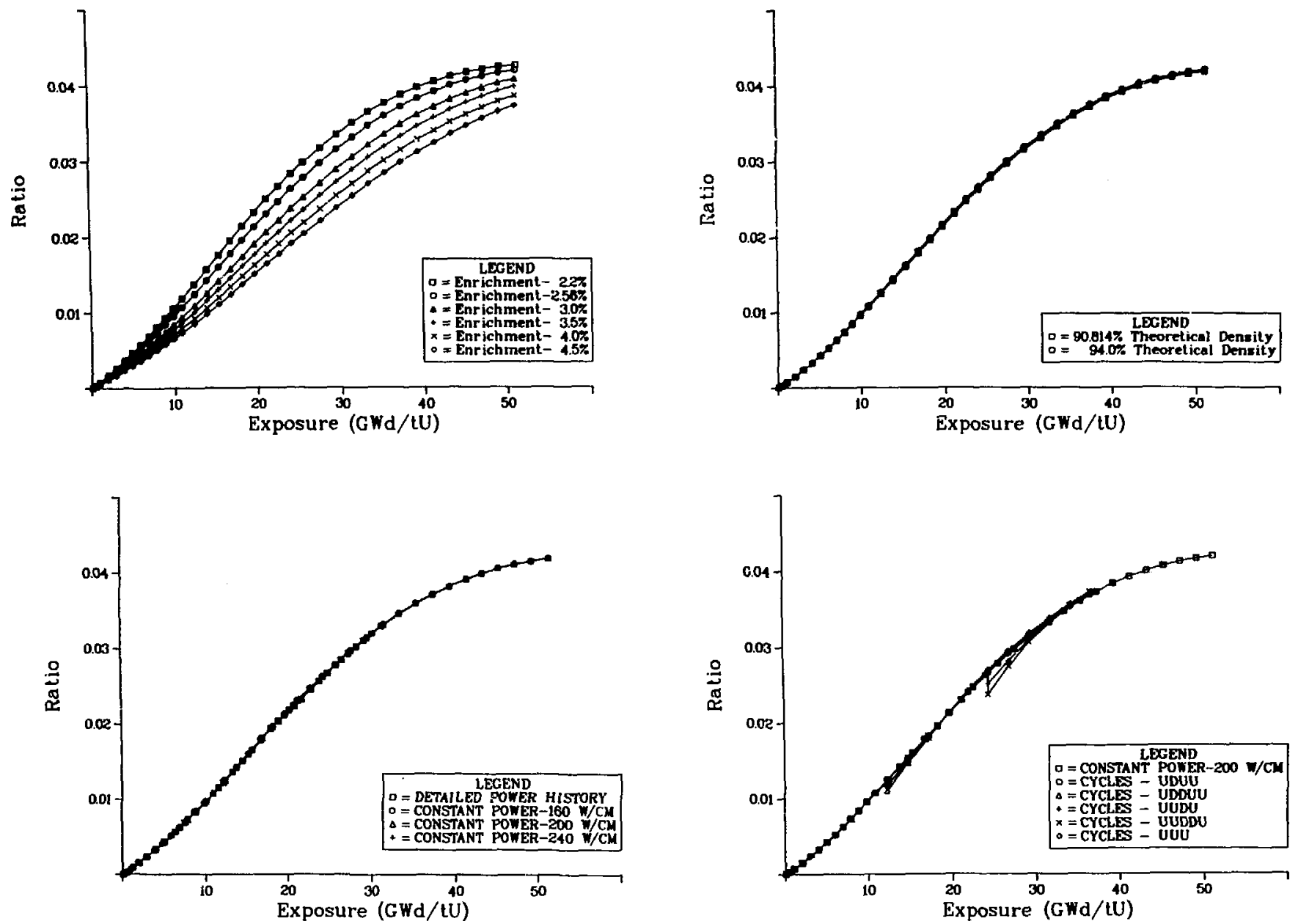

Fig. D-27.

Sensitivity of ${ }^{154} \mathrm{Eu} /{ }^{137} \mathrm{Cs}$ to various reactor parameters as a function of exposure. 

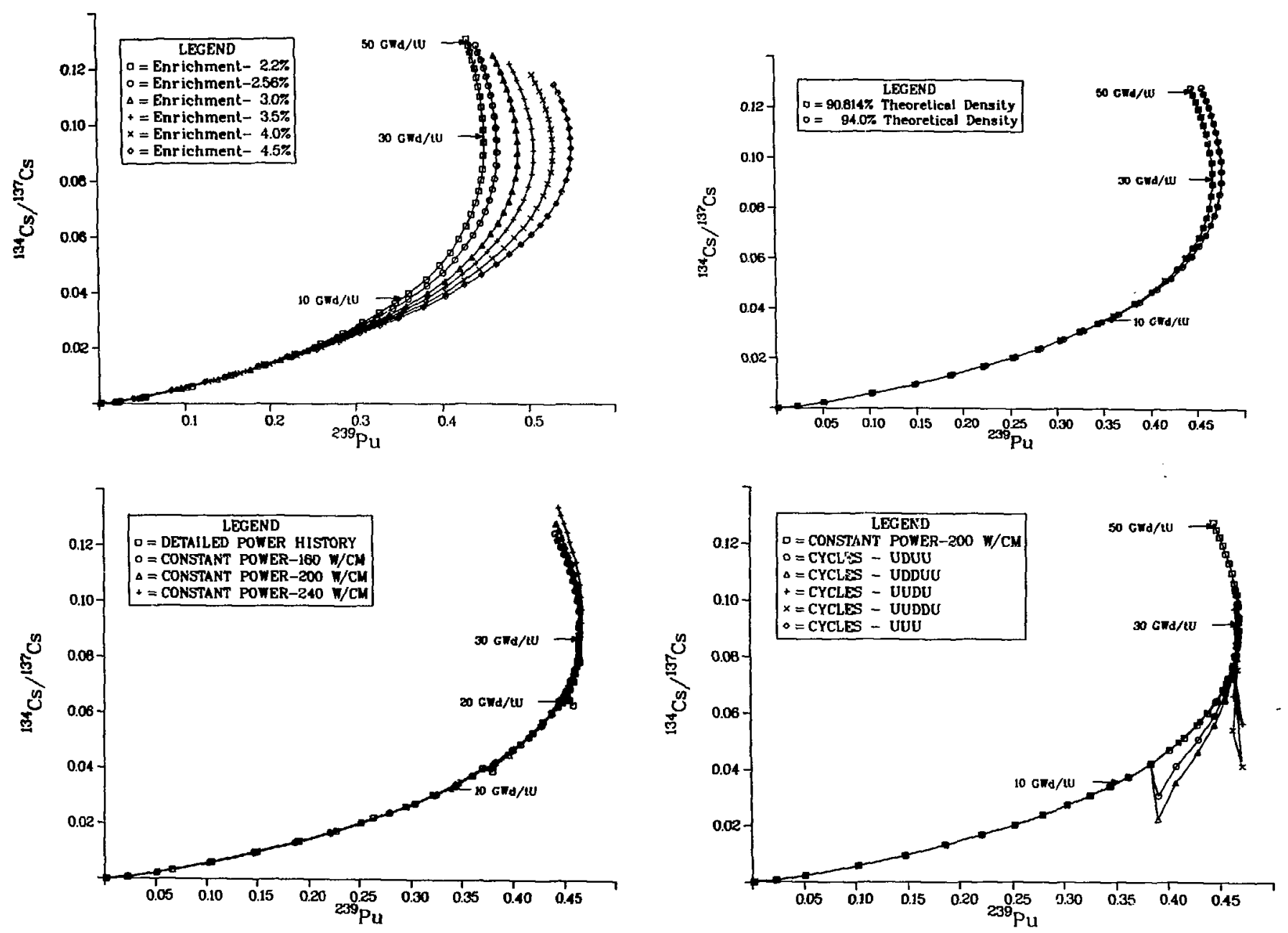

F19: $D-28$,

Dependence of correlation between $134 \mathrm{Cs} / 137 \mathrm{Cs}$ ratio and $239 \mathrm{Pu}$ on initial $235_{\mathrm{O}}$ enrichment, initlal $\mathrm{WO}_{2}$ mas density, power level, and irradiation history. 

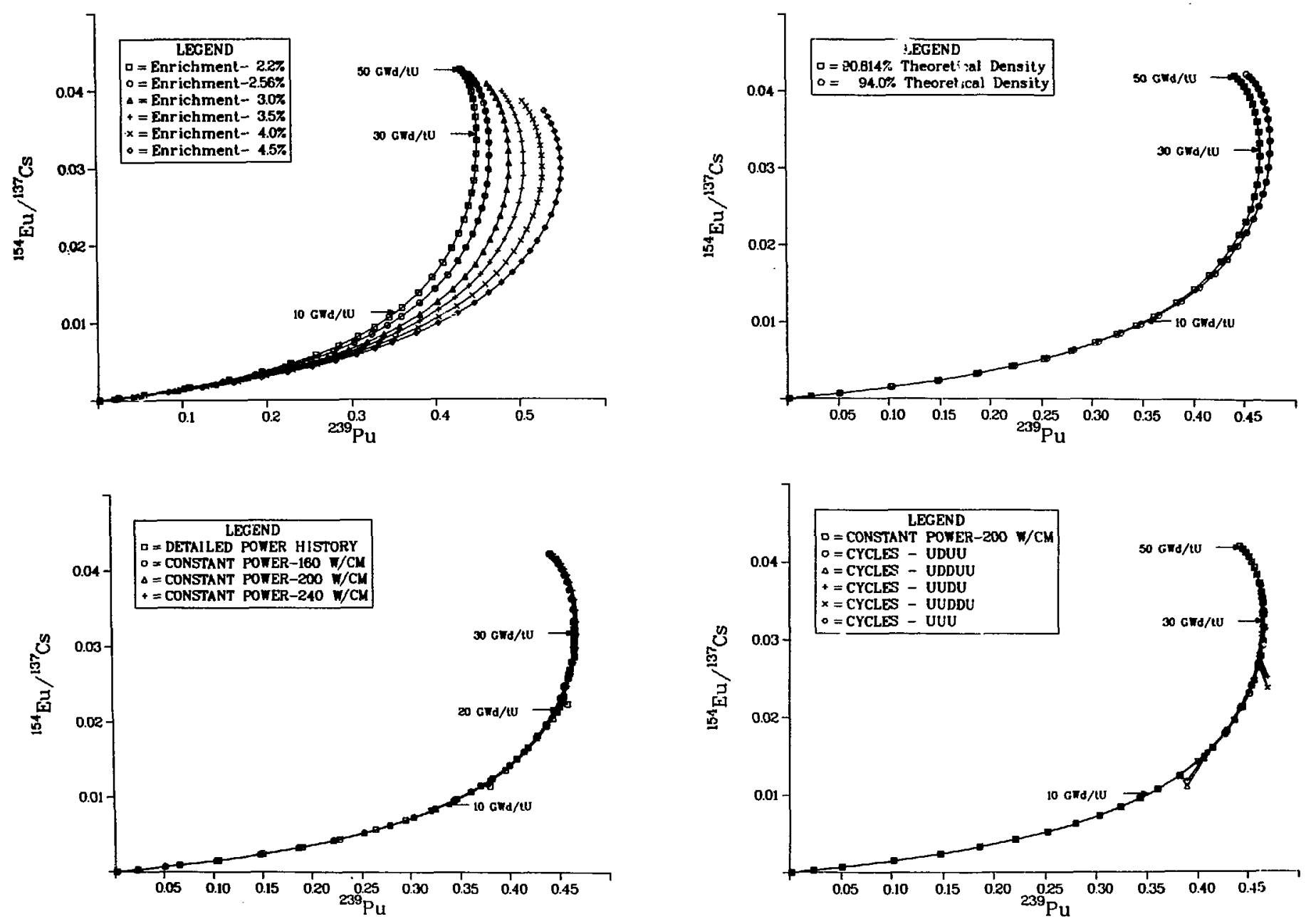

Fig. D-29.

Dependence of correlation between $154_{\mathrm{Fu}} /{ }^{137} \mathrm{Cs}$ ratio and $239 \mathrm{Pu}$ on initial $235 \mathrm{v}$ enrichment, initial $\mathrm{tO}_{2}$ mass density, power level, and irradiation history. 
61-day downtine between cycles (220 GWd/2U). Once the value of the ${ }^{134} \mathrm{Cs} /{ }^{137} \mathrm{Cs}$ ratio exceeds 0.065 , the corresponding quantity of ${ }^{239} \mathrm{Pu}$ does not change by more than 5s. This value of the ratio corresponds to a burnup range from 20 to $50 \mathrm{GNd} / \mathrm{tU}$. similar results are found for the ${ }^{154} \mathrm{Eu} /{ }^{137} \mathrm{Cs}$ isotope ratio, except that the threshold value of this ratio is 20.022 .

Figures $D-30$ and $D-31$ show the results of plotting these two isotope ratios as a function of the remaining fissile inventory $\left({ }^{235} \mathrm{U}+{ }^{239} \mathrm{Pu}\right.$ $+{ }^{241} \mathrm{Pu}$ ) in a typical FNR fuel assembly. The functional relationship is approximately linear in both cases. The ${ }^{134} \mathrm{Cs} /{ }^{137} \mathrm{Cs}$ ratio is affected by the 61-day downtime between cycles more than the ${ }^{154} \mathrm{Eu} /{ }^{137} \mathrm{Cg}$ ratio because the ${ }^{134} \mathrm{Cs}$ half-life is only $2.062 \mathrm{yr}$ compared to $8.6 \mathrm{yr}$ for ${ }^{154} \mathrm{Eu}$. These calculations indicate that information can be obtained from the isotope ratios ${ }^{134} \mathrm{Cs} /{ }^{137} \mathrm{Cs}$ and ${ }^{154} \mathrm{Eu} /{ }^{137} \mathrm{Cs}$ in addition to eatimates of exposure and cooling time. They also may correlate with the fissile inventory of spent-fuel assemblies.

\section{REFEREITES}

1. W. R. Cobb and W. J. Eich, wh New Cell Depletion Code," Trans, Am. Nucl. Soc. 24,442 (1976).
2. T. R. England, W. B. Wilson, and $H . G$. Stamatelaton, "Fiseion Product Data for Thermal Reactore, Part 2: Uaers' Manual for EPRICINDER Code and Data," Electric Power Reaearch Institute report EPRI NP-357, Part 2 (December 1976); also published as Los Alamos scientific Laboratory report Lil-6746-14S (December 1976).

3. T. R. England, W. B. Wilion, and $H . G$. Stamatelatos, "Firalon Froduct Data for Thermal Reactors, Part 1: A Data Set for EPRICINDER Using ENDF/B-IV," Electric Power Rssearch Institute report EPRI NP-356, Part 1 (Decenber 1976); also publinhed as Los nlamo. Scientific Laboratory report Lh-6745-HS (Decenber 1975).

4. A. A. Bauez, I. M. Lowry, J. S. Perrin, "Progress on Evaluating Strength and Ductility of Irradiated zircsloy During July Through September 1975," Battelle Mamorial Inatitute report BMI-1938 (1975), p. 16 .

5. G. Schulze, H. Witz, L. Kock, and R. Wellam, "Neutron Asmay Plus Isotopic Correlatione: A Method for Determing $P u$ and Burnup in Spent Fuel Assemblies," Proc. 2nd Annual symp. on Safeguards and Nucl. Mater. Manage., Edinburgh, Scotland, March 1980 (European Safeguard: Regearch and Development Assoctation, 1980), ESARDA 11, p. 396.

6. J. R. Phillips, J. K. Halbig, D. M. Lee, $S$. E. Beach, T. R. Bement, E. Dermendjlev, C. R. Hatcher, X. Kaleda, and E. G. Medina, "Mpplication of Nondestructive Gamma-Ray and Neutron Techniques for the Safeguarding of Irradiated Fuel Materials" Ios Alamos Scientific Iraboratory report LA-8212 (ISPO-77) (Hay 1980). 

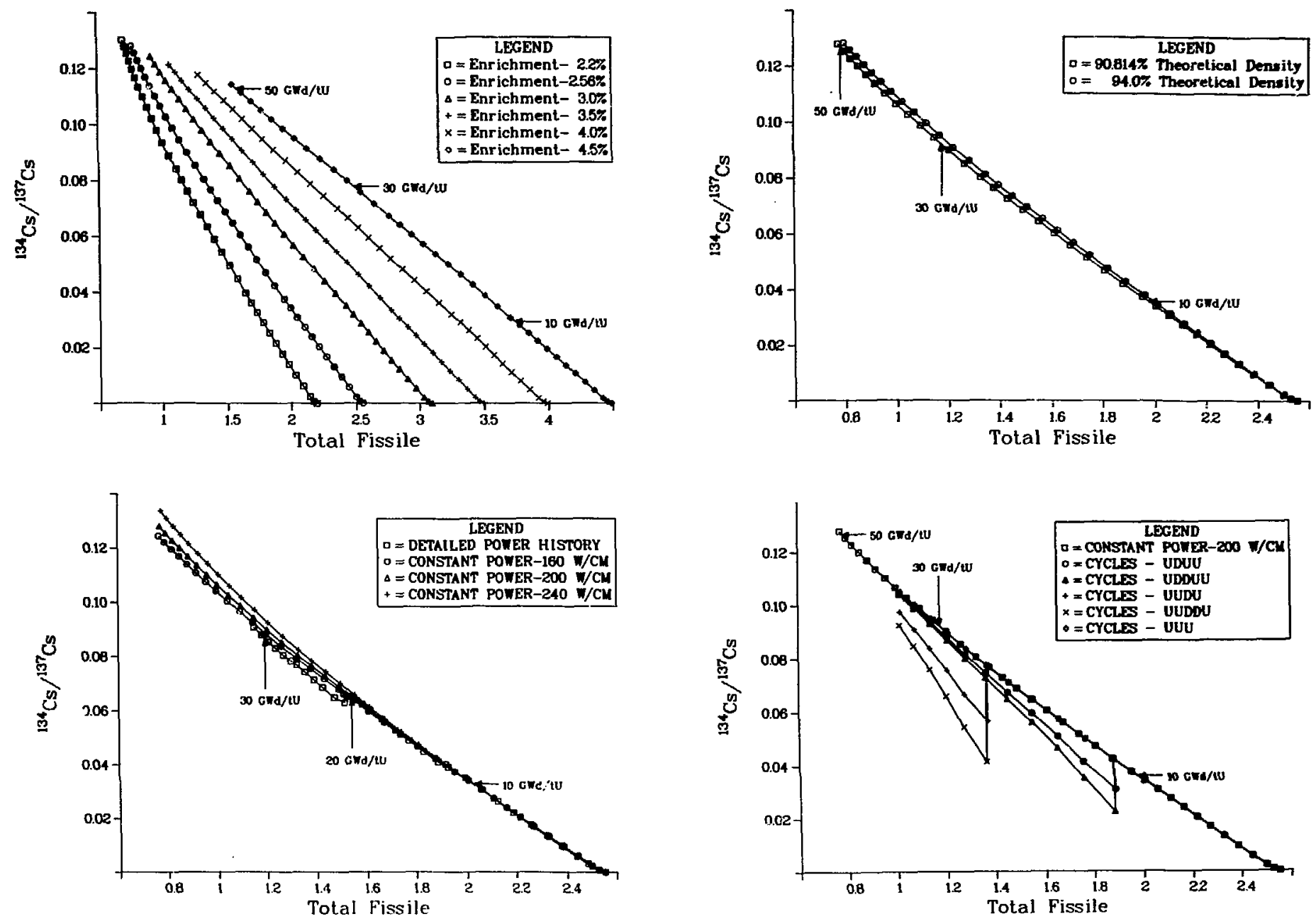

Fig, D-30.

Dependence of correlation between ${ }^{134} \mathrm{Cs} /{ }^{137} \mathrm{Cs}$ ratio and the concentration of total fissile material on initial $235 \mathrm{v}$ enrichment, initial $\mathrm{UO}_{2}$ mass density, power level, and irradiation history. 

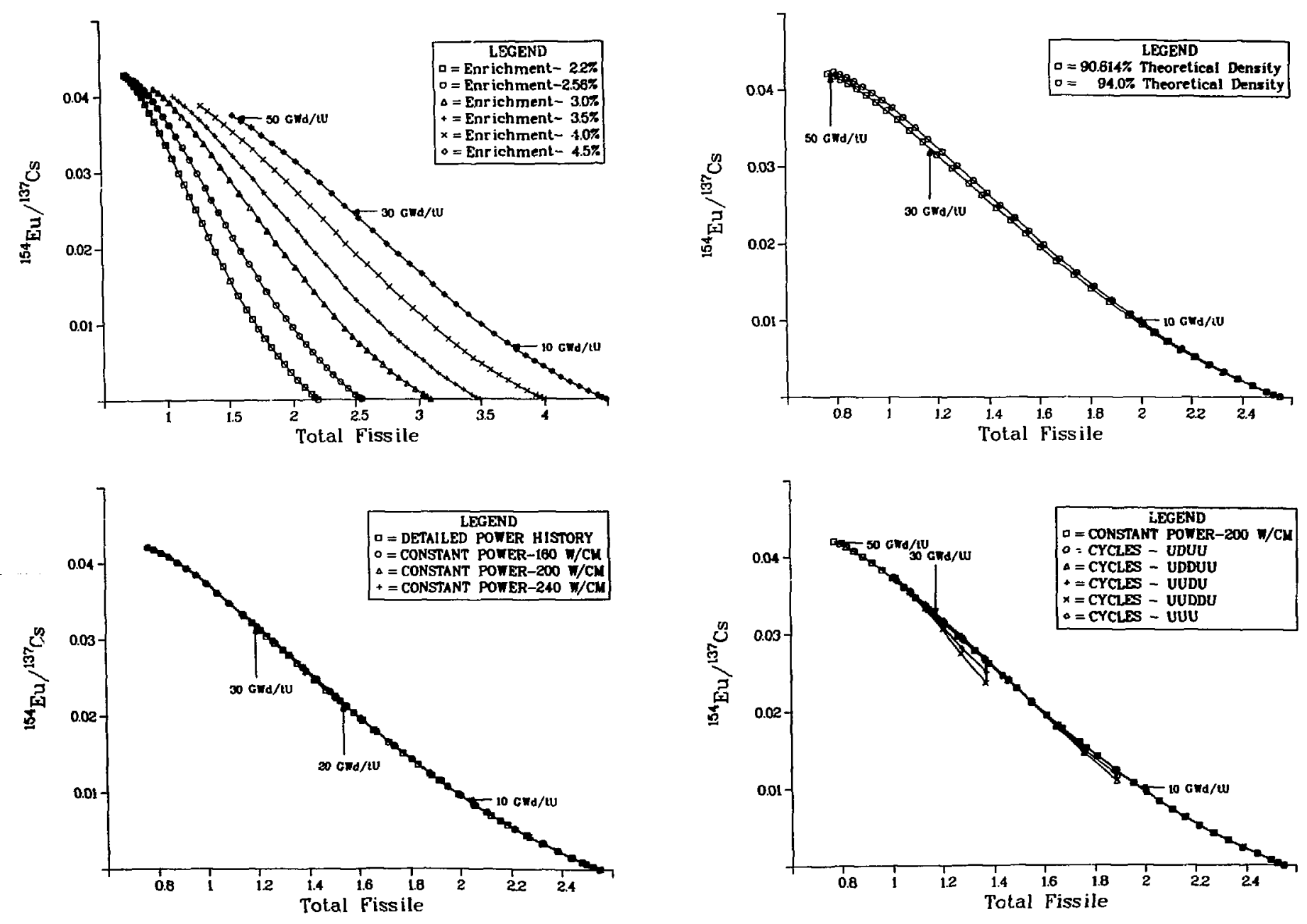

Dependence of correlation between $154_{\mathrm{Eu} /}{ }^{3} 7^{7} \mathrm{C}$ ratio and the concentration of total fissile material on initial $235 \mathrm{~V}$ enrichment, initial $\mathrm{VO}_{2}$ mass density, power level, and irradiation history. 


\section{APPENDIX $\mathbf{E}$}

PULSED-NEUTRON INTERROGATION TECHNIQUE FOR THE DETERMINATION OF THE FISSILE CONTENT OF SPENT-FUEL ASSEMBLIES

H. O. Menlove, G. E. Bosler, and G. W. Eccleston Safeguard: Assay Group Q-1

\section{INTRODUCTION}

A technique that uses pulsed-neutron sources to verify directly the uranium and plutonium fissile content. of spent light water reactor (LWR) fuel assemblies is under investigation. Because spent fuel 1. normally stored underwter in storige pools, the initial studiea are for fuel assemblies under several meters of water. This constraint. has the advantage of supplying the ohielding for the neutron interrogation source as well as the intense gama-ray dose from the fuel ansembly.

The fuel assemblies of most interest for the present study are irradiated pressurized-waterreactor (PWR) assemblies that contain both uranium and plutonium flssile component. Bolling-waterreactor (BHR) fuel asmemblies present a more conplex problem that will be addressed in future work. pulsed-neutron techniques ${ }^{1,2}$ have been used for several years in the uranium well-logging industry to ansay the quantity of uranium underground in exploration boreholes. Wort of the well-logging syatems have used senled-tube neutron generator to supply the Interrogation neutrons. Two bastc approaches have been uaed: one is to pulse the neutron source on and off and to count the Induced delayed fission neutrons when the interrogation wource fo off; the other is to count the Induced prompt fiasion neutrona hortly after each interrogation pulse. Both of these approaches are used to aseay the ${ }^{235} \mathrm{U}$ content of the ore. This logging procedure led to the development of compact and rugged neutron generatora that can be used in a relatively small borehol under several thousand feet of water. The enviroment in spent-fuel storage pool is mch more favorable than this.
Although the physical constraints for spentfuel measurements are not as severe as for welllogging, the radiation backgrounds are much higher. The gamma-ray doses could be up to $50000 \mathrm{R} / \mathrm{h}$ adjacent to fuel assemblies. There is also a neutron background that comes primarily from spontaneous fisaion and $(\alpha, n)$ reactions occurring within the fuel material. The spontaneous fiusion wources are the curium isotopes, ${ }^{242} \mathrm{Cm}$ and $244 \mathrm{~cm}$, and the even-numbered plutoniun isotopes. The $(\alpha, n)$ sources are primarily ${ }^{242} \mathrm{Cm}$ and ${ }^{241} \mathrm{Am}$. The intensity of this neutron background depends on the cooling time and level of exposure in the fuel ansembly, as shown in Fig. $z-1$. The source trength of background neutrons could be up to $10^{8} \mathrm{n} / \mathrm{s}$ for the entire fuel assembly. The measured neutron rates (Fig. E-I) are only for a small portion of the assembly.

Pulsed-reutron generators together with the prompt neutron signal have been used by Sandia National Laboratories, Albuquerque, ${ }^{3}$ for the measurement of finsile material in a portal monitor and by the Detection and Verification Group $0-2^{4}$ at Los Alanos for the ansay of small quantities of ${ }^{235} \mathrm{U}$ in large waste containers. Both of these myatems require large quantities of graphite and $\mathrm{CH}_{2}$ moderutor to extend the lifetimes of the thermal neutrons in the ayutem, thereby increaning the sensitivity for small quantitie of fisoile material.

A wodulated (or shuffler type) ${ }^{252}$ cf neutron source wa developed at Los Mlanos for the meanurement of ${ }^{235} \mathrm{v}$ content in bulk samplea. 5 More recently, this method was applied to spentfuel eloments and reproceseing waste canieter for 


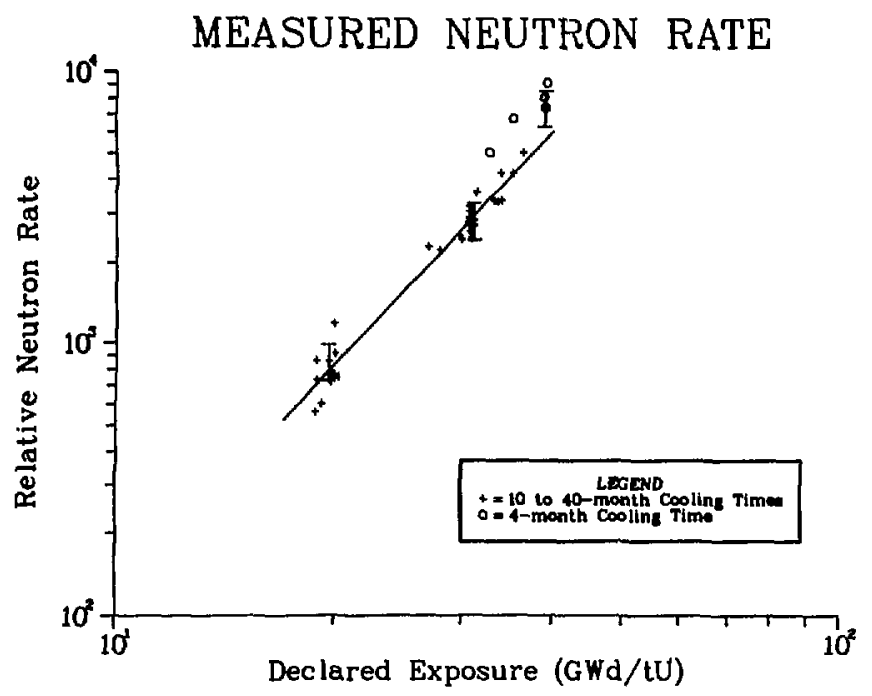

Fig. E-1.

Measured neutron-emisision rates vo declared burnup for 36 spent PWR assemblies at the zion Generating Station.

the Fluorinel and storage (FAST) $^{6}$ racility neutron 1nterrogator. In both cased, only the induced delayed flssion neutrons are measured to determine the ${ }^{235} \mathrm{u}$ content of high-enrichment uranium tuel.

II. PRINCIPLE OT THE TXCHNIQUE

Spent IWR fuel assemblies contain $\sim_{0.8-1.0}$ each by weight of fiasile urantum and plutonium. The straightforward assay approach of neutron interrogation and counting of the induced prompt or delayed fission neutrons is not ufficient to determine the plutonium content. During exposure in the resctor, the ${ }^{235} \mathrm{U}$ decreases, the plutonium increases, and the sum of the fiaslle components changes as 1lluvtrated in Fig. $5-2$. Thus, the measurement of the sum of the two components does not give the plutonium content.

One approach we are presently inventigating to assay the plutonium content is to masure both the prompt- and delayed-neutron responsen and then to use the prompt/delayed-neutron ratio to separate the two components. This is posalble becaune the delayed neutron fraction is roughly a factor of 2.6 higher for ${ }^{235} \mathrm{U}$ than ${ }^{239} \mathrm{Pu}$. Th1: same approach for esparating ${ }^{235} \mathrm{v}$ and ${ }^{239} \mathrm{Pu}$ in mixed-oxide fuel wa inventigated by us ${ }^{7}$ previously for fresh ErR fuel rods and by $Y$. Mateuda et a $1 .^{8}$ for irradiatad fuel pellets. For high burnup
Euel, the ${ }^{241} \mathrm{pu}$ contribution may interfere with the ability to meparate the ${ }^{235} \mathrm{U}$ and ${ }^{239} \mathrm{Pu}$ components.

A. Pulsed 14-MeV Neutron Generator crubek $^{l}$ has shown that with a pulned-neutron source, epithermal flux diemaway depends on the presence of fisuile material, that is, epithermal flux dies away much fauter in the absence of fiasile material. Theraal flux dis-away with and without tiseile material does not change as wuch as the epitherwal die-away. In adition, delayed neutrons from fission are present for times that are much longer than efther the epitheral or the thermal die-away times. Although crubek': reault: were for well-logging application, aldiar effect. are expected for pulsed-neutron interrogation of spent-fuel ansemblies. By selectively choosing measurement tiwes after a pulse, epitherwal die-away could be uned to verify figetle material premence and the fisalle composition could be deteralned from delayed neutrons. A possible drawback to such a system is the hlgh background of spontaneous fiesion and $(\alpha, n)$ neutrons in spentfuel ansemblies.

Time-dependent calculational studies are being performed to deternine the fearibility and applicability of an active opent-funl aseay oystem. These calculations use the Ios Alamos Nonte Carlo code Mcip. 9 In the current nodel, mutrone from 


\section{CALCULATIONALLY ESTIMATED QUANTITIES \\ PWR SENSITIVITY SERIES -- CASE A-2}

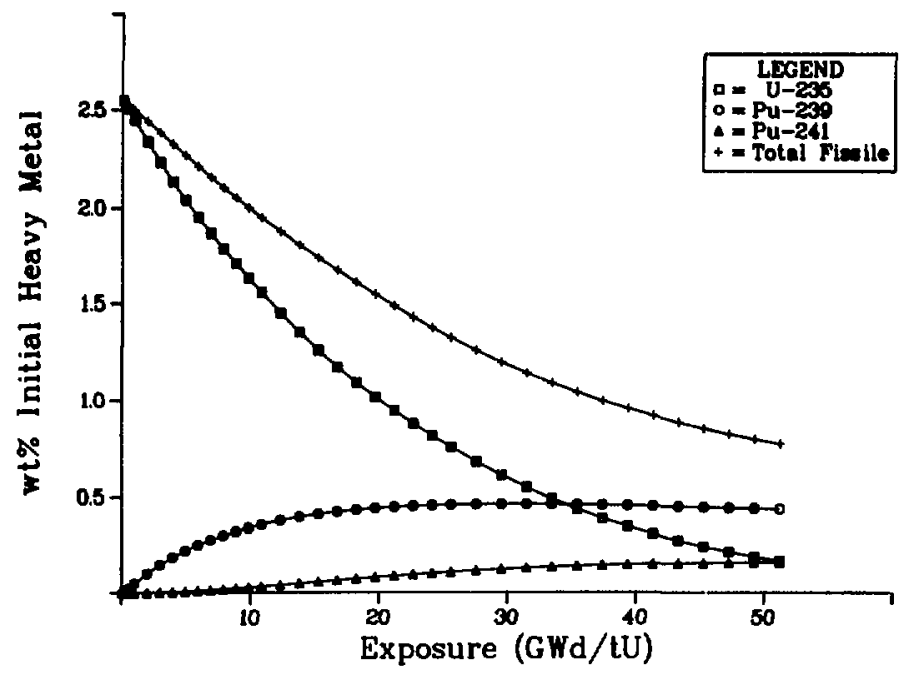

Fig. E-2.

Calculation of weight per cent of $235 \mathrm{v}, 239 \mathrm{Pu}$, and $241_{\mathrm{Pu}}$ as a function of burnup.

a 14-MeV (D,T) source pulsed for 15 us are introduced into a typical 15 by 15 PWR spent-fuel ascembly. A f1usion chamber surrounded by $25 \mathrm{~cm}$ of polyethylene and a thin layer of cadrium forms the epithermal neutron detector. The cadnium reduces the detector reuponse to low-energy neutrons coning from the assembly and the $(D, T)$ source. The entire system is surrounded by water to inulate measurement procedures in spent-fuel storage ponds. Fuel-water heterogeneity effects are accounted for by actually modeling fuel pins in the assembly.

A diagram showing the initial geometric metup for the Monte Carlo calculations is shown in Fig. E-3. A version of MCNP, which was developed for tracking delayed noutrone, is beling adapted for this study. Previously only the delayed neutrons arising from fissions produced by fast incident neutrons were considered. The modified version of the code considers delayed fission neutrons arising from either fast or thermal neutrons. This is 1mportant because most of the source neutrons will be thermalized in the water environment before causing fiestion. in the spent fuel.

Time diecrimination between the 14-HeV source neutrons, the prompt fiesion neutrons, and the delayed fisetion neutrons in poratble because the

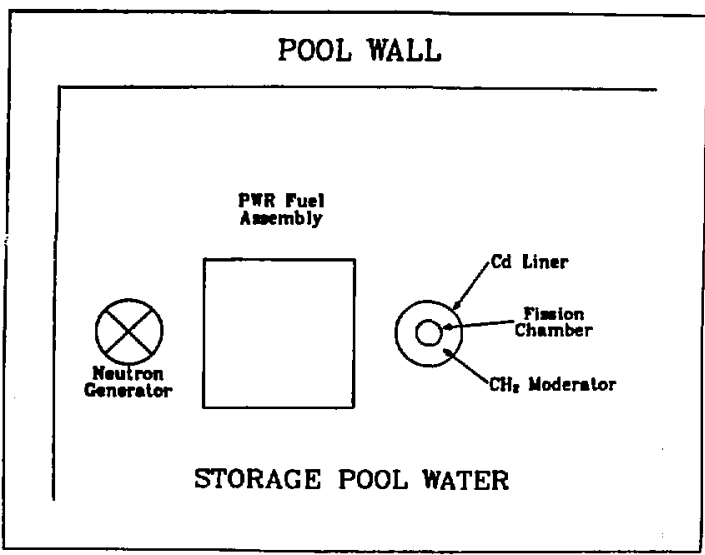

Fig. E-3.

Geometric configuration of the active neutron interrogation source, the PWR assembly, and the detector for counting prompt and delayed neutrons. 
-lowing down time of noutrons in water from $14 \mathrm{HoV}$ to epicadnium energy ( $\mathrm{u} .3 \mathrm{eV}$ ) takss only a fow microseconds, whereas the thermal neutrons have a lifetime of $2200 \mathrm{us}$ in water. Figure $\mathrm{J}-4$ show the time sequence for a repetitively pulaed ayatem. During the time period from a few tens of microseconds to a few hundred microseconds, the prompt fission neutron are counted. The $14 \mathrm{MeV}$ neutrong produced by the generator are thermalized and induce fission in the flosile material. For the detector shown in Fig. E-3, the cadmium Iiner prevents most of the thermalized source neutrons from reaching the detector. The induced fission reactions are closer to the detector, and a significant fraction of the prompt fiscion neutrons retain sufficient energy to pass through the cadmium barrier and reach the detector. The delayed-neutron time gate is opened 21500 us after the generator pulse. The neutrons in this time interval are from induced fissions corresponding to many prior pulses. The intensity of the delayedneutron signal slowly huilds up and reaches equiIibrium after a few minutes because the longestlived delayed-neutron precursor has a half-life of 255 s.

B. Modulated ${ }^{252}$ Cr Neutron Source

As an alternative to the 14-MeV neutron generator, a modulated ${ }^{252}$ cf neutron source can be used for the same application. The induced prompt fission neutrons are counted while the ${ }^{252} \mathrm{Cf}$ is in the near vicinity of the fuel assembity. The ${ }^{252}$ Cf source then is moved rapidly away from the fuel asaembly and detector and the delayed neutrons are counted. To obtain sufficient counting atatistics, the source is repetitively transterred back and forth between the sanple and its shielded position, as is done in the ${ }^{252}$ cf shuffler ays$\operatorname{tem}^{7}$ described previously. Figure $\mathbf{E - 5}$ show: a achematic diagram of the irradiation and counting cycle. The irradiation \pm ime of $\eta_{10} \mathrm{~s}$ is considerably longer than the delayed-neutron counting time $\left(n_{3} s\right)$ to improve the oignal-to-background ratio. Again, a high neutron background is expected from the spent fuel.

In addition to the background neutrons from the spent fuel, there are background neutrons from the ${ }^{252}$ cf source during the prompt-neutron counting interval, as shown in Fig. E-5. The number of these source neutrons reaching the detector can be reduced by absorption in a cadmium leeve around the detector, as shown in Fig. E-2. Similar to the pulsed-neutron generator approach, the induced Eission neutrons are closer to the detector than the californtum source, and thus a higher fraction of these signal neutrons are above the cadmium energy cutoff and reach the detector.

c. Separations of Fissile Urantum and Plutonium Content:

The delayed-neutron fate per source neutron is roughly the same for both the pulaed $14-\mathrm{HeV}$ neutron source and the modulated $252 \mathrm{cr}$ source. However, a wource intenulty of $10^{9}-10^{10} \mathrm{n} / \mathrm{a}$ can be obtained more readily with a ${ }^{252} \mathrm{Cf}$ source ( $\nu_{1} \mathrm{mg}$ ) than with currently available sealed-tube neutron generators.

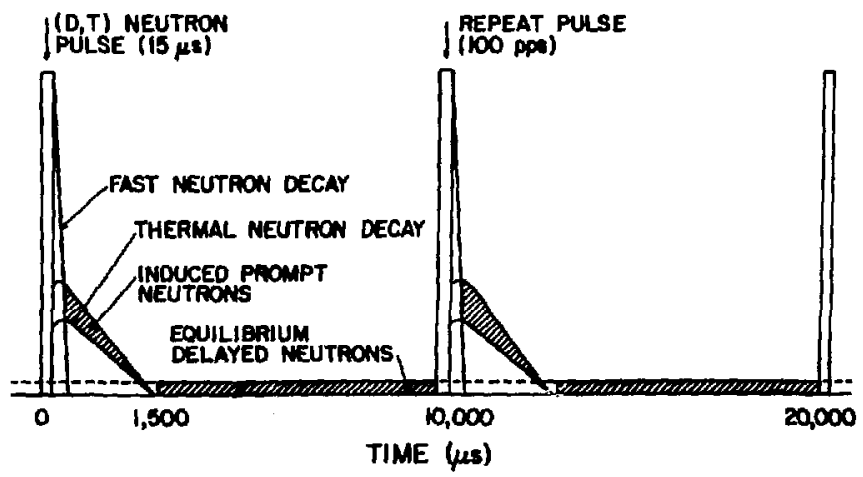

Fig, E-4.

Active neutron irradiation and counting cycle for a puled-neutron generator using both prompt- and delayed-neutron counting. 


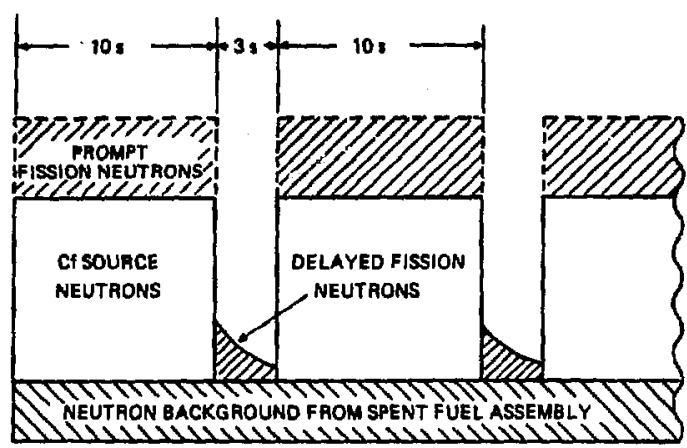

TIME (s)

Fig. E-5.

Active neutron irradiation and counting cycle for a modulated $252 \mathrm{cf}$ neutron source using both prompt- and delayed-neutron counting.

Table E-I shows the delayed fraction and discrimination ratio ${ }^{10}$ for the principal fissile components. The ${ }^{235} \mathrm{U}$ has considerably more delayed neutrons per fission resulting in a discrimination ratio of 2.6 relative to ${ }^{239} \mathrm{Pu}$ for a twocomponent linear ayatem. Because the ${ }^{241} \mathrm{Pu}$ has a delayed-neutron fraction that is very similar to ${ }^{235} \mathrm{U}$, it w11l tend to wash out the discrimination factor. We propose to circumvent this problem through iterative techniques, using calculated isotopic correlations. That is, in the first estimate of the ${ }^{235} \mathrm{v}$ and ${ }^{239} \mathrm{pu}$ comporents, the ${ }^{241} \mathrm{Pu}$ contribution would be neglected. The estiuated ${ }^{235} \mathrm{~d}$ and ${ }^{239} \mathrm{Pu}$ ratios would then be used to predict the ${ }^{241}$ Pu fraction using 1sotope correlations. The inftial data would then be corrected for the ${ }^{241} \mathrm{Pu}$ contribution and the ${ }^{235} \mathrm{v} /$ ${ }^{239}$ Pu ratio would be re-estimated. These more accurate values would then be used to predict a better value for the ${ }^{241}$ pu fraction to carrect the Initial values, and so forth until convergence. Because the ${ }^{241} \mathrm{Pu}$ is a relatively 11 fraction of the measured response, we expect that the error introduced by this correction procedure will be mall.

Modifications have been made in the Monte carlo code MCNP so that calculatione can be performed to determine aignal-to-background ratios for the delayed neutrons, optimal source-detector
TABLE E-I

DELAYEV NEUTRON FRACTIONS

\begin{tabular}{|c|c|c|c|}
\hline Isotope & $\begin{array}{c}\text { Fission } \\
\text { Cross Section } \\
\text { (b) } \\
\end{array}$ & $\begin{array}{c}\text { Discrimination } \\
\text { Ratio } \\
\end{array}$ & $\begin{array}{l}\text { Delayed- } \\
\text { Neutron } \\
\text { Fraction }\end{array}$ \\
\hline $235 \mathrm{U}$ & 584 & - & 0.0168 \\
\hline${ }^{239} \mathrm{Fu}$ & 742 & 2.6 & 0.0061 \\
\hline $241_{P u}$ & 1010 & - & 0.0154 \\
\hline
\end{tabular}

The discrimination ratio 18 defined in Ref. 10 for a two-component system where $235 \mathrm{U}$ is one of the components. For $241_{\mathrm{Pu}}$, the discrinination ratio in not applicable.

bihe delayed-neutron fraction is the yield of delayed neutrons per fission event.

conflgurations, sensitivity to changes in the plutonium and uranium isotopic compositions, and sensitivity to the removal of individual fuel plns. These calculations will be performed as part of our program to evaluate active neutron techniques for the verification of spent-fuel assemblies.

\section{REPERENCES}

1. Jan A. Crubek, "Pulmed Neutron Method for Uranium Well Logging," Geophysica 37(1), 160173 (February 1972).

2. H. M. Bivens, G. W. 5nith, and Dal H. Jenven, "Pulsed Neutron Uraniun Borehole Logging with Prompt Fission Neutrons," in Proceedinge of the Fourth Conference on the Scientific and Industrial Applications of Small Accelerators, J. I. Duggan and J. A. Martin, Eda., North Texas State Univ., Oct. 27-29, 1976 (US Energy Reeearch and Development Administration 1977) p. 441 .

3. G. W. Sulth and L. G. Rice, III, "An Active Neutron Technique for Datecting Attempted Special Nuclear Material Diveraion," In Measurenent Technology for safeguards and Materials Control, T. R. Canada and B. S. Carpenter, Eds.., National Bureau of Standards Special Publication 582 (Iune 1980), pp. 372389.

4. W. E. Kunz, J. D. Atencio, and J. T. Caldwell, "Pulsed Neutron Waste Monitor," in "Nuclear Sateguarie Research and Developant Program Statu. Report, January-herch 1980," LOE Mlanos scientific Laboratory report LA-8373-PR (1980), pp. 28-29. 
5. H. O. Henlove and T. H. Crane, "A $252 \mathrm{Cf}$ Based Bondestructive Assay Sygtem for Fissile Material," Nucl. Instrum. and Methods 152, 549-557 (1978).

6. G. W. Jccleaton, H. O. Henlove, and M. W. Echo, "A Measurement System for High Enriched Spent Fuel Assemblies and Naste Solide," Nucl. Mater. Manage, VIII, 344-355 (1979).

7. G. Robert Keepln, "Nuclear Analysis Research and Developenent, Program Status Report" Los Alamos Scientiflc Laboratory report LA-5431-PR (November 1973), pp. 4-5.
8. Y. Matsuda, T. Tamura, T. Murata, "Nondestructive Assay of Uranium-235 and Plutoniun-239 in Nuclear Reactor Fuel," in Nuclear Safeguards Technology 1978, Proc. Symp., Vienna, October 2-6, 1978 (International Atomic Energy Agency, Vienna, 1979), IAEA-SM-231/66, Vol. II, IAEA-SM-231/30.

9. w. L. Thompson, "MCNP - A General Monte Carlo Code for Neutron and Photon Transport," Los Alamos Scientific Laboratory report $\mathbf{H A}-7396-\mathrm{H}$ (July 1978).

10. H. O. Menlove, R. H. Augustaon, and Darryl B. Smith, "A Multi-Spectra Neutron Irradiation Techntque for the Nondestructive Ansay of Elssionable Materials," Nucl. Technol. 10, 366 (1971). 
APPENDIX F

EXPERIMENTAI PROGRAM AT LOS ALAMOS

G. W. Eccleston and M. R. Baker Safeguarde Assay Group Q-1

Design of the active and passive neutron portions of the pent-fuel verification and assay system is being accomplished uaing both experinents and calculations. This appendix describes the experimental facilities, the avallable materials, and the experiments in progress at Los Alamos to complete the research necesaary to achinve the specified measureaent goals. The experimental progran at Los Mlamos is limited to handling unirradiated fuel assemblies. Gamma-ray and ionchamber measurements, therefore, have to be obtained with field experiments and are discussed in App. B. Passive and active neutron measurements can be performed on unirradiated assemblieg by using neutron sources to induce fissions in the fuel. The primary purpose of the experimental work is to develop a design permitting neutron measurements on light-water-reactor (LWR) fuel asemblies. The neutron measurements will be used to determine the burnup and the total effective fisslie content in irradiated fuel assemblies.

\section{EXPERIMXNTAI FACILITIES AND EQUIPUINT}

The experimental measurementa are being performed at the Safeguards Hot Cell Facility at Ios Mlamos. An exterior view of the facility is shown in Fig. F-1. The hot cell contains three shielded viewport. with remote anipulators at two of the windows. Additional remote viewing of the cell interior is provided with two television units that have pan, tilt, zoom, and focus controle. Personnel entry to the cell ia through an intermediate room and then pant an accese port that can be eealed with a 1.22-e-thick concrete door. Contanlnated materials are not processed in this hot cell, and 1te enfor advantages are the capability for handling radiation sources and providing a shield from other experiments outside the cell. Intense radioactive sources stored in large shield containers are moved into the cell through an overhead access port. This port, sealed by a 1.22-m-diam by 1.22-m-thick concrete plug, can be opened by lifting the plug with a 50-ton-capacity crane.

The interior of the hot cell, shown in Fig. F-2, is $4 \mathrm{~m}$ deep, $15 \mathrm{~m}$ wide, and $5 \mathrm{~m}$ tall. The crane in the cell permits an overhead working clearance of $2.7 \mathrm{~m}$ and has a lifting capacity of 5 tons. Crane operations can be controlled from Inside and outside the cell. Access portg at each shield window permit instrument cabling between the cell and exterior equipment. Isolated power routed inside and outside the cell limits electrical interference from outside sources and is hilelded to reduce ground loop noise. The size and features of the hot cell enable a variety of experiments to be carried out simultaneously using the three shield windows.

Two experimental stations (Fig. F-l) are located at the two shield windows with the remote manipulators. One station has a Canberra Series 80 Single Parameter Multichannel Analyzer (MCA), and the other has a Canberra Multiparameter MCA. Both analyzers are Interfaced to Digital Equipment Corporation (DEC) LSI-11 microcomputers. Analyzer data can be collected manually using the Canberra keyboard or remotely with software executed by the computers. Mass storage for computer programs and data is provided by 5-megabyte hard disks. Dualdensity floppy diskette are used for archival atorage and to transfer information between computers. Detector ignals collected from experiments In the hot cell are routed to nuclear instrument modules (NIM) at the masurement stations outaide the cell. A complete set of NIM 1s avallable to process detector signal.. These eignala can be 


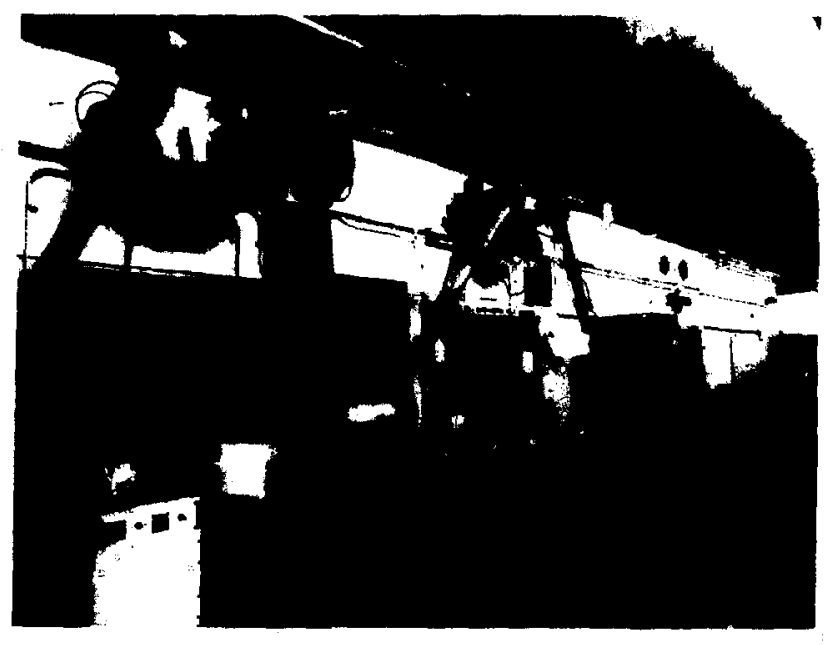

Fig. F-l. Hot cell exterior view.

Fig. F-2. Hot cell interior view.

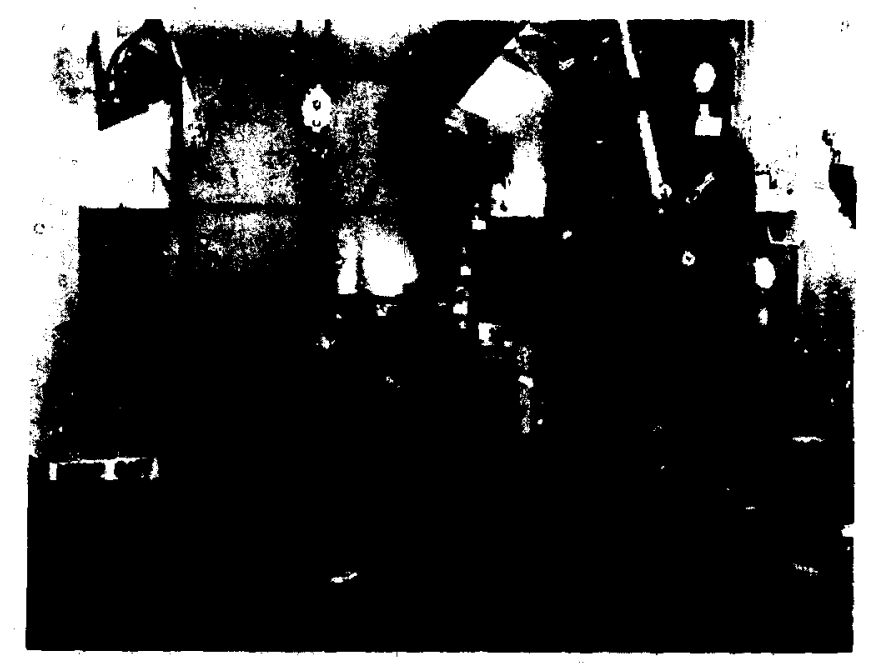

routed to the analyzers or directly to the computers using acaler interface board that resides in the computer backplane. This scaler consists of 6 channels, each with a 24-bit count capacity. Additional interfaces can be adied to the computer to provide increased control and monitoring of experiments.

Design constraints for spent-fuel measurements require that data be collected undewater. To enable underwater measurements at the hot-cell facilities, two tanks were constructed to permit fuel assemblies to be immersed in water. One tank, a cylindrical barrel $140 \mathrm{~cm}$ high and $50 \mathrm{~cm}$ in dian, enables a large volume of water to surround a fuel assembly. The other tank, alıo $140 \mathrm{~cm}$ high, is square with an Inside dimension of $22.2 \mathrm{~cm}$, providing a tight fit for presaurized-water-reactor (PWR) fuel assemblies. Thi tank is surrounded by a table permitting a variety of material and detectors to be eastly locited around the fuel for measurements. 
A variety of detector and neutron mourcen are available for experimental measurements, including ${ }^{3}$ he, ${ }^{10}$, and fiesion chawber detectore. Water-tight polyethylene cylinders have been dealgned to houe the detectors for underwater meanurements. Imotopic neutron cources available for mesesurements Include Im-Li, Pu-Ba, Ra-Be, and $252 \mathrm{ct}$, in adaition to $124 \mathrm{sb}-\mathrm{Be}$ photoneutron source. The californiu sources are enall in size and have a conventent half-life and a large range of neutron yields. Californiun sources currently avallable for mearemente have yields ranging from $10^{4}$ to $10^{8} \mathrm{n} / \mathrm{a}$ and way be obtalned with yleIds to $10^{10} \mathrm{n} / \mathrm{s}$. These sources have ben calibrated by the National. Bureau of standirds and thus are ueeful for normilizing experimental data to counte per source neutron for comparison with Monte Carlo calculations.

\section{INITIRE CODDE VAIDATION EXPERIMATS}

leutron wasuremente on apent-fuel asemblies require countere capable of operating in large neutron fields $\left(10^{10} \mathrm{n} / \mathrm{s}\right)$ inile subject to intence gawn does rates $(50000 \mathrm{M} / \mathrm{h})$. $\mathrm{h}$ few neutron detector are capable of woeting these requirenents, and erong them fiasion chabera offer some diutinct adventages. Fisuion chambers require 11ttle or no gumeray shielding and are capable of datecting individunl neutrons in the presence of an incident gemen-ray flux of $10^{6} \mathrm{w} / \mathrm{h}$. They have low dection efficiency enbling noutron counting to be perforned with ainimal deadtie efecte when expored to large neutron fields. Nsearch and avelopont experiente portaining to apent-fue; measuremente incorporate fiesion chambere for both parsire and active neutron seasurenentis.

The finsion chambera are supplied according to the specificatione listed in Table F-I. Chambers with varying dimeneions way be ordered. Uraniu contings on the tube wall wry hive thicknesere up to $2 \mathrm{mg} / \mathrm{cm}^{2}$. The detectora currently in uee contein $143 \mathrm{gg}$ of $\mathrm{UO}_{2}$ enriched to 93.2 wts ${ }^{235} \mathrm{u}$, corremponding to a $1 \mathrm{mg} / \mathrm{cm}^{2}$ wall coating.
TALLF F-I

GPFCIICATIONS FOR MATCHED 2.54-CH-DIM 235 U PROFORTIONAI COUTrER

1. 12.7-cm ative length, 2.54-cm diant overall length not to exceed $36.5 \mathrm{~cm}$.

2. Optiman operating voltage mut be lene than $1000 \mathrm{~V}$.

3. Uraniun coating on tube wall wust be between 1 and $2 \mathrm{mg} / \mathrm{cm}^{2}$. Total quant1ty of $\mathrm{U}-235$ sha1l be $143 \mathrm{mg}+108$. Uranfun shall contain 935 or more $235 \mathrm{~J}$ by 1 sotope wight. All detector: ahall be watched for total uraniun content within 58.

4. Tube walle must be made of $1100 \mathrm{Al}$.

5. All detectore muet be equipped with standard fomale HN connectore mouted axially at one end of the detector in a maner euch that the detector and connector form a mochanically and electrically wound unit.

6. Detectore must be capable of detecting individual neutronc (counting mode) in the presence of an incident gama flux of $10^{6} \mathrm{R} / \mathrm{h}$.

7. Detectors shall be able to operate at $200^{\circ} \mathrm{C}$ and axhibit no more than 10 decrease in senitfvity for a $3 \times 10^{20}$ thermal neutron Eluence.

8. The maximum in the pulae-height diatribution for all detectore muat lie within 58 of the average of the peake for all detectors operated at the same optimun high voltage.

9. To neet the above specifications, the vendor is expected to perform the necessary calculatione and teats to arrive at the gat mixture, wall coating to give cufficient multiplication, stopping power, and minimum rite time.

Design of a spent-fuel assay oystem depends on understanding the neutronics of buckground neutrons (primarily ppontaneous fission from ${ }^{242} \mathrm{~cm}$ and ${ }^{244} \mathrm{Cm}$ and neutrons from fission produced by an external neutron-interrogation aource. Heasureante that enable the neutronice to be ntudied are afficult to obtain in a leboratory environment where the acturl epent-fuel assemblies cannot be handied. computer calculatione using Fonte carlo and Diacrete Ordinates codes enable paranetric data to be obtained to enhance the neutronice etudien ueing laboratory masurements. Ixperiente are possible on unirradiated fuel asemblies that 
represent various atages of burnup. These experiments are conducted using appropriate combinations of cold fuel roda containing aither plutonium or uranium to simulate various burnups. Calculations that sinulate the experimental geometries are compared with the mousured data to check the validity of the computer modele. In addition, the calculations, once validated, provide information on the aultability of the experimental mock-up amsemblies for providing derign data that correspond to actual opent-fuel assembliea.

To simulate the underwater enviroment for experiments, a large water-tight aluminum barrel, $50 \mathrm{~cm}$ in diam by $140 \mathrm{~cm}(4.5 \mathrm{ft}) \mathrm{high}$, was constructed. Experiments using this barrel were conpleted to provide initial validation of Nonte Carlo calculations. The experiments consiated of filling the barrel with water and positioning a ${ }^{252} \mathrm{CF}$ source and fiasion chamber at the midplane of the barrel. Fission chamber count rates were obtained for a series of mource-detector meparations. The 252 ce source produced $4.51 \times 10^{5} \mathrm{n} / \mathrm{s} \quad( \pm 1.22 \mathrm{t}$ on $12 / 1 / 80$ ) at the time of the experiment. The Monte Carlo code tallies events on a per-sourceneutron basis, wo that the measured count rates had to be converted to cunts per source neutron for direct comparison with calculations.

Wonte Carlo calculations were performed uning a model geonetry that described the experimental source-detector configuration. The fianion chamber was simplified in the calculations by modeling the $\mathrm{NO}_{2}$ wall coating as a gas uniformly distributed throughout the detector. The vo gal density in the fission chamber was computed to be $2.22 \times 10^{-3}$ $\mathrm{g} / \mathrm{cm}^{3}$, corremponding to $5.0 \times 10^{18} \mathrm{vo}_{2}$ molecules $/ \mathrm{cm}^{3}$ or $1.5 \times 10^{19}$ ators $/ \mathrm{cm}^{3}$.

A serles of calculations was performed for different detector-nource meparations corresponding to the experimental masurements. The neutron source in the conputer rune was modeled as a point, isotropic neutron eutter with a fiston-energyspectrun dietribution. Continuous energy cross ection aupplied with the Wonte Carlo code were used for all materials. Interactions of neutron. with water wre treated using the thermal scattering model. This model is generally referred to af $s(\alpha, \beta)$ and provides a complete representetion of thermal neutron wattering by molecules and crystalline solida. Fission events in the detector were determined as fimsions per source neutron. The calculational data are plotted an the uppar curve of Fig. F-3.

The experimental and calculational data of Fig. F-3 are listed in Table F-II. The data are independent and no normalization factor han baen applied between the experiments and calculations. The experimental measurements (counts/neutron) are systematically smaller by 7-50t compared to the calculations. The code calculates fiseions per source neutron and not counts. The measured count rate for a fiasion chamber with a $1 \mathrm{mg} / \mathrm{cm}^{2} \mathrm{No}_{2}$ coating may require a correctional increase of up to 25t to obtain the fission rate. This correction Is required with detectors that have a thick wall coating. A certain percentage of the heavy mast fragments produced in fission will lose enough energy escaping the $\mathrm{JO}_{2}$ to be below the alpha threshold, thus preventing the register of a fission count.

The percentage difference between the calculational and experimental data increases as the distance between the source and detector decreases. The calculated thermal and epithermal neutron flux in water from a fiesion spectrum as a function of distance from the source is shown in Fig. F-4. The energy spectrum from a fission source in water reaching a detector is essentially all epicadnium $(>0.25 \mathrm{eV})$ for distances of $5 \mathrm{~cm}$ or less between the source and detector. Resonance velf-shielding effect: that depend on neutron energy and approximations in modeling the detector as filled with $\mathrm{DO}_{2}$ gae may account, at least in part, for the Increasing difference observed between experiment and calculation for small source-detector meparation.

Active and passive neutron meaturementa on epent-fuel assemblies ma meanure either total or epicadaiu counts. Epicadaitu evente are obtained by wrapping the countert in cadmium. Ganarally, to increase detection efficiency for epicadulu events, the counters are encased in a polyathylone leeve that is wrapped in cadnium. Deteraination of the effect of cadive on a fisalon source and a 


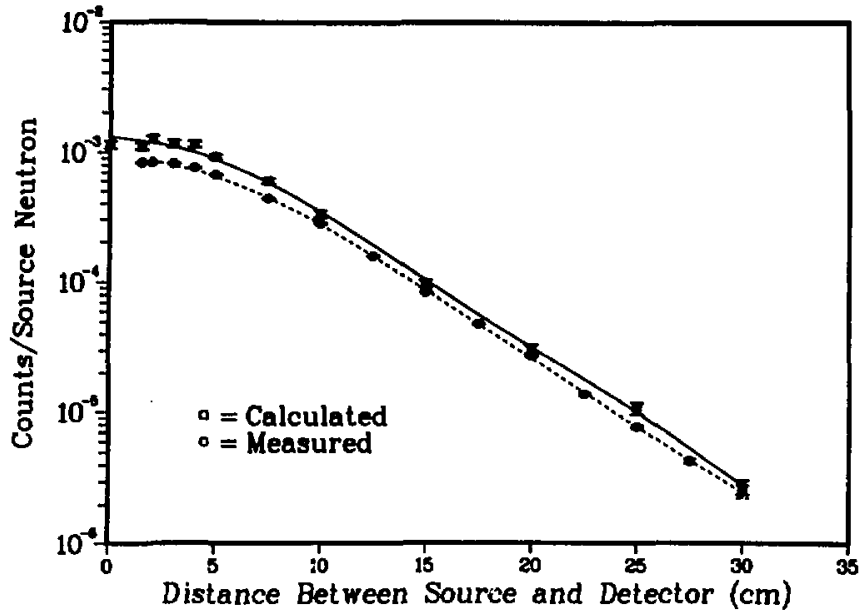

TABLE F-II

COMPARISON BETNEEN EXPERIMENTAL AND CALCULATIONAL RESPONSES TO A $252 \mathrm{CE}$ SOURCE FOR A FISSION CHAMBER IN WATER

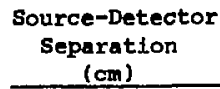

0

1.5

2.0

3.0

4.0

5.0

7.5

10.0

12.5

15.0

17.5

20.0

22.5

25.0

27.5

30.0

\section{Experiment}

(counts)

source neutron)

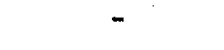

B.34-4 $\pm 2.43-5$

8.37-4 $\pm 1.05-5$

8.23-4 $\pm 1.03-5$

$7.61-4 \pm 9.58-6$

$6.77-4 \pm 8.77-6$

$4 \cdot 40-4 \pm 6 \cdot 10-6$

$2.79-4 \pm 4.53-6$

$1 \cdot 57-4 \pm 2 \cdot 27-6$

8.41-5 $\pm 1.41-6$

4.86-5 $\pm 8.52-7$

2.73-5 $\pm 6 \cdot 77-7$

$1.37-5 \pm 3.47-7$

7.72-6 $\pm 1.91-7$

$4.35-6 \pm 1.05-7$

2.62-6 $\pm 1.19-7$
Calculation

(ftssions) source neutron)

$1.142-3 \pm 7.526-5^{a}$

$1.112-3 \pm 6.272-5$

$1.261-3 \pm 7.780-5$

$1.158-3 \pm 7.133-5$

$1.147-3 \pm 6 \cdot 148-5$

$9.268-4 \pm 3.679-5$

$6.020-4 \pm 2.703-5$

$3.322-4 \pm 2.100-5$

$9.738-5 \pm 6.583-6$

$3.098-5 \pm 2.500-6$

$1.062-5 \pm 1.076-6$

$2.735-6 \pm 3.320-7$
Fig. F-3. 1 ssion chamber response to a ${ }^{5} \mathrm{Cf}$ source in watex.
(3)

-

33.3

50.7

40.7

50.7

36.9

36.8

19.1

15.8

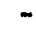

13.4

37.6

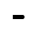

7.2 


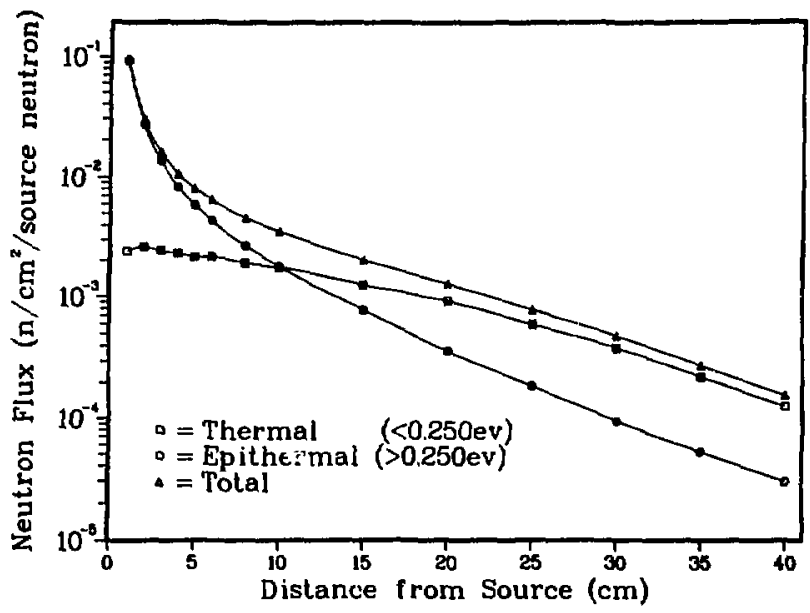

Fig. F-4.

Thermal and eptthermal neutron flux at var" "is distances in water from a 252 Cf source.

fission chamber in water was accomplished exper1mentally. Counts were collected from a bare and a cadmium-wrapped fission chamber inmersed in water for various californtum source-detector separations. The ratio of cadmium-to-bare-detector counts is plotted in Fig. F-5. Increasing the separation hetween source and detector provides more thermalization of neutrons and produces a lower ratio of epicadmium-to-total counts. Typically, the detector will be separated from an actual spent-fuel assembly by about $5 \mathrm{~cm}$ or greater. The response of a cadmium-wrapped fission chamber will be between 1 and 2 of the bare detector response to a fission spectrum for sourcedetector separations of 5-15 cm.

III. FUEL MATERIAL INVENTORY

Fuel materials are avallable to simulate experimentally both PWR and bolling-water-reactor (BWR) fuel assemblies. PWR assemblies have a uniform fuel loading, are larger thas BNR assemblies, and their lootope inventories can be calculated as a function of exposure using the CINDER code (App. D). The smaller size of BWR assemblies, compared with PWR, should enable a more uniform interrogation of their matrix. However, the nonuniform fissile loading and the addition of burnable poison rods in the BWR fuel make this measurement more difficult and lefs accurate compared to PWR measurements. The present lack of a suitable method to determine BWR isotope inventory as a function of exposure poses a problem in attempting to construct experimental configurations that are representative of various exposure levels. Therefore, experimental work is focused currently on the PWR measurement problem.

The materials currently available for constructing FWR measurement geometries are listed in Table F-III. A schematic drawing of the 15 by 15 PWR fuel assembly skeleton is shown in Fig. F-6, and a plcture of the assembly, loaded with fuel and being lowered into the large cylindrlcal tank, is shown in Fig. F-7. Fuel cladding tubes for BWR and PWR fuel are available to permit experimental rods to be filled with various materials, so that a variety of test configurations can be constructed. Both depleted and 3.38 enriched $\mathrm{NO}_{2}$ fuel pellets are available to construct fuel rods. A californium source can be inserted at the center of two special rads built using depleted and enriched pellets. These source-fuel rods allow detector response measurements to be obtained corresponding to neutron emission from fuel at various rod positions in the assembly matrix. Hatrix sensitivity effects for passive and active neutron measurements are determined uning these rode.

The Inventory of available Bin fuel component. is listed in Table F-IV. An additional 100 alxedoxide BWR rode will be available soon. The atr 


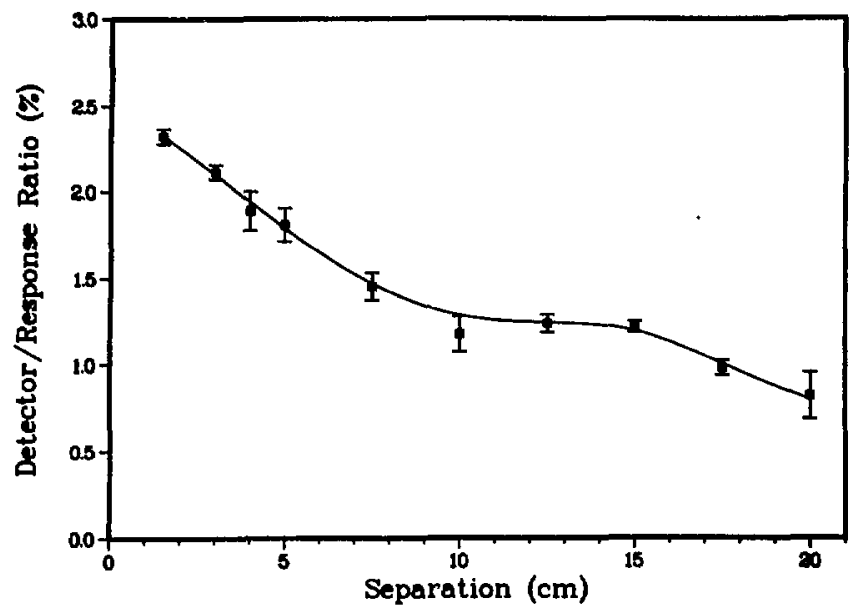

F1g. F-5.

Fission chamber reaponse ratio (cadmiumcovered/bare) for a $252 \mathrm{Cr}$ vource in a water environment.

Fig. F-6.

15 by 15 PWR assembly avallable for experiments.
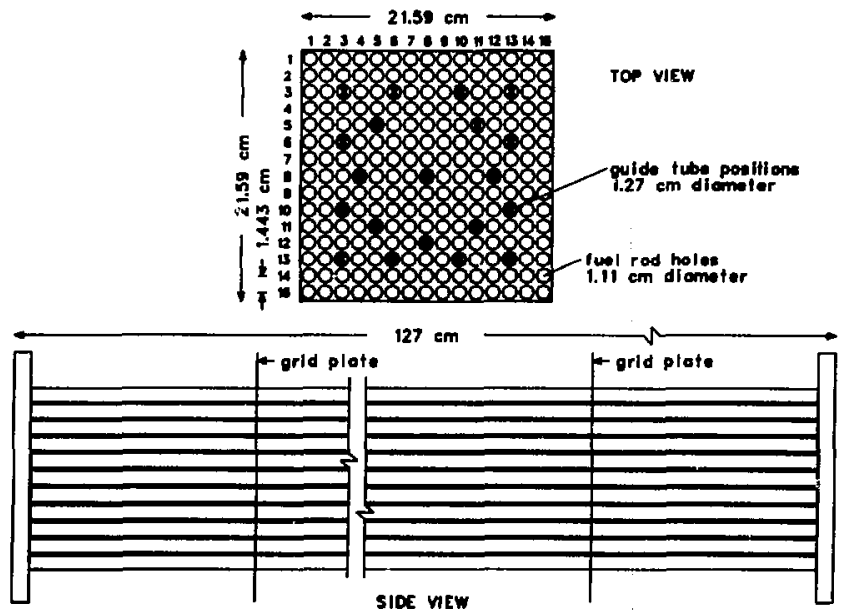

rods currently available for neasurement are characteristic of asuemblien used in older generation reactors. Experimental work using the current BNR Inventory will begin following completion of neasurement. with the PWR component:

IV. PWR FUE ASSERLY MLASURMISTSS

Approach-to-critical meanurements are required to ensure that the 15 by 15 PWR-type fuel assembly can be safely inmeraed in water for apecified gecoetries and fiestle material loadings. Two experimental geonetries were constructed, the approach-to-criticel mosurements were conpleted, and approval was granted by the criticality safety comittee to proceed with experimentu. The first geometry approved for experiments is the large cylindrlcal tank sown in FIg. F-7 using the 15 by 15 PWR astembly. The second spproved geometry, also shown in Fig. F-7, is a rectangular tank providing a clone fit to the 15 by 15 FWR assembly. Th1. rectangular tank is eurrounded by a table permitting various materiale to be stacked around the assembly.

The approach-to-critical procedure consiat: of securing the PWR asseably, with no fuel rode, in the masurement geometry of intereat and then filling with water. A ${ }^{252} \mathrm{Cf}$ neutron source 1 s 
TRELE PEII

FAR FUG, MATERIATS AND CONPONENTS

\section{Tuel nsmenblies}

Array wize
ruel positions
Gulde tube positions
Outelde dimension
Asuembly helght
Rod pitch (center-center)
skeleton 1
skeleton $\$ 2$

15 by 15

204

21

$21.59 \mathrm{~cm}$

$127.00 \mathrm{~cm}$

$1.42 \mathrm{~cm}$

Stainless steel guide tubes

zircaloy guide tubes

\section{Fuel Rod Inventory}

$\mathrm{UO}_{2}$ Ceramic Fuel

14 aluminum clad 3.2 wt 235 v

189 zircaloy clad 3.19 wt $235 \mathrm{u}$

15 zircaloy ciad 3.3 wt $235 \mathrm{U}$

10 Zircaloy clad 0.7 wt $235 \mathrm{u}$ (natural)

204 Iircaloy clad 0.2 wt 235 (depleted)

Mixed Oxide Fuel

530 Zircaloy clad rods containing $\mathrm{PuO}_{2}$

(258) mixed with $\mathrm{UO}_{2}$

Plutoniun Isotopic Cosposition $(10 / 1 / 80)$

\begin{tabular}{lc} 
Isotope & $\begin{array}{c}\text { Range } \\
\text { (wt) }\end{array}$ \\
\hline${ }^{238_{\mathrm{Pu}}}$ & $0.478-1.03$ \\
$239 \mathrm{Pu}$ & $73.193-76.512$ \\
$240 \mathrm{Pu}$ & $15.046-18.668$ \\
$241_{\mathrm{Pu}}$ & $4.111-6.241$ \\
$242 \mathrm{Pu}$ & $1.452-1.975$
\end{tabular}

located in one of the fuel-asgembly guide tubes, and two neutron detectora are located in the water region outside the assembly. The mesurement procedure consists of collecting an initial count, $C_{0}$, with no fuel, followed by additional counts, $C_{1}$, as fuel rods are added to the asmembly. The ratio of counts, $c_{0} / c_{1}$, is plotted vs fuel rod loading and used to deteraine the number of rods that can be added to the assembly at each atep of the approach-to-critical meanurement. When the array is full, the ratio $c_{0} / c_{1}$ provides an experfinental value for fuel-ansembly multiplication. A plot of the approach-to-critical data collected for the sall rectangular tank, with lead and polyethylene surrounding the fuel, is

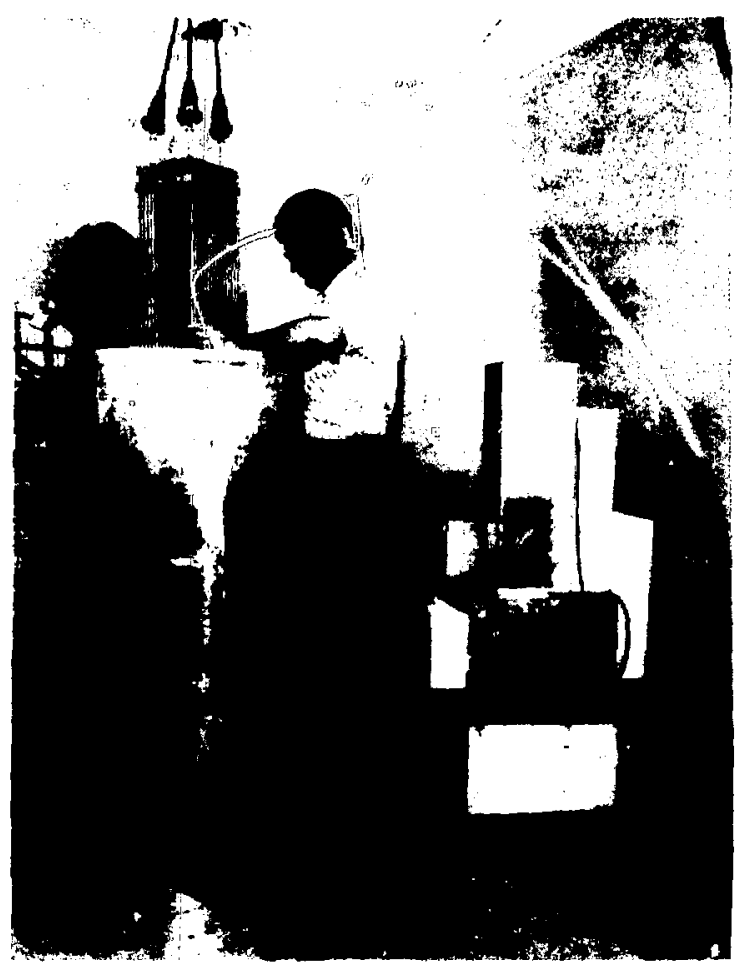

Fig. F-7.

Rectangular and cylindrical fuel ansembly measurement tanks. A 15 by 15 PWR fuel assembly is being lowered into the cylindrical tank.

-hown in Fig. F-a. The multiplication for thim geometry was determined to be between 8 and 10 . The curve in Fig. F-8 becomes leat ateop as wore fuel roda are added, Indicating a much larger quantity of fuel would be required to reach a critical (unmafe) utate.

Sensitivity of neutron measurementa to changes In the ${ }^{235} \mathrm{U}$ loading of one fuel pin placed at various locations in the 15 by 15 PWR fuel ansembly inorged in water was deterained exporimentally. A ${ }^{252}$ ce neution source, centered $4 \mathrm{~cm}$ from the aseembly edge and positioned at the fuel miplane, induced fiestons in the fuel. A 4-atn ${ }^{3}$ He counter. centered $3 \mathrm{em}$ from the anecubly on the side opposite the source, detected neutrons produced from the source and from fiselone in the fuel. The soneitivity study consisted of comparing count rates from the anembly before and efter one of the 2043.2 enriched fuel rodu we repleced with a natural (0.73 enrlched) rod. The matrix positione correoponding to rod locations are lieted in 


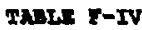

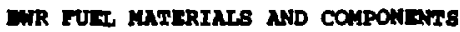

Fuel Arembly

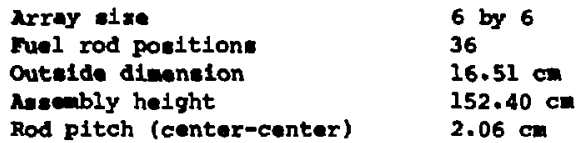

Euel Bod Inventory

$\mathrm{UO}_{2}$ Cerami: Fuel

36 zircaloy clad 2.34 wt $235 \mathrm{v}$

6 Eircaloy clad 1.77 wt $235 \mathrm{u}$

Mixed Oxide Fuel

36 zirceloy clad 2.3 wte $\mathrm{PuO}_{2}$

Plutoniun Isotopic Composition

\begin{tabular}{lr} 
Ieotope & wt \\
\hline${ }_{238} \mathrm{Pu}$ & 0.28 \\
${ }^{239} \mathrm{Pu}$ & 75.52 \\
${ }^{240} \mathrm{Pu}$ & 18.12 \\
${ }^{241} \mathrm{Pu}$ & 5.00 \\
$242 \mathrm{Pu}$ & 1.09
\end{tabular}

Fig. F-6. Colum and row positions are along the top and side of the asembly, raspectively, and range from 1-15. The count-rate difference for rod aubetitution along column 7 is shown in Fig. -9. The ${ }^{252} \mathrm{cf}$ source wae adjacent to pin 8 in row 15. The mensitivity meanuremente indscate a decrease in the ${ }^{235} \mathrm{u}$ loading of one rod from 3.2-0.74 can be reliably detected. The average count-rate difference along colum 7 1. $0.93 \pm$ 0.174 . Nearly all rode along the colum produced nearly the sare count-rate difference, indicating that the ansitivity to change in 235 y loading 18 Independent of the atrix location. The exception to this obeervation occurs for fuel rods adjacent to the naution source. Thene rods produce algnificantly larger count-rate difference than the average, indicating an increaned senaltivity to changen in ${ }^{235} \mathrm{U}$ loading. This same trend was obeerved for column: $1-6$; however, the average count-rate difference is maller, but

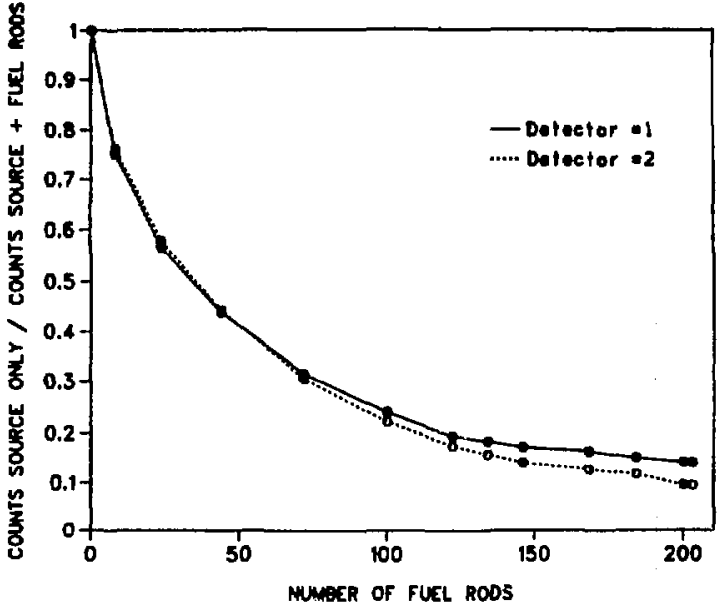

Fig. $F-8$. Approach-to-critical data for the rectangular tank.

still observable, for fuel rod columns farther from the source and detector.

V. DXPERIMEATAL GOALS AND MEASUREMENT OBJDCTIVES Ruture measurements are planned with fission chambere encased in water-tight polyethylene ulevev. wxperiments will first concentrate on reducing the sensitivity of detector responses to the araembly matrix. Data will be collected for various neutron source positions with different number of detectors at various locations around the ansembly. Figure F-10 is a picture of the fisetion chamber and ${ }^{252} \mathrm{cf}$ source-positioning jig to be used for these atudies. The j1g 18 shown positioned on the top of the 15 by 15 Fir-type fuel ascambly with the polyethylene detector sleeve in horizontal position. This jig and fuel assembly will be firmly secured in the large cylinarical water tank for measurements and 1 s show here freeatanding for vieual clarity. Results of the sensitivity studies will be used to guide design of a neutron talloring and dietribution region for a 252 cf source and to specify the number of detectors and their position: around the asembly.

The primary objective of the experimental program is to develop and teat the capacity of various mengurement geonetries to provida iasiute 
FũL colin' position 7

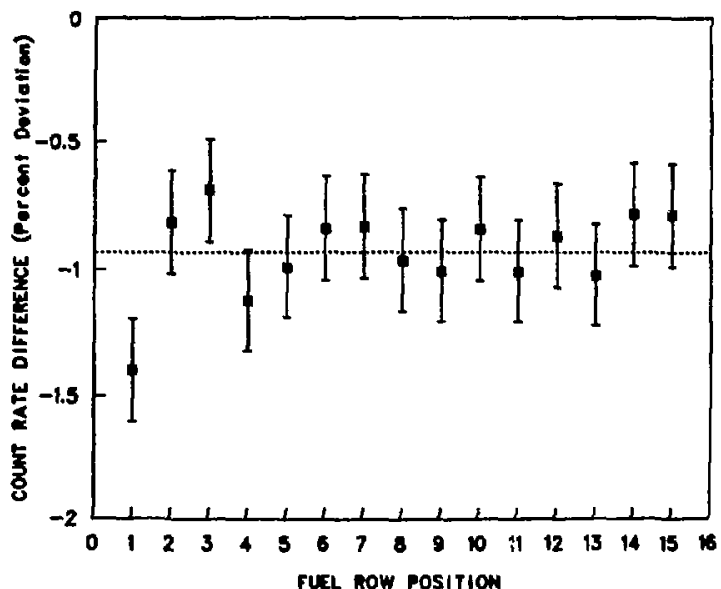

Fig. F-9.

Sensitivity of active neutron measurements to fuel rod substitution.

spent-fuel measurements over a representative range of exposures and cooling times. Preliminary measurements to validate the Monte carlo code have been completed. Initial eensitivity measurements indicate that the measurement goals may be achieved with proper design. Additional detailed sensitivity measurenents will be completed to determine a design that is insensitive to the assembly matrix.

Experiments are planned on $P W R$ and $B W R$ assemblies using combinations of $\mathrm{NO}_{2}$ and $\mathrm{PuO}_{2}$ materials to simulate fuel buxnupg up to $50 \mathrm{GWd} / \mathrm{tU}$. Measurements over this burnup range will be collected and evaluated in terms of developing calibration curves relating neutron measurenents to effective figsile content and fuel assembly exposure. Contributions to the steady-state neutron count rate from plutonium and uranium fissions will be studied in an attempt to determine the plutonium/uranium ratio. Field measurements to test the active neutron method will follow once a measurement system has been developed, constructed, and tested at Los Mlanos.

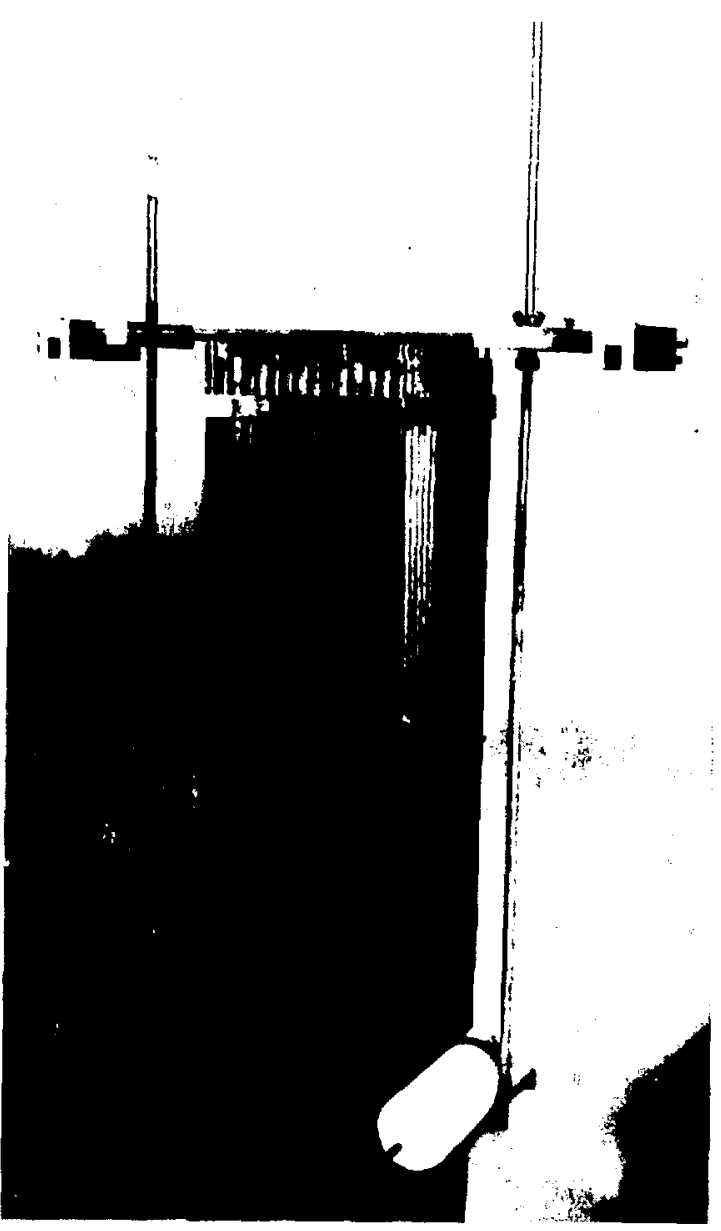

Fig. $E-10$.

Positioning jig containing a polyethylene-encased fission chamber and a $252 \mathrm{cf}$ holding rod located on top of a 15 by 15 pwR-type fuel assembly. 